$27 / 4^{2}+3$

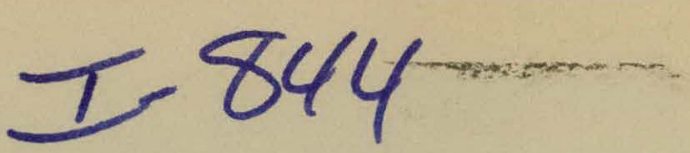
SANDIA REPORT SAND79-0274 • Unlimited Release rinted November 1981

\title{
Basic Data Report for Drillhole WIPP 15 (Waste Isolation Pilot Plant-WIPP)
}

Sandia National Laboratories, University of New Mexico

Prepared by

Sandia National Laboratories

Albuquerque, New Mexico 87185 and Livermore, California 94550

for the United States Department of Energy

under Contract DE-ACO4-76DP00789

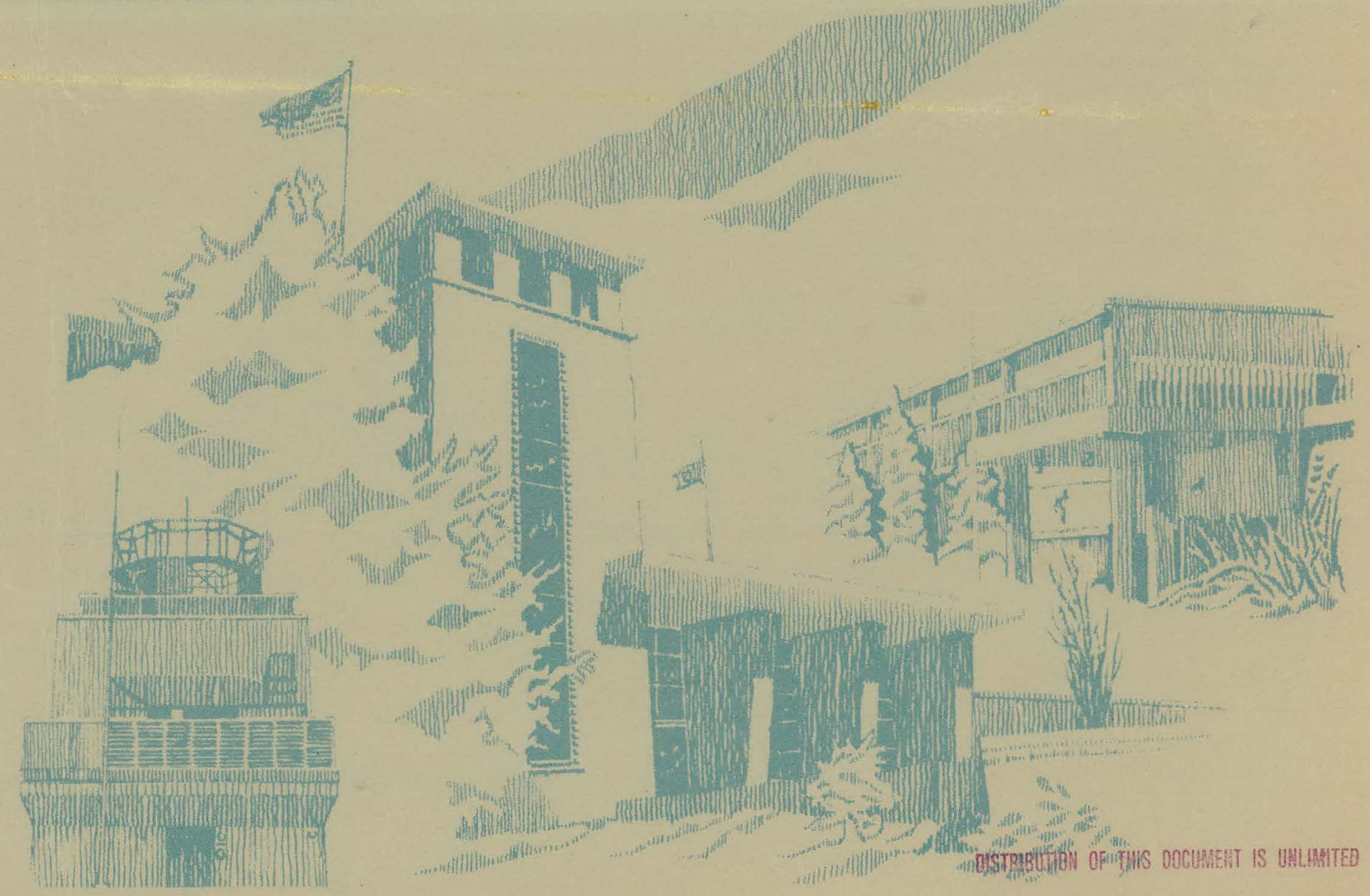




\section{DISCLAIMER}

This report was prepared as an account of work sponsored by an agency of the United States Government. Neither the United States Government nor any agency Thereof, nor any of their employees, makes any warranty, express or implied, or assumes any legal liability or responsibility for the accuracy, completeness, or usefulness of any information, apparatus, product, or process disclosed, or represents that its use would not infringe privately owned rights. Reference herein to any specific commercial product, process, or service by trade name, trademark, manufacturer, or otherwise does not necessarily constitute or imply its endorsement, recommendation, or favoring by the United States Government or any agency thereof. The views and opinions of authors expressed herein do not necessarily state or reflect those of the United States Government or any agency thereof. 


\section{DISCLAIMER}

Portions of this document may be illegible in electronic image products. Images are produced from the best available original document. 
Issued by Sandia National Laboratories, operated for the United States Department of Energy by Sandia Corporation.

NOTICE: This report was prepared as an account of work sponsored by an agency of the United States Government. Neither the United States Government nor any agency thereof, nor any of their employees, nor any of their contractors, subcontractors, or their employees, makes any warranty, express or implied, or assumes any legal liability or responsibility for the accuracy, completeness, or usefulness of any information, apparatus, product, or procompleteness, or usefulness of any information, apparatus, product, or pro-
cess disclosed, or represents that its use would not infringe privately owned cess disclosed, or represents that its use would not infringe privately owned
rights. Reference herein to any specific commercial product, process, or service by trade name, trademark, manufacturer, or otherwise, does not necessarily constitute or imply its endorsement, recommendation, or favoring by the United States Government, any agency thereof or any of their contractors or subcontractors. The views and opinions expresed herein do not necessarily state or reflect those of the United States Government, any agency thereof or any of their contractors or subcontractors.

Printed in the United States of America Availahle frnm

National Technical Information Service

U.S. Department of Commerce

5285 Port Royal Road

Springfield, VA 22161

NTIS price codes

Printed copy: $\$ 6.00$

Microfiche copy: $\$ 3.00$ 


\section{Basic Data Report}

for

Drillhole

WIPP 15

SAND79-0274

\section{Compiled by}

Sandia National Laboratories

(Division 4511)

and

University of New Mexico

(Department of Geology)

This biook was prepared as an account ol work sponsored by an ogency of the United Stetes Government. Neither the United States Government nor any agency thereof, nor any of their emplovees, makes any

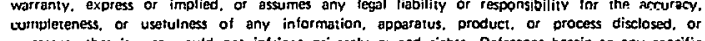

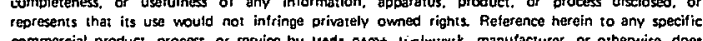

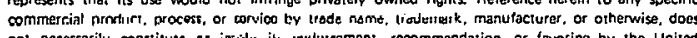
not nececcarity constitute or impily its efturussement, recommendation, or favoring by the United

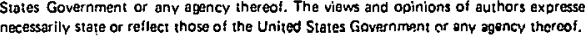


$2.0 \quad$ INTRODUCTION $\ldots \ldots \ldots \ldots \ldots \ldots \ldots \ldots \ldots \ldots \ldots \ldots \ldots \ldots$

2.1 The Purpose of WIPP $\ldots \ldots \ldots \ldots \ldots \ldots \ldots \ldots \ldots \ldots \ldots \ldots \ldots \ldots \ldots$

2.2 The Purpose of WIPP $15 \ldots \ldots \ldots \ldots \ldots \ldots \ldots \ldots \ldots \ldots$

3.0 GEOLOGICAL DATA

by R. Y. Anderson and S. J. Anderson, UNM :...... 4

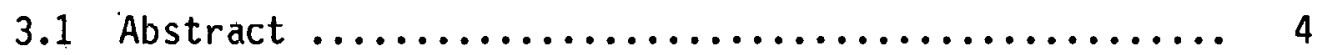

3.2 Introduction $\ldots \ldots \ldots \ldots \ldots \ldots \ldots \ldots \ldots \ldots \ldots \ldots \ldots \ldots \ldots \ldots \ldots$

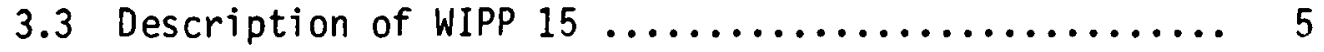

4.0 HYOROLOGICAL DATA

by D. D. Gonzalez ..................... 24

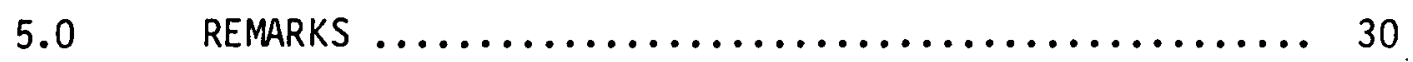

$6.0 \quad$ BIBLIOGRAPHY $\ldots \ldots \ldots \ldots \ldots \ldots \ldots \ldots \ldots \ldots \ldots \ldots \ldots \ldots \ldots$

APPENDICES

A. 1. Report of Quaternary Fossils

by J. P. Bradbury, USGS

2. Radiocarbon Age Determination

Report of Analytical Work by Krueger Enterprises, Inc.

B. Drilling and Testing Plan

by R. D. Statler, 1133

C. Hole History

compiled by R. D. Statler, 1133, and.P. D. Seward, 1135

D. Logs

compiled by S-E. Shaffer, 4511 


\subsection{ABSTRACT}

WIPP 15 is a borehole drilled in March, 1978, in section 18, T.23S., R. 35E. of south-central Lea County. The purpose of WIPP 15 was to examine fill in San Simon Sink in order to extract climatic information and to attempt to date the collapse of the sink. The borehole was cored to total depth (810.5 feet) and encountered, from top to bottom, Quaternary calcareous clay, marl and sand, and claystones and siltstones of the Triassic Santa Rosa Formation (?). Neutron and gamma ray geophysical logs were run to measure density and radioactivity.

The sink has about 547 feet of Quaternary fill indicating subsidence and deposition. Diatomaceous beds exposed on the sink margin yielded samples dated by ${ }^{14} \mathrm{C}$ at $20,570 \pm 540$ years $B P$ and greater than 32,000 years BP; these beds are believed stratigraphically equivalent to diatomaceous beds at 153-266 feet depth in the core. Aquatic fauna and flora from the upper 98 feet of core indicate a pluvial period (probably Tahokan) followed by an arid or very arid time before the present climate was established.

Aquifer pump tests performed in the Quaternary sands and clays show transmissivities to be as high as 600 feet squared per day. As the water quality was good, the borehole was released to the lessee as a potential water well. 


\subsection{INTRODUCTION}

The introduction describes background information on the Waste Isolation Pilot Plant (WIPP) and the investigations involving WIPP 15.

\subsection{The Purpose of WIPP}

The purpose of the WIPP is distinct from that of several other projects for the disposal of radioactive waste. The WIPP is planned to demonstrate disposal technology for the transuranic (TRU) waste resulting from this nation's defense programs of over 30 years. After a period (5 years) of limited (pilot) operation, it is anticipated that the WIPP will be converted to a full-scale repository for permanent disposal of defense TRU waste. The WIPP plans also include an underground research facility to examine, on a large scale, the interactions between bedded salt and high-level radioactive defense waste with its resultant thermal and radiation fluxes. There is no $\mathrm{plan}$ at this time to dispose of high-level waste or spent fuel in the WIPP.

Additional information on the WIPP and characterization of the WIPP site may be found in Powers, et. al. (1978).

\subsection{The Purpose of WIPP 15}

During investigations of dissolution of evaporites in southeastern New Mexico, it was apparent that more information on the climate in the local area during the Pleistocene would be quite useful. Pleistocene deposits were thought to be most complete in some of the playas or lakes where deposition was probably continuous regardless of the climatic 
fluctuations. Likely targets included Laguna Grande de la Sal, the West Texas salt flat graben, and San Simon Sink/Swale. Of these targets, San Simon Sink and Swale seemed the most appropriate; the area was believed to have suffered dissolution over a period of time, additional collapse had occurred during historic times, and marginal lake beds showed an abundant flora and fauna. Laguna Grande was less well known, and the extreme salinity may have distorted the record of climate indicators. The West Texas salt flats were felt to be a very good target, but the area is further from the WIPP site.

Two drilling locations were chosen: WIPP 15 was located in the bottom of San Simon Sink and WIPP 17 was located north of the Sink near the axis of the Swale. Two locations were chosen in the event the information from WIPP 15 needed supplementing. However, the information from WIPP 15 was believed adequate, and plans for drilling WIPP 17 were abandoned. WIPP 15 was drilled, then, in order to investigate the Quaternary stratigraphy and the history of climatic changes and structural events that resulted in Pleistocene lake(s) in San Simon Sink. It was believed that the Sink resulted from dissolution of the underlying evaporites, and it was thought that the borehole might provide some evidence of the units in which dissolution had occurred. 


\subsection{GEOLOGIC DATA FOR BOREHOLE WIPP 15}

by

Roger Y. Anderson ${ }^{1}$ and Sandra J. Anderson 1

\subsection{Abstract}

WIPP-15 was drilled in San Simon Sink, Lea County, New Mexico, to determine Quaternary stratigraphy and the history of climatic changes and structural events that resulted in Pleistocene lake(s) in the sink.

The borehole encountered, from top to bottom, Quaternary calcareous clay, marl, and sand, and claystones and siltstones of the Triassic Santa Rosa Formation (?). Total depth of borehole is 810.5 feet.

Neutron and gamma ray geophysical logs were run to measure density and radioactivity.

rossils from the upper 30 meters of core refiect Pleistocene environmental and climatic conditions. Radiocarbon dates on fossils from diatomaceous beds believed stratigraphically equivalent to the lower clay unit in the core give dates of 20,570 years B. P. and greater than 32,000 years B.P.

The timing of collapse in San Simon Sink, as revealed by stratigraphy of the sink hole fill, will add to the geologic history of the WIPP site and facilitate safety assessment for storage of radioactive wastes.

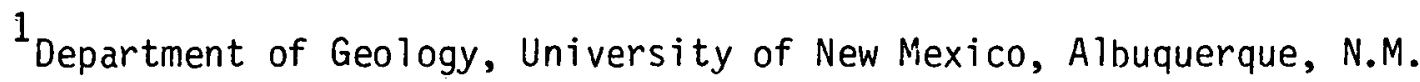




\subsection{Introduction}

Borehole WIPP-15 is one of a series of exploratory boreholes drilled by Sandia National Laboratories on behalf of the WIPP Project Office of the DOE.

WIPP-15 was cored to obtain paleoclimatic data from the sub-surface at San Simon Sink and to examine the relationship between surficial features and deposits and subsurface structure.

\subsection{Description of WIPP-15}

WIPP 15 is located in San Simon Sink, Lea Co., New Mexico, 1793 feet from the west line, 2426 feet from the north line (NW1/4SE1/4SW1/4) of Section 18, T.23S., R.35E. (Fig. 1). The borehole was drilled to a depth of 810.5 feet from an elevation of 3269.34 feet above sea level. Drilling started March 8, 1978, and finished April 4, 1978.

The first 9.67 feet were drilled with air using a split sample spoon. A $43 / 4$ inch $\times 23 / 4$ inch core bit and air were used to 13.25 feet where drilling with mud began. A 4 inch rock bit was used from 29.35 feet to 566.2 feet and a tungsten carbide bit was used to complete the hole to the total depth of 810.5 feet. The hole was opened to $61 / 8$ inch to a depth of 592 feet. Blank casing was installed from 0-445 feet, slotted casing from 445 feet to 540 feet, and blank casing again from 540-555 feet. 


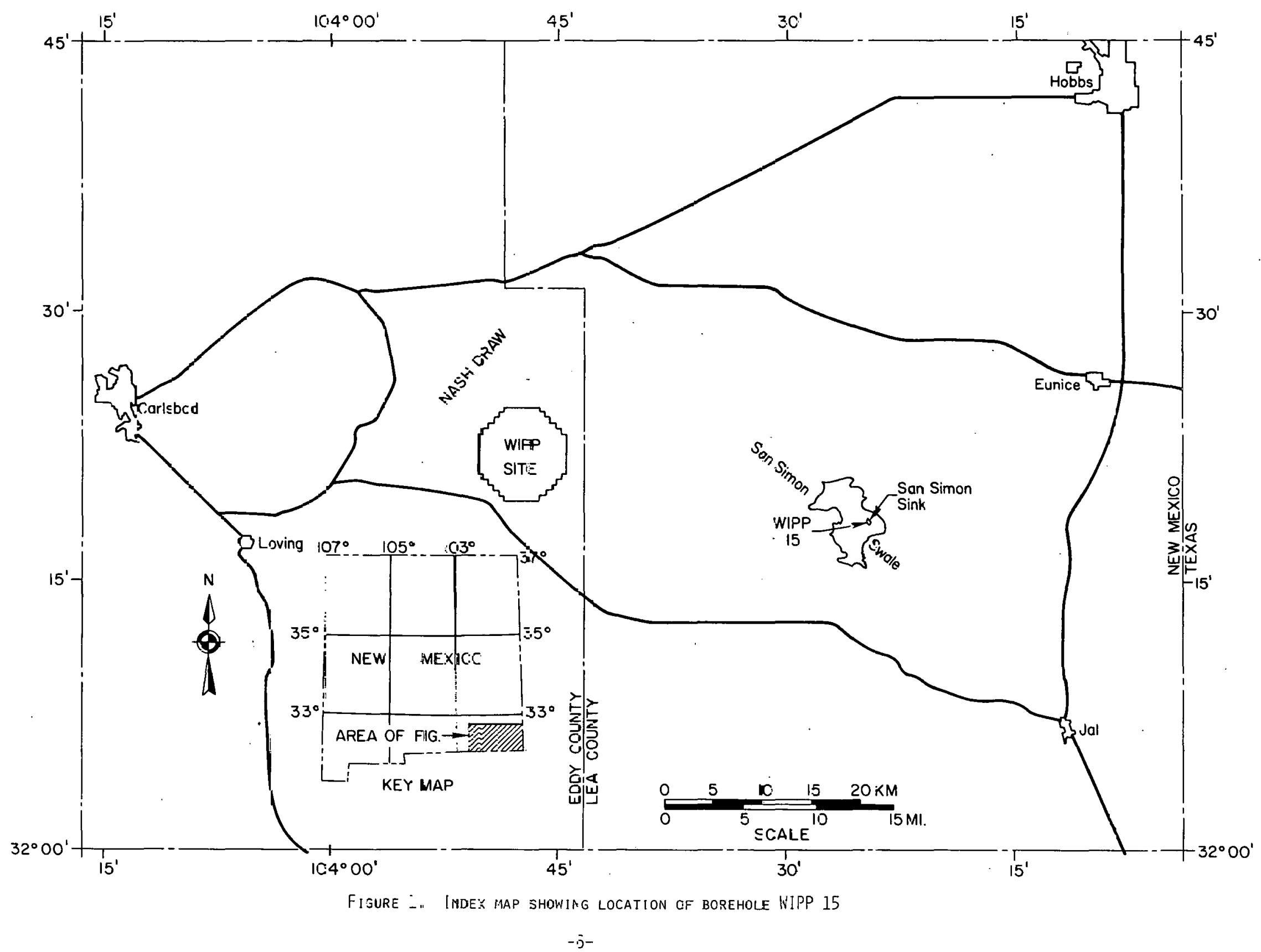


Gamma ray and neutron logs were run by USGS at 493.2 feet and at total depth, 810.5 feet.

Borehole WIPP 15A was drilled April 4 and 5, 1978, nine feet from WIPP 15 to recover core lost from 29-75 feet. A 4 inch hole was drilled with air from 0-29 feet. Core was recovered from 34.2-61.3 feet (total depth) using mud and a wire line core barrel with split inner barrel and a 3.95 inch diamiond bit.

A detailed history of borehole WIPP 15 and WIPP 15A was compiled by Fenix and Scisson, Inc. (Appendix $C$ ) and is summarized in Table 1.

Recovered core was examined and logged at the drill site by Roger $Y$. Anderson.

Borehole WIPP 15 penetrated 547 feet of Quaternary clay, sand, and marl. The upper 160 feet of section are generally light gray, very calcareous, gypsiferous, and contain organic debris. The texture varies from sandy clay to clayey sand. Clay and silt which are predominantly calcareous are termed marl. Mottled brown calcareous and light blue gray clay grades into olive gray clay at 213 feet.

These calcareous clays are underlain by 321 feet of reddish brown sand containing pebbles of Triassic sandstone and caliche in the upper part. The sand is of ten calcareous, partially inundated with calcareous cement in places, and of ten silty and/or clayey. Clay and silt interbeds are especially common in the upper 150 feet of the sand unit.

The Quaternary sediments rest uncomformably on 230 feet of the Triassic Chinle Formation. The Chinle is a dark red-brown laminated claystone and siltstone. Minor faults, fractures, breccia zones, and bedding dips of $10-15^{\circ}$ are common. Five feet of gray-purple conglomerate occur at 746 feet. 
Two thin sections of the Triassic sandstone in the core show ironstained quartz, feldspar, and lithic framework grains with an estimated $5-10 \%$ cherty cement. Calcite is replacing both cement and framework grains and is the sole consitituent of the rock in places. Quartz grains are strained or composite and may exhibit crystal faces as the result of silica overgrowths. Feldspars are degraded in some cases and fresh in others. Some have been completely replaced with calcite. Lithic grains are predominantly chert and sedimentary rock fragments. Clay coatings are common.

The hole ends in a light gray sandstone which may be part of the Triassic Santa Rosa Formation.

A stratigraphic-summary of the borehole is presented in Table 2. Geologic and geophysical logs are presented in Figure 2. Table 3 is a detailed lithologic $\log$ and Figure 3 shows the stratigraphic details for horehnle WTPP 1.5.

The location of WIPP 15, the measurements of depth in the borehole, and the original logs of the core are in English units of measure. The following conversion factors will give metric units.

$\begin{array}{ccc}\text { Multiply English Units } & \text { by } & \text { To obtain metric unit } \\ \begin{array}{c}\text { inch (in) } \\ \text { inch (in) }\end{array} & 2.54 & \text { centimeter (cm) } \\ \text { foot (ft) } & 25.4 & \text { millimeter (mm) }\end{array}$




\subsection{Fossil Occurrences}

Aquatic snails, ostracods, diatoms, and plants occur in the calcareous clay and marl of the upper 98 feet (30 meters) of core (Fig. 4) and fossil pollen also occurs between 215 and 217 feet. For complete description, identification, and precise stratigraphic location of fossils, pollen analysis and stratigraphy in the core and surrounding area, and environmental interpretations, see the Preliminary Report on Referred Fossils (Appendix A).

Triassic palynomorphs, similar to those observed elsewhere by Dunay and Traverse (1971) in the Chinle Formation, were recovered from the core by Roger Y. Anderson at a depth of 705 feet.

\subsection{Radiocarbon Data}

Two samples from diatomite beds believed stratigraphically equivalent to the lower clay unit (153-226 feet) of WIPP 15 were collected on the north side of San Simon Sink, Sec. 18, T.23S., R.35E., Lea Co., NM. These samples were dated with radiocarbon methods in the Geochron Laboratories Divison of Krueger Enterprises, Inc., Cambridge, Massachusetts in December, 1978 (Appendix A).

A date of $20,570 \pm 540 \mathrm{C}-14$ years $\mathrm{BP}$ was determined on the gastropod shell sample (Physa sp., Lymnaea sp., Helisoma sp.). The sample of charophyte oogonia (Chara sp.) from the same stratigraphic unit was dated at greater than $32,000 \mathrm{C}-14$ years BP. 


\subsection{Brief History of Geologic Events}

1. An exposure of Triassic Chinle siltstone and shale was subjected to subsidence and the area filled with about 320 feet of quartzose, well-sorted medium to fine-grained sand.

2. Caliche and Triassic sandstone pebbles up to several centimeters in diameter were shed into the area along with the sand beginning about 150 feet above the base of the sand sequence.

3. Episodes of increased clay deposition alternated with sand deposition, culminating in a 40-foot thick clay bed 350 feet above the base of the sand section. This unit is calcareous at the base, contains a Pleistocene "pluvial" pollen flora (Appendix A), and is believed equivalent to calcareous diatomite marl dated by radiocarbon analysis (see above).

4. Sand was deposited over the 40 -foot thick clay bed; the sand was succeeded by an influx of reworked diatomaceous marl from the margins of the swale.

5. The upper 39 feet of the sequence contains calcareous organicrich clay and playa sediments associated with collapse of San Simon Sink to form the present surface expression. 


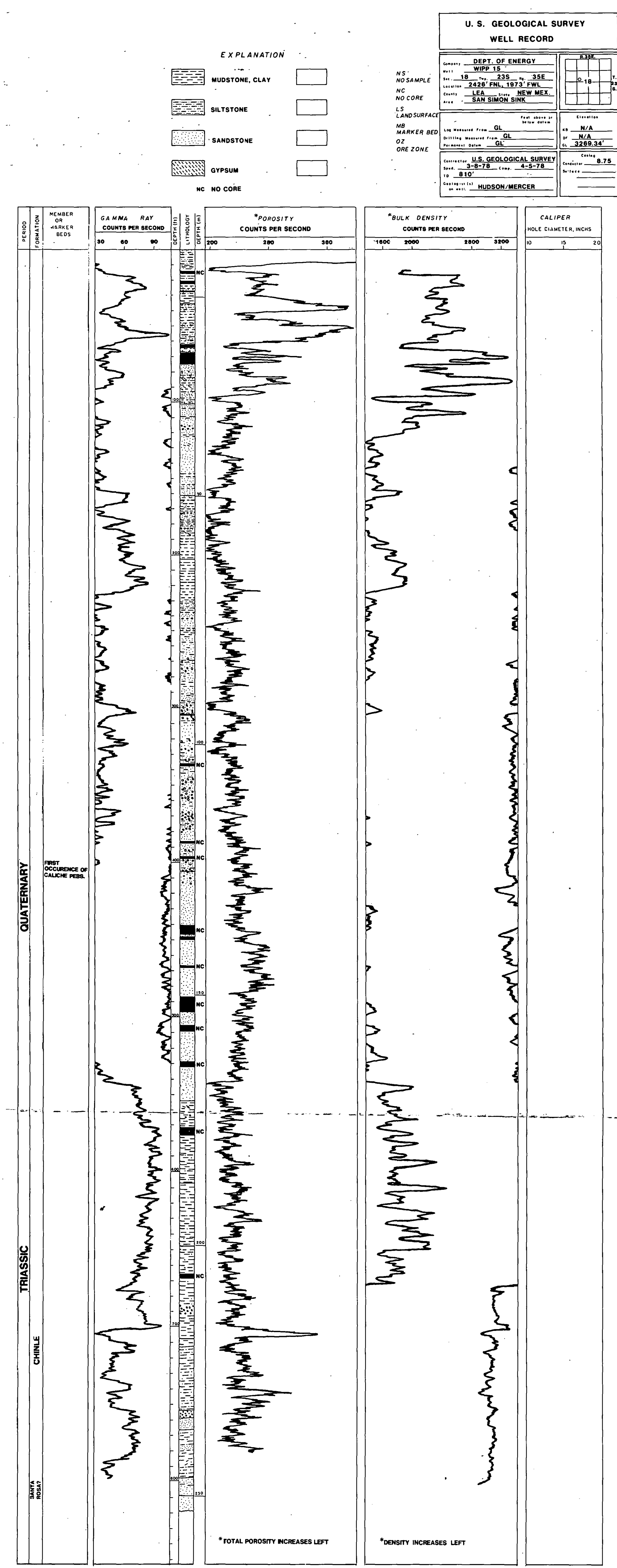

$-11-$ 
Fig. 3. Detailed stratigraphic section

for borehole WIPP 15
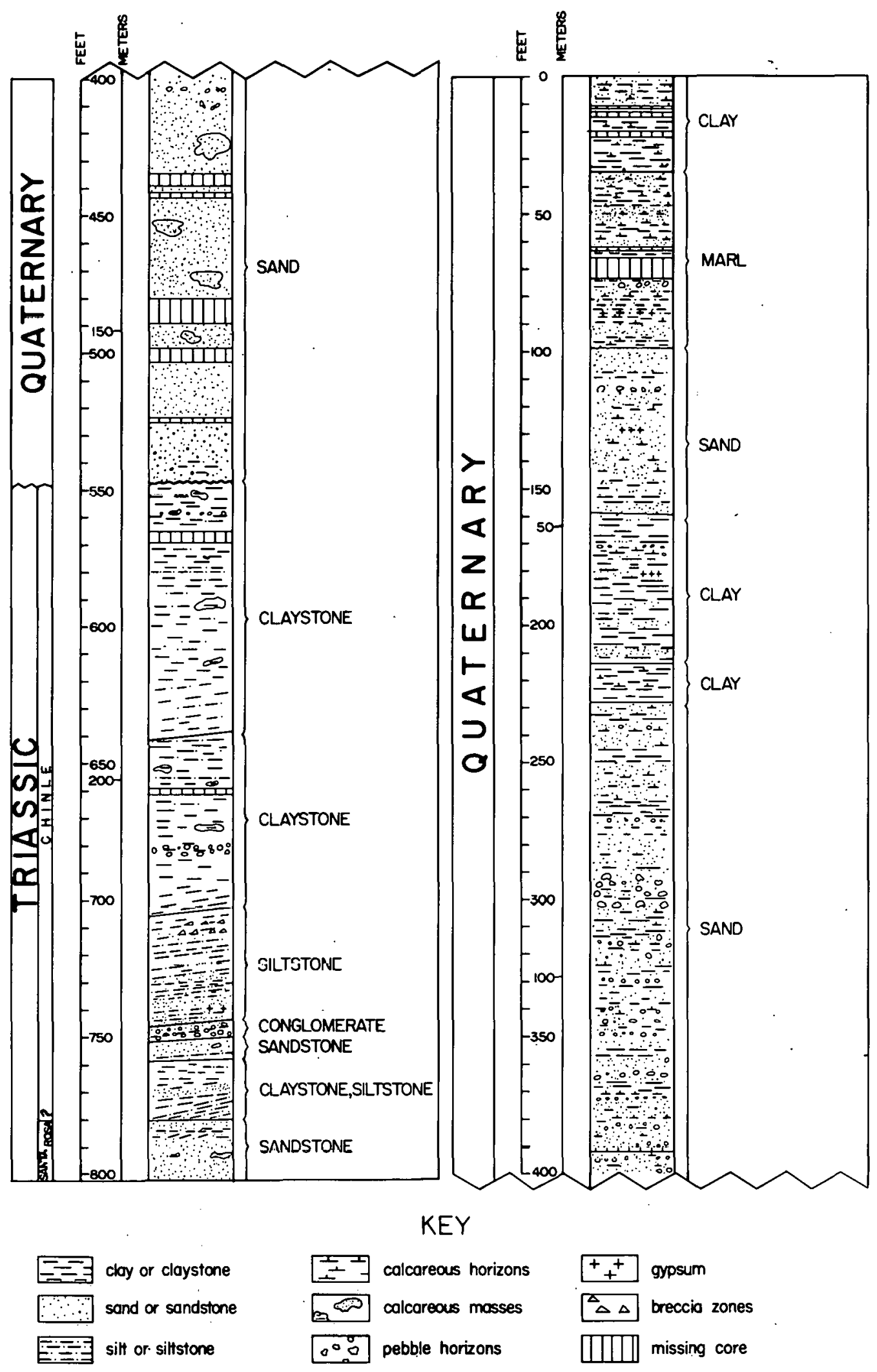

SAN SIMON SINK

(WIPP-15) 


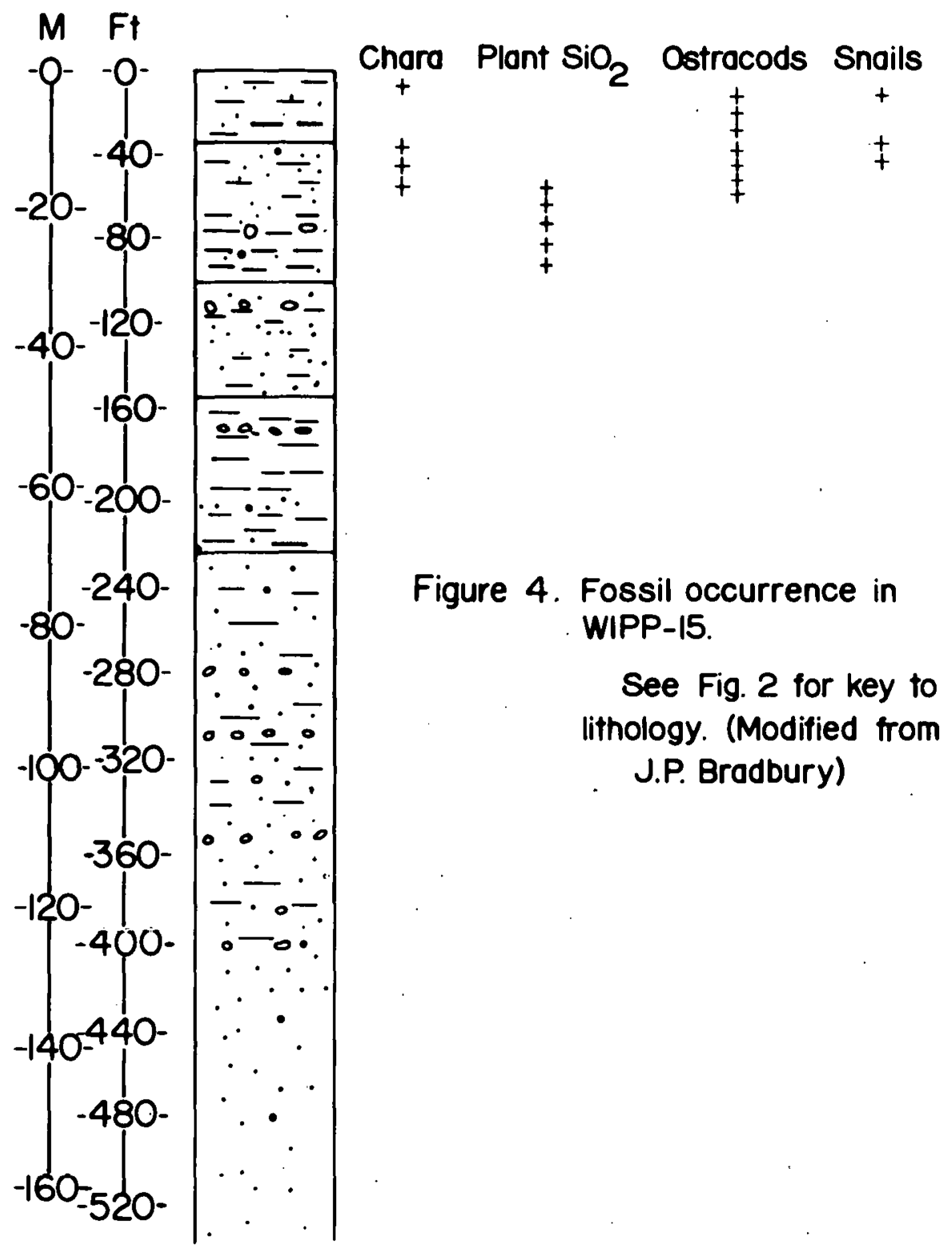


Table 1

Abridged History of Borehole WIPP 15

(From WIPP \#15 Field Engineering Summary)

\begin{tabular}{|c|c|c|c|c|c|}
\hline Core No. & \multicolumn{2}{|c|}{ Interval } & Cored & Recovered & \% Recovery \\
\hline 1 & $0^{\prime \prime}$ & $-12^{\prime \prime}$ & $12^{\prime \prime}$ & $12^{\prime \prime}$ & 100 \\
\hline 2 & $12 "$ & $-\quad 26^{\prime \prime}$ & $14^{\prime \prime}$ & 121 & 86 \\
\hline 3 & $26^{\prime \prime}$ & - $34^{\prime \prime}$ & 8" & 6" & 75 \\
\hline 4 & $34^{\prime \prime}$ & $-48^{\prime \prime}$ & $14 "$ & $8^{\prime \prime}$ & 57 \\
\hline 5 & $48^{\prime \prime}$ & $-60^{\prime \prime}$ & $12^{\prime \prime}$ & $9^{\prime \prime}$ & 75 \\
\hline 6 & $60 "$ & - $66^{\prime \prime}$ & $6 "$ & 6" & 100 \\
\hline 7 & $66^{\prime \prime}$ & - $78^{\prime \prime}$ & $12^{\prime \prime}$ & $8^{\prime \prime}$ & 67 \\
\hline 8 & $78^{\prime \prime}$ & - $84^{\prime \prime}$ & $6 "$ & $6^{\prime \prime}$ & 100 \\
\hline 9 & $84 "$ & $-96^{\prime \prime}$ & $12^{\prime \prime}$ & $12 "$ & 100 \\
\hline 10 & $96 "$ & - 108" & $12^{\prime \prime}$ & $12^{\prime \prime}$ & 100 \\
\hline 11 & $108^{\prime \prime}$ & $-116^{\prime \prime}$ & 8" & $7^{\prime \prime}$ & 88 \\
\hline 12 & $116^{\prime \prime}$ & $-145^{\prime \prime}$ & 2911 & $19 !$ & 6 \\
\hline 13 & $145^{i i}$ & - $159^{\prime \prime}$ & $14^{\prime \prime}$ & $14^{\prime \prime}$ & 100 \\
\hline 14 & $13.25^{\prime}$ & $-15.70^{\prime}$ & $2.45^{\prime}$ & $0^{\prime}$ & 0 \\
\hline 15 & $15.70^{\prime}$ & $-18.00^{\prime}$ & $2.30^{\prime}$ & $2.6^{\prime}$ & 113 \\
\hline 16 & $18.00^{\prime}$ & $=22.55^{1}$ & $4.55^{\prime}$ & $2.25^{\prime}$ & 49 \\
\hline 17 & $22.55^{\prime}$ & $-23.85^{\prime}$ & $1.30^{\prime}$ & $0.9^{\prime}$ & 69 \\
\hline 18 & $23.85^{\prime}$ & $-26.3 b^{\prime}$ & $2.50^{\circ}$ & $2.0^{\prime}$ & 80 \\
\hline 19 & $26.35^{\prime}$ & $-28.35^{\prime}$ & $2.00^{\prime}$ & $0^{\prime}$ & 0 \\
\hline 20 & $28.35^{\prime}$ & $-29.35^{\prime}$ & $1.00^{\prime}$ & $2.15^{\prime}$ & 215 \\
\hline 21 & $75.00^{i}$ & $-85.3^{\prime}$ & $10.3^{\prime}$ & $10.3^{i}$ & 100 \\
\hline 22 & $85.3^{\prime}$ & $-90.2^{\prime}$ & $4.9^{\prime}$ & $4.8^{\prime}$ & 98 \\
\hline 23 & $90.2^{\prime}$ & -95.21 & $5.0^{\prime}$ & $4.65^{\prime}$ & 93 \\
\hline 24 & $95.2^{\prime}$ & $-102.7^{\prime}$ & $7.5^{\prime}$ & $7.65^{\prime}$ & 102 \\
\hline 25 & $102.7^{\prime}$ & $-108.2^{\prime}$ & $5.5^{\prime}$ & $5.5^{\prime}$ & 100 \\
\hline 26 & $108.2^{\prime}$ & $=113.2^{\prime}$ & $5.0^{\prime}$ & $4.9^{\prime}$ & 98 \\
\hline 27 & $113.2^{\prime}$ & $-118.2^{\prime}$ & $5.0^{\prime}$ & $5.15^{\prime}$ & 103 \\
\hline 28 & $118.2^{\prime}$ & $-123.2^{\prime}$ & $5.0^{\prime}$ & $5.1^{1}$ & 102 \\
\hline 29 & $123.2^{\prime}$ & $-128.2^{\prime}$ & $5.0^{\prime}$ & $5.0^{\prime}$ & 100 \\
\hline 30 & $128.2^{\prime}$ & $-133.2^{\prime}$ & $5.0^{\prime}$ & $4.9^{\prime}$ & 98 \\
\hline 31 & $133.2^{\prime}$ & $-138.2^{\prime}$ & $5.0^{\prime}$ & $5.1^{\prime}$ & 102 \\
\hline 32 & $138.2^{\prime}$ & $-143.2^{\prime}$ & $5.0^{\prime}$ & $5.0^{\prime}$ & 100 \\
\hline 33 & $143.2^{\prime}$ & -149.2 & $6.0^{1}$ & $6.1^{\prime}$ & 102 \\
\hline 34 & $149.2^{\prime}$ & $-153.2^{\prime}$ & $4.0^{\prime}$ & $3.7^{\prime}$ & 93 \\
\hline 35 & $153.2^{\prime}$ & -158.2 & $5.0^{\prime}$ & $4.2^{1}$ & 84 \\
\hline 36 & 158.2 & $-162.2^{\prime}$ & $4.0^{\prime}$ & $2.7^{\prime}$ & 68 \\
\hline 37 & 162.21 & $-164.2 !$ & 2.01 & $3.5^{1}$ & 175 \\
\hline 38 & $164.2^{\prime}$ & $-160.2^{\prime}$ & $4.0^{1}$ & $3.9^{\prime}$ & 98 \\
\hline 39 & $168.2^{\prime}$ & $-173.2^{1}$ & $5.0^{\prime}$ & $4.9^{1}$ & 98 \\
\hline 40 & $173.2^{\prime}$ & $-178.2^{\prime}$ & $5.0^{1}$ & $3.9^{\prime}$ & 78 \\
\hline 41 & $178.2^{\prime}$ & $-183.2^{\prime}$ & $5.0^{1}$ & $6.3^{\prime}$ & 126 \\
\hline 42 & $183.2^{\prime}$ & $-188.2^{\prime}$ & $5.0^{\prime}$ & 5.11 & 102 \\
\hline 43 & $188.2^{\prime}$ & $-193.2^{\prime}$ & $5.0^{\prime}$ & $5.0^{\prime}$ & 100 \\
\hline 44 & $193.2^{\prime}$ & $-198.2^{\prime}$ & $5.0^{\prime}$ & $5.2^{\prime}$ & 104 \\
\hline 45 & $198.2^{\prime}$ & -203.2 & $5.0^{\prime}$ & $5.0^{\prime}$ & 100 \\
\hline
\end{tabular}


Table 1 (cont)

\begin{tabular}{|c|c|c|c|c|c|}
\hline Core No. & \multicolumn{2}{|c|}{ Interval } & Cored & Recovered & \% Recovery \\
\hline 46 & $203.2^{\prime}$ & $-206.6^{\prime}$ & $3.4^{\prime}$ & $3.2^{\prime}$ & 94 \\
\hline 47 & $206.6^{\prime}$ & $-213.2 !$ & $6.6^{\prime}$ & $6.6^{\prime}$ & 100 \\
\hline 48 & $213.2^{\prime}$ & $-218.2^{\prime}$ & $5.0^{\prime}$ & $4.98^{\prime}$ & 100 \\
\hline 49 & $218.2^{\prime}$ & $-226.3^{\prime}$ & $8.7^{1}$ & $8.3^{1}$ & 103 \\
\hline 50 & $226.3^{\prime}$ & $-231.4^{\prime}$ & $5.7^{1}$ & $5.0^{\prime}$ & 98 \\
\hline 51 & $231.4^{\circ}$ & $-238.2^{\prime}$ & 6.8 & $6.8^{\prime}$ & 100 \\
\hline 52 & $238.2^{\prime}$ & -246.7 & $8.5^{\prime}$ & $8.5^{\prime}$ & 100 \\
\hline 53 & $246.7^{\prime}$ & $-253.2^{\prime}$ & $6.5^{\prime}$ & $6.5^{\prime}$ & 100 \\
\hline 54 & $253.2^{\prime}$ & $-261.2^{\prime}$ & $8.0^{\prime}$ & $8.0^{\prime}$ & 100 \\
\hline 55 & $261.2^{\prime}$ & $-269.2^{\prime}$ & $8.0^{\prime}$ & $7.9^{\prime}$ & 99 \\
\hline 56 & $269.2^{\prime}$ & $-277.2^{1}$ & $8.0^{\prime}$ & $8.1^{\prime}$ & 101 \\
\hline 57 & $277.2^{\prime}$ & $-285.2^{\prime}$ & $8.0^{\prime}$ & $8.0^{\prime}$ & 100 \\
\hline 58 & $285.2^{\prime}$ & $-293.2^{\prime}$ & $8.0^{4}$ & $8.0^{\prime}$ & 100 \\
\hline 59 & $293.2^{\prime}$ & $-298.2^{\prime}$ & $5.0^{\prime}$ & $5.0^{\prime}$ & 100 \\
\hline 60 & $298.2^{\prime}$ & $-303.2^{\prime}$ & $5.0^{\prime}$ & $4.5^{\prime}$ & 90 \\
\hline 61 & $303.2^{\prime}$ & $-312.2^{\prime}$ & $9.0^{\prime}$ & $9.5^{\prime}$ & 104 \\
\hline 62 & $312.2^{\prime}$ & $-321.2^{\prime}$ & $9.0^{\prime}$ & $9.0^{\prime}$ & 100 \\
\hline 63 & $321.2^{\prime}$ & $-333.2^{\prime}$ & $12.0^{\prime}$ & $9.9^{\prime}$ & 83 \\
\hline 64 & $333.2^{\prime}$ & $-341.7^{1}$ & $8.5^{1}$ & $8.5^{\prime}$ & 100 \\
\hline 65 & $341.7^{\prime}$ & $-348.2^{\prime}$ & $6.5^{\prime}$ & $6.5^{\prime}$ & 100 \\
\hline 66 & $348.2^{\prime}$ & $-358.2^{\prime}$ & $10.0^{\prime}$ & $10.0^{\prime}$ & 100 \\
\hline 67 & $358.2^{\prime}$ & $-364.2^{\prime}$ & $6.0^{1}$ & $6.0^{\prime}$ & 100 \\
\hline 68 & $364.2^{\prime}$ & $-372.6^{\prime}$ & $8.4^{\prime}$ & $7.6^{1}$ & 91 \\
\hline 69 & $372.6^{\prime}$ & $-381.2^{\prime}$ & $8.6^{\prime}$ & $6.2^{\prime}$ & 72 \\
\hline 70 & $381.2^{\prime}$ & $-384.4^{\prime}$ & $3.2^{\prime}$ & $4.2^{\prime}$ & 131 \\
\hline 71 & $384.4^{\prime}$ & -391.2 & $6.8^{\prime}$ & $6.5^{\prime}$ & 96 \\
\hline 72 & $391.2^{\prime}$ & $-396.2^{\prime}$ & $5.0^{\prime}$ & $3.9^{\prime}$ & 78 \\
\hline 73 & 396.2 ' & $-400.9^{\prime}$ & $4.7^{1}$ & $4.5^{\prime}$ & 96 \\
\hline 74 & 400.9 & $-407.9^{\prime}$ & $7.0^{\prime}$ & $7.0^{\prime}$ & 100 \\
\hline 75 & $407.9^{\prime}$ & $-417.2^{\prime}$ & $9.3^{\prime}$ & $9.2^{\prime}$ & 99 \\
\hline 76 & $417.2^{\prime}$ & $-426.2^{\prime}$ & $9.0^{\prime}$ & $8.6^{\prime}$ & 96 \\
\hline 77 & $426.2^{\prime}$ & $-435.2^{\prime}$ & $9.0^{\prime}$ & 9.11 & 101 \\
\hline 78 & $435.2^{\prime}$ & $-443.2^{\prime}$ & $8.0^{\prime}$ & $3.0^{\prime}$ & 38 \\
\hline 79 & $443.2^{\prime}$ & $-446.2^{\prime}$ & $3.0^{\circ}$ & $3.0^{\prime}$ & 100 \\
\hline 80 & $446.2^{\prime}$ & $-453.2^{\prime}$ & $7.0^{\prime}$ & $7.0^{\prime}$ & 100 \\
\hline 81 & $453.2^{\prime}$ & $-460.2^{\prime}$ & $7.0^{\circ}$ & $8.0^{\prime}$ & 114 \\
\hline 82 & $460.2^{\prime}$ & $-468.2^{\prime}$ & $8.0^{\circ}$ & $8.0^{\prime}$ & 100 \\
\hline 83 & $468.2^{\prime}$ & $-477.2^{\prime}$ & $9.0^{\prime}$ & $9.5^{\prime}$ & 106 \\
\hline 84 & $477.2^{\prime}$ & $-479.9^{\prime}$ & $2.7^{\prime}$ & $2.0^{\prime}$ & 74 \\
\hline 85 & '479.9 & $-489.2^{\prime}$ & $9.3^{\prime}$ & $1.0^{\prime}$ & 11 \\
\hline 86 & $489.2^{\prime}$ & $-491.2^{\prime}$ & $2.0^{\circ}$ & $2.6^{\prime}$ & 130 \\
\hline 87 & $491.2^{\prime}$ & $-493.2^{\prime}$ & $2.0^{\prime}$ & $2.0^{\prime}$ & 100 \\
\hline 88 & $493.2^{\prime}$ & $-498.2^{\prime}$ & $5.0^{\circ}$ & $5.0^{\prime}$ & 100 \\
\hline 89 & $498.2^{\prime}$ & -505.7 & $7.5^{\prime}$ & $6.9^{\prime}$ & 92 \\
\hline 90 & $505.7^{\prime}$ & $-513.2^{\prime}$ & $7.5^{\prime}$ & $7.3^{\prime}$ & 97 \\
\hline 91 & $513.2^{\prime}$ & $-523.7^{\prime}$ & $10.5^{\prime}$ & $8.6^{\prime}$ & 82 \\
\hline 92 & $523.7^{\prime}$ & $-533.2^{\prime}$ & $9.5^{\prime}$ & $8.0^{\prime}$ & 84 \\
\hline 93 & $533.2^{\prime}$ & $-543.2^{\prime}$ & $10.0^{\prime}$ & $8.5^{\prime}$ & 85 \\
\hline
\end{tabular}


Table. 1 (cont)

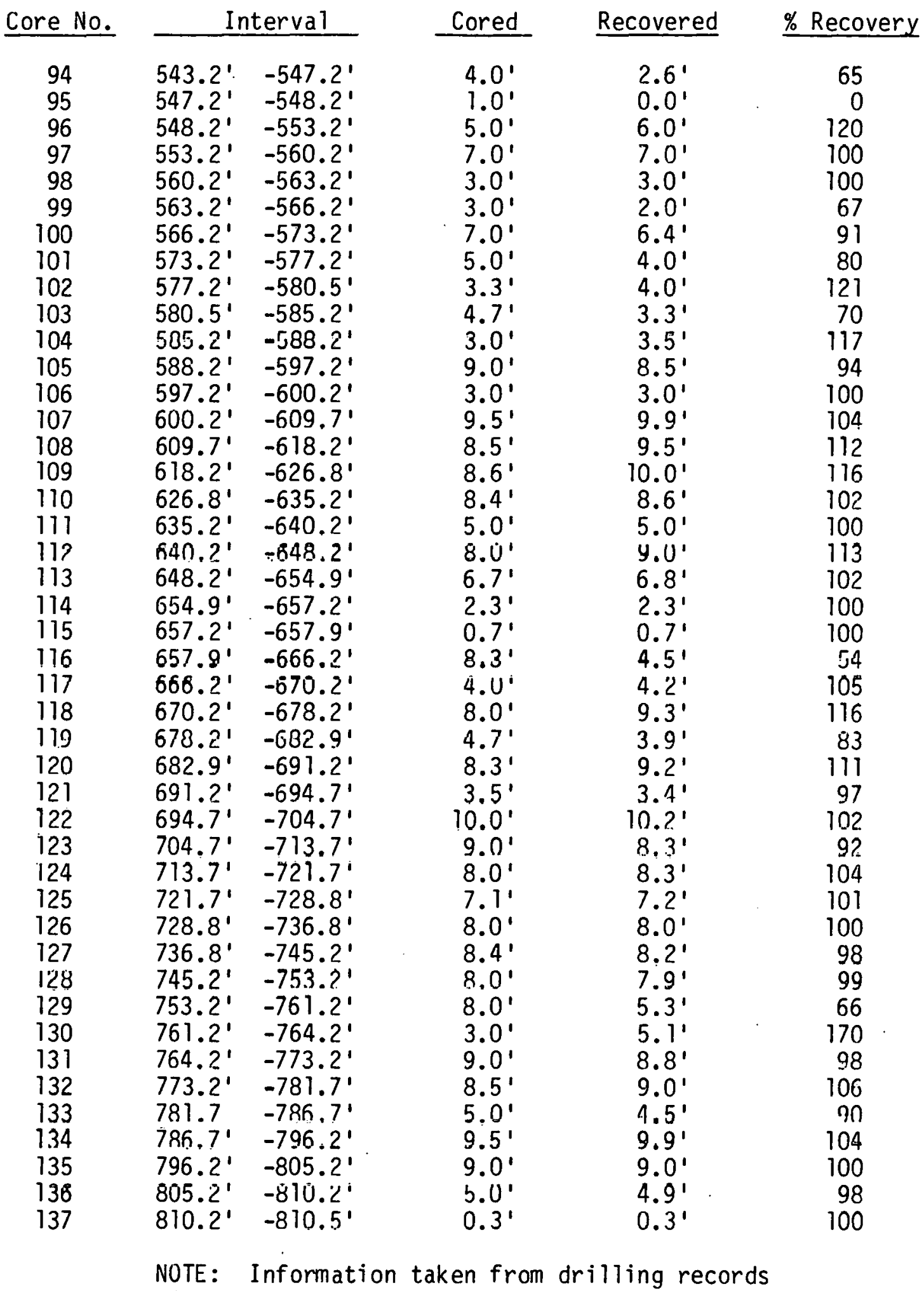


Table 2

Stratigraphic sumary of borehole WIPP 15

Rock Unit

Depth Interval

Feet

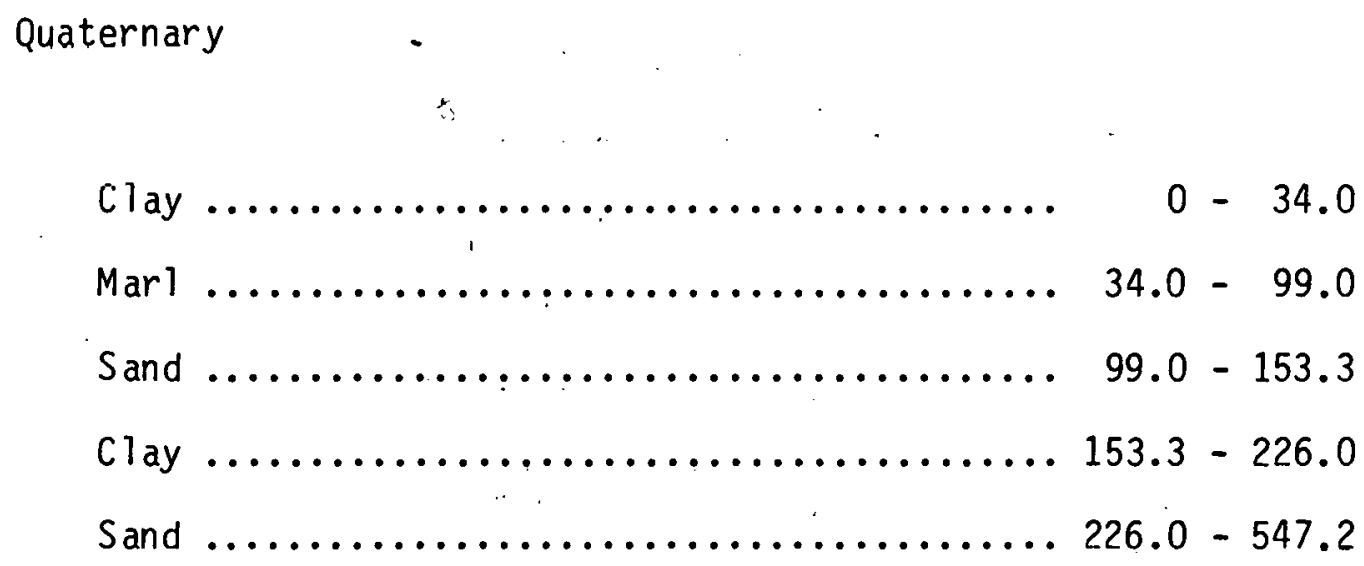

Triassic

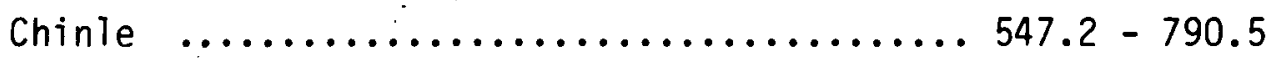

Santa Rosa (?) ....................... $790.5-812.0$ 
Table 3

Lithologic $\log$ for borehole WIPP -15

Color designations are from rock-color chart (Goddard, and others, 1963); (no core designates intervals where core was lost during drilling operations)

Lithologic Description

Depth Interval feet

Clay, light olive gray (5Y 6/1) to yellowish gray $5 Y$ $8 / 1$ ), calcareous, sandy, and/or silty, stringers of organic debris; sand is well-rounded, well-sorted quartz and

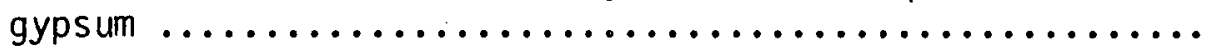

$0-11.0$

No core

$11.0-12.0$

Clay, very light gray (N8) to light gray (N7), unconsolidated, with dark gray (N3) mottling of organic debris; "limonitic" cemilulèd zones and stains

$12.0=13.3$

No core

$13.3-15.4$

Clay, same as unit at $12.0-13.3$

$15.4-20.3$

No core

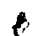

$20.3-22.5$

Clay, sdlle ds unit at $12.0-13.3$ feet, silty.

$22.5-25.5$

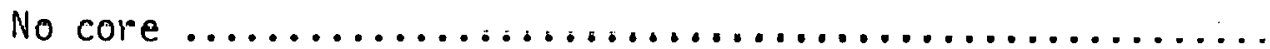

$25.5-26.5$

Clay, same as unit at $22.5-25.5$

$26.5-34.0$

Sand, pale yellowish brown $(10$ YR $6 / 2)$, well rounded, well sorted gypsum and quartz, very calcareous, silty and clayey

$34.0-39.0$

Marl, very light gray (N8) to light gray (N7), or pale yellowish brown $(10 \overline{Y R} 6 / 2)$ sill-cilay, unconsolidated ...

$39.0 \cdot 41.5$

Marl, sandy at base, fining upward to very light gray (N8) clay. Light bluish gray $(5 B-7 / 1)$ to light greenish gray (5G 8/1) mottling, organic rich layers, dark gray (N3) ..

Sand, yellowish gray $(5 \underline{y} 7 / 2)$, silty, very calcareous ..... Sard, same as urit at 51.0 - 59.5 feet, but non."calcarcous .

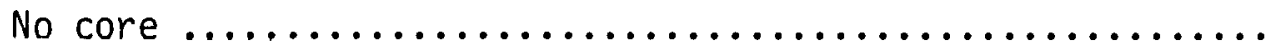

Marl, same as unit at $39.0-41.5$ feet $\ldots \ldots \ldots \ldots \ldots \ldots$

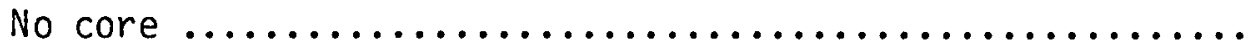

$41.5-51.0$

$51.0=59.5$

$59.5-61.0$

$61.0-63.0$

$63.0-65.2$

$65.2-73.2$ 
Table 3: Lithologic log for borehole WIPP-15, cont.

Sand, pale olive (10 $\underline{y} / 2)$, calcareous, pebbly, clayey ....

$73.2-78.0$

Marl, yellowish gray (5Y 7/2), calcareous silty clay or clayey silt limonitic(?) veins, dark yellowish orange $(10 Y R$ 6/6), gypsum crystals and stringers $. . . \ldots \ldots \ldots . . .$.

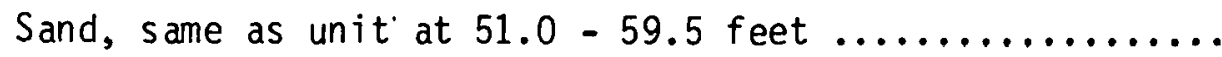

Marl, same as unit at 39.0 - 41.5 feet, yellowish gray

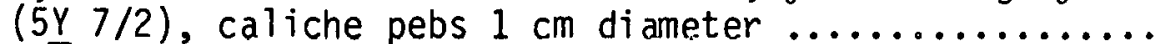

$94.5-99.0$

Sand, moderate greenish yellow (10Y $7 / 4$ ) to pale olive (10Y 6/2) clayey and calcareous quartzose, subrounded, moderate sorting. Caliche pebs at 112 to 114 feet. Calcareous fracture filling and light brown (5YR 6/4) calcareous sand at 118 feet grades up to pale olive (10Y 6/2) sand. Moderate brown (5YR 3/4) clay blebs at 120 feet. Gypsum veins at 127 feet. Calcareous veins

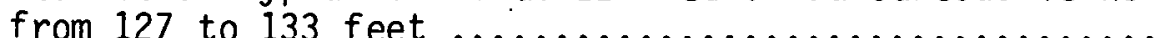

Sand, dusky yellow (5Y 6/4), very calcareous, calcareous

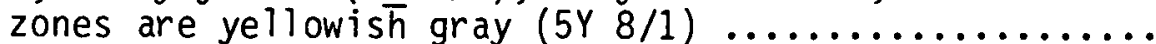

$133.0-153.3$

Sand, same as unit at 99.0 - 133.0 feet with lenses of light brown (5YR 6/4) sand and yellowish gray (5Y 8/1) calcareous zones

No core

Clay, moderate brown (5YR 3/4), with light bluish gray $(5 \underline{B} 7 / 1)$ sand in veins.

Sand, moderate brown (5YR 3/4), clayey, silty, pebbly from 169 - 171 feet; caliche peb. $.5 \mathrm{~cm}$ in diameter, slightly calcareous, lenses of light bluish gray (5B 7/1) sand. Gypsum vein $.5 \mathrm{~cm}$ thick at 182 feet $\ldots \ldots \ldots \ldots \ldots \ldots . . . . .$.

$169.0-184.0$

Clay, moderate brown (5YR 3/4) to grayish red (10R 4/2); silty and/or sandy in thin lenses. Laminations at 207 feet $11 \mathrm{~cm}$ zone with 24 laminations; $12 \mathrm{~cm}$ zone with 22 laminations. Dark yellowish orange (10YR 6/6) sand in irregular blebs at 208-210 feet. Calcareous clay from

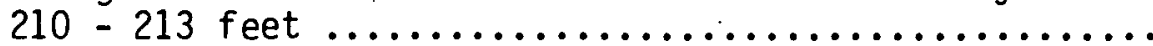


Table 3: lithologic log for borehole WIPP-15, cont.

Lithologic Description

Depth Interval feet

Clay, light olive gray (5YR 6/1), calcareous, organic debris, mottled with moderate reddish brown (10R 4/6) clay from 220 - 222 feet. Moderate reddish brown sand and clay mottled with light olive gray (5 $\underline{Y} 6 / 1)$ clay

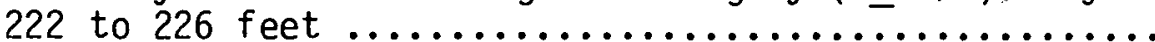

$213.0-226.0$

Sand, moderate reddish brown (10R 4/6), clayey, calcareous, unconsolidated, moderate brown clay (5YR $3 / 4$ ) at 233-234 feet. Caliche pebs, $3 \mathrm{~cm}$ in diameter at 238-239 feet. Light bluish gray $(5 \underline{B} 7 / 1)$ sand, very calcareous $w /$ calcareous blebs, from 239 to 243 feet. Calcite veins

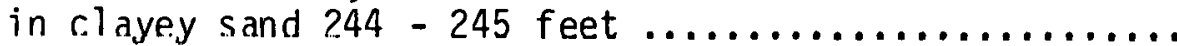

Clay, moderate reddish brown (10R 4/6), calcareous, mottled with light olive gray $(5 \underline{Y} 6 / 1)$ clay, fractures with

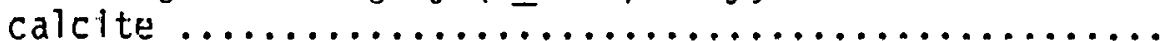

Sand, same as unit at $226.0-245.0 \mathrm{ft}$, moderate brown (5YR 3/4) clay lenses at 263, 273, 276 feet. Caliche

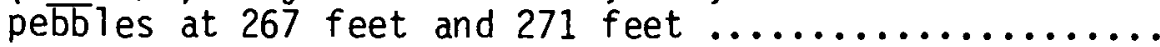

$251.0-284.0$

Clay, sandy and calcareous; alternated with zones of clayey calcarcous sand, light olive gray (5Y 6/1) clay blebs..

$284.0-292.0$

Sand, same as unit at 226.0 - 245.0 feet. Pebbles at 294.0 295.0 feet, caliche pebble zone from $296-297$ feet,

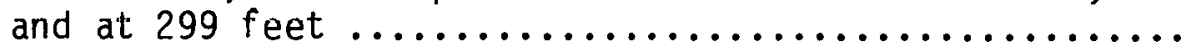

$292.0-299.0$

Clay, same as unit at $184.0-213.0$ feet, light olive gray (5Y 6/1) calcareous clay in fractures. Pebble conglomerate at $301 \mathrm{feet}, 302.5$ feet ..................

$299.0-304.5$

Sand, same as unit at 226.0 - 245.0 feet. Frequent calcareous-cemented zones. Caliche pebbles at $319 \mathrm{ft}$.. $\quad 304.5-321.2$

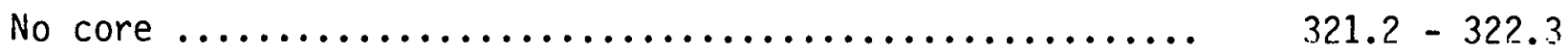

Sand, same as unit 226.0 - 245.0 feet. Caliche pebble conglomerates at $322.3,341-342,346,349-350$, 362 - 36606,373 feet pebbles or sandslune, 1 imeslunie, siltstone, caliche up to $4 \mathrm{~cm}$ in diameter. Moderate brown (5YR 3/4) clay and sandy clay lenses at $330-332$, 346 and $\overline{367}-371$ feet. Sand in fractures in clay 
Table 3: lithologic log for borehole WIPP-15, cont. feet

No core

$380.0-381.0$

Sand, same as unit at 226.0 - 245.0 feet. Clayey very angular 3-5 mm diameter caliche, limestone, and sandstone pebbles at 384 feet $\ldots \ldots \ldots \ldots \ldots \ldots \ldots \ldots \ldots$.

$381.0-391.2$

No core

$391.2-392.4$

Sand, same as unit at $226.0-245.0$ feet. Very clayey. Pebbles at $392.4-394,396,398$, and scattered throughout unit. Diameters from $1 \mathrm{~mm}-1 \mathrm{~cm}$. Clay blebs from 406 - 411 feet, clay content decreases from 411 - 217 feet, grading into light brown (5YR 5/6) sand

$392.4-411.0$

Sand, light brown (5YR 5/16), unconsolidated quartzose, medium to fine grained, clayey and/or calcareous zones, calcareous blebs. Calcareous zones are consolidated, cemented zones from 418 - 426 feet

$411.0-435.2$

No core

$435.2-439.5$

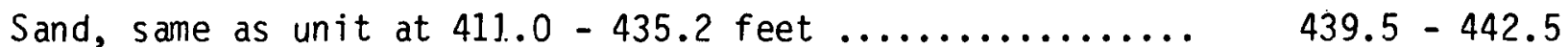

No core

$442.5-444.2$

Sand, same as unit at $411.0-435.2$ feet

$444.2-460.2$

No core...

$460.2-461.2$

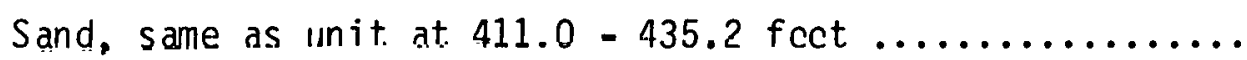

No core

$461.2-480.0$

$.480 .0-489.2$

Sand, same as unit at $411.0-435.2$ feet ............. $489.2-498.3$

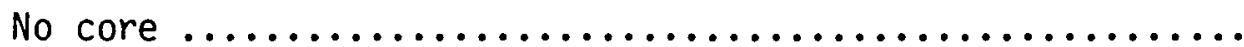

$498.3-503.2$

Sand, same as unit at $411.0-435.2$ feet $\ldots \ldots \ldots \ldots \ldots \ldots .6503 .2-523.7$

No core

$523.7-525.5$ 
Table 3: lithologic log for borehole WIPP-15, cont.

Sand, same as unit at $411.0-435.2$ feet, light olive gray (5Y 3/4) sand and clay blebs and moderate brown

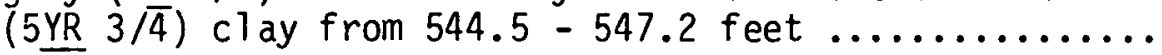

$525.5-547.2$

Claystone, dark reddish brown (10R 3/4) to grayish red ( $5 R$ 4/2), hard, silty, mottled with light bluish gray $(5 \bar{B} 7 / 1)$ clay, and limonitic stained clay. Calcareous blébs from 550 - 554 feet. Gypsum vein at 554 feet. Limestone and clay pebbles at 557 feet

$547.2-565.0$

No core $565.0-559.0$

Claystone, same as unit at 547.2 - 565.0 feet. Fractures and deformation, mottling from 569.0 - 573.0 feet. Calcareous zones and dessication features and fracture zones 591 - 594 feet. Calcite-filled fractures at 607 feet, grades down to medium gray (N5) claystones .......

$569.0-640.5$

Claystone, medium gray (N5) to dark reddish brown (10R 3/4), hard, silty, calcareous blebs, blebs of light bluish gray $(5 \underline{B} 7 / 1)$ clay .............................. $640.5-658.0$

No core $658.0-661.0$

Claystone, same as unit at 547.2 - 565.0 feet, intraformational pebble conglomerate with clay interbeds

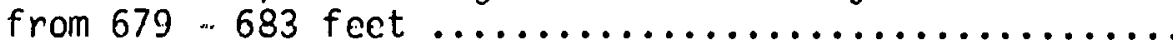

$661.0-706.0$

Siltstone, light greenish gray $(5 G 8 / 1)$ banded with grayish red (10R 4/2), sandy, clavey, Taminated, fractured and brecciated. Dips $10^{6}$............................

$706.0-716.5$

Claystone, grayish red (10R 4/2) and light greenish gray (5G 8/1), silty, laminated, calcareous blebs ...........

S1ltstone, graytsh red (10R 4/2) to pale red (10R 6/2), clayey laminated, alternating $\mathrm{w} /$ bands of silty sandstone and claystone, calcareous zones and light greenish gray (5G 8/1) zones. Micaceous sand at 728 feet. Clay balls and lenses at 734 feet. Dip $10^{\circ}$ 
Table 3: lithologic log for borehole WIPP-15, cont.

Conglomerate, grayish purple (5P 4/2), rounded limestone claystone, siltstone pebbles, graded up, .5 - .1 cm in diameter, calcareous cement; interbeds of light brownish gray $(5 Y R$ $6 / 1)$ and light greenish gray $(5 \underline{G} 8 / 1)$

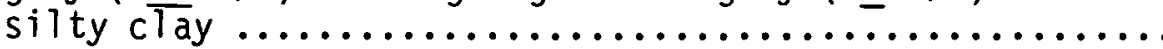

Sandstone, light brownish gray (5YR 6/1), cross bedded, calcareous cement, light bluish gray (5 silt at 757 feet, dips $20^{\circ}$

Claystone, moderate brown (5YR $3 / 4$ ) to grayish red $(10 \mathrm{R} 4 / 2)$, silty, calcareous in places, 1 aminated, $15-20^{\circ}$ dip. $1 \mathrm{~cm}$ thick zones of light bluish gray (5B 7/1) calcareous clay banded in moderate brown (5Y⿱乛龰R 3/4) clay, at 762 feet. Cross bedded, silty calcareous sand from 767.5 - 768.5 feet. Fault with

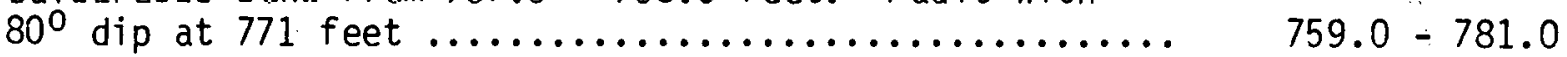

Siltstone, some claystone, moderate reddish brown (10R 4/6), clayey, sandy, calcareous; light bluish gray $(5 B, 7 / 1)$ reduced zones. Much faulting and fracturing. $781.0-790.5$

Sandstone, light brownish gray (5YR 6/1), fine to medium grained, moderately consolidated, cross bedded, some clay matrix. Dips $12-15^{\circ}$. Moderate brown (5YR 3/4) clay at 795.5 to 797 feet. Unconsolidated sand 797 798 feet, very calcareous zone at 803 feet ............. 


\subsection{HYDROLOGIC DATA}

by

Don D. Gonzalez

WIPP 15 was drilled in an effort to characterize a topographic depression referred to as "San Simon Sink" and to determine its relationship to deep dissolution and an understanding of the pluvial lake environment of San Simon Swale.

The stratigraphic section and final well completion for WIPP 15 is shown in Fig. 5 .

The hole was drilled to a total depth of 810 feet into the Santa Rosa Sandstone, a major aquifer in southeast Texas, particularly along the Pecos River. Overlying the Santa Rosa Sandstone are about 225 feet of Triassic Chinle rocks consisting of silt and mudstones, not noted for capabilities t.n retain and/or yield water of appreciable quantities. The upper 555 feet of well was cased in Quaternary sands and clays; the casing was slotted from 445-540'. Water levels during drilling and completion were reported as about 100 feet below 1 and surface.

Attempts to bail-test the hole produced insignificant results because of high yields and excessive in-flow of sands due to the lack of well development. A chemical analysis of water taken from WIPP 15 after 150 bails is shown on Table 4. 
Table 4

Quality of Groundwater

WIPP 15

Quaternary Sands/Clays

Bailed Sample: March 12, 1979, a 1400 hours

\begin{tabular}{|c|c|c|c|c|}
\hline $\begin{array}{c}\text { Alkalinity } \\
\left(\mathrm{CaCO}_{3}\right)\end{array}$ & $\begin{array}{l}\text { Hardness } \\
\left(\mathrm{CaCO}_{3}\right)\end{array}$ & $\begin{array}{l}\text { Dissolved } \\
\text { Calcium } \\
\text { (Ca) }\end{array}$ & $\begin{array}{l}\text { Dissolved } \\
\text { Magnesium } \\
\text { (Mg) }\end{array}$ & $\begin{array}{l}\text { Dissolved } \\
\text { Sodium } \\
\text { (Na) }\end{array}$ \\
\hline $\mathrm{mg} / \mathrm{l}$ & $\mathrm{mg} / \mathrm{l}$ & $\mathrm{mg} / \mathrm{l}$ & $\mathrm{mg} / \mathrm{l}$ & $\mathrm{mg} / \mathrm{l}$ \\
\hline 810 & 420 & 35 & 81 & 300 \\
\hline
\end{tabular}

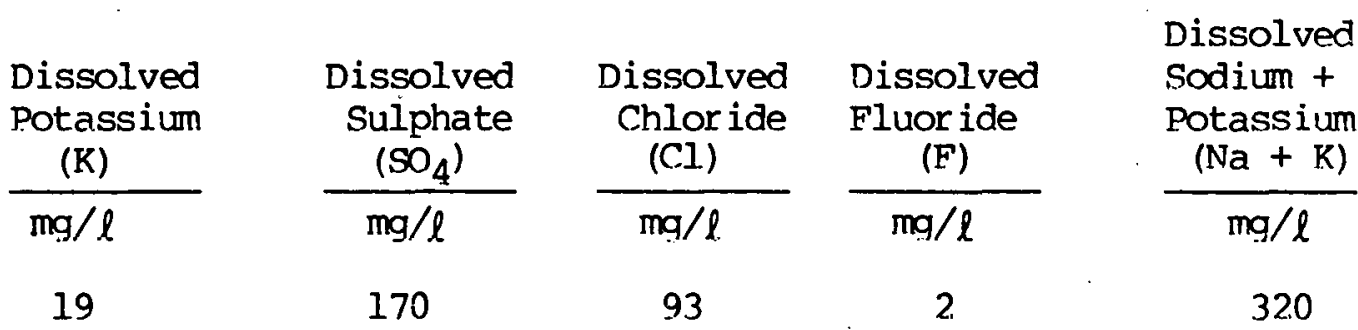

Dissolved

Sodium

Silica

$\mathrm{mg} / \mathrm{l}$

Absorption

Specific

Ratio

$\begin{array}{cc}\frac{\text { Conductance }}{\text { micro-mhos }} & \stackrel{\mathrm{PH}}{\text { not }} \\ 1900 & \text { determined }\end{array}$

Temperature

Deg C

35

5.4

Dissolved

Dissolved

Dissolved

gross alpha

Dissolved

Barium.

Boron

Solids

$\frac{(\mathrm{Ba})}{\mu \mathrm{q} / \ell}$

$\frac{(\mathrm{B}}{\mu \mathrm{g} / \ell}$

(natural Ur)

$\mathrm{mg} / \mathrm{l}$

$\mu \mathrm{g} / \mathrm{l}$

gross-beta

200

1000

1220

$<23$

27

18

Dissolved Dissolved radium-226 Uranium

$\frac{\text { (radon method) }}{\mathrm{pC} / \ell} \frac{(\mathrm{U})}{\mu \mathrm{q} / \ell}$

$0.2 .1 \quad 0$ 
On October 9, 1979, WIPP 15 was tested using conventional aquifer pump-test methods for estimates of transmissivity in an unconfined aquifer. The saturated thickness was 430 feet of Quaternary sands and clays; there were no observation holes. The aquifer was pumped for 72 hours at a rate of 5.72 gallons per minute resulting in a maximum drawdown of 7.62 feet (Fig. 6). The drawdown portion of the test curve. (Fig. 6) shows the effects of borehole storage and development (first 2-3 minutes) and the final rate of drawdown associated with the pump rate. The transmissibility calculated on the basis of late drawdown data was 323 feet squared per day. The recovery portion of the data, Fig. 7, typifies a normal recovery, the late portion of the curve indicating that time period where the aquifer is responding to the initial pumping stress as close to a natural condition as possible. The calculation of transmissibility resulting from late dat.a, 616 feet squared per day, is the best estimate for the transmissive capabilities of this unconfined aquifer near the vicinity of WIPP 15.

The relatively high value for transmissibility and small amounts of drawdown versus pumping rate show that pumping could be sustained for long periods of time and certainly could fulfill domestic demands several fold. The water quality, as indicated by the analysis of a bailed sample, shows that water drained from this aquifer could be used for livestock and agriculture, and is marginal for domestic use. Hardness and total dissolved solids are slightly higher in concentration than normal domestic standards. 
Feet

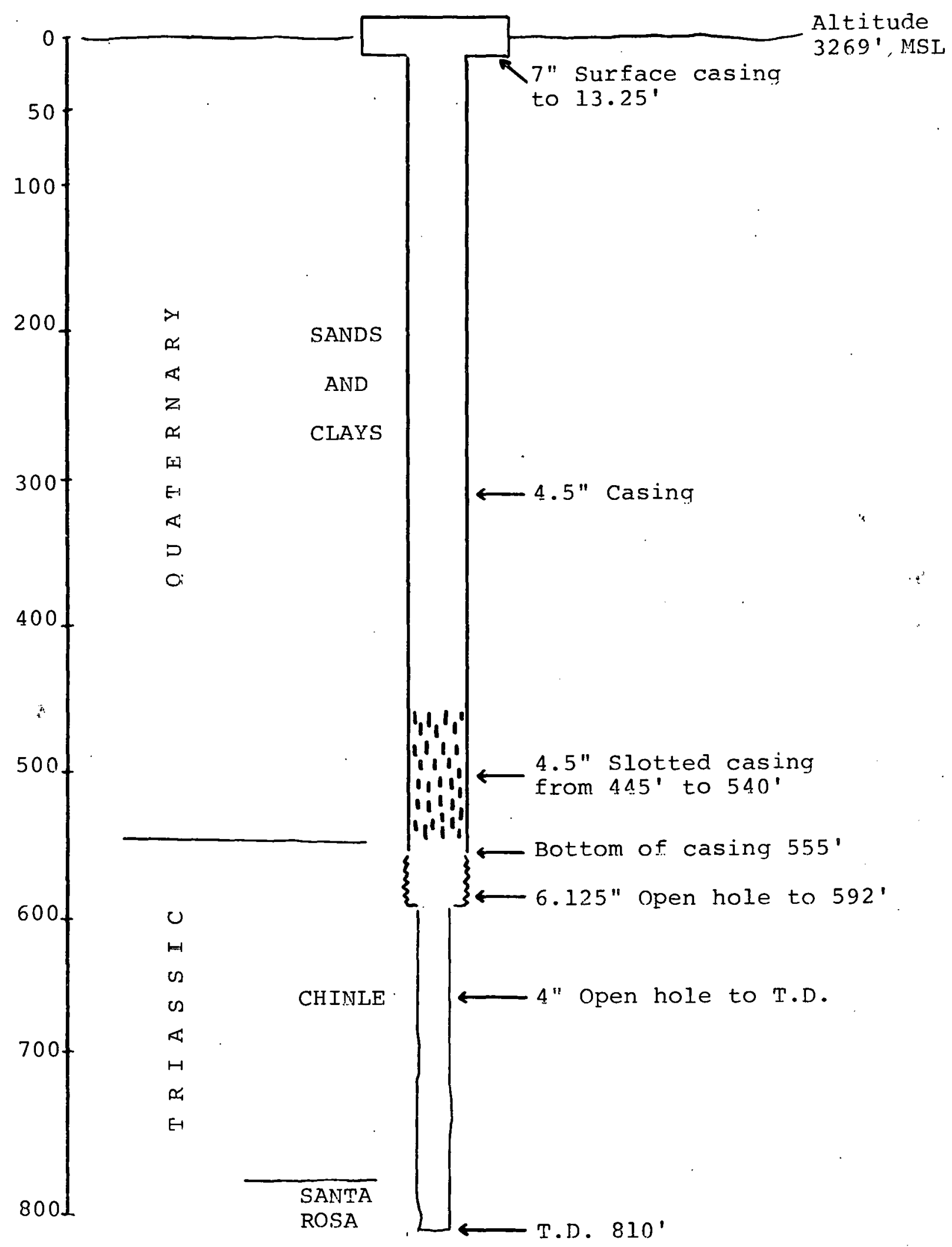

Figure 5. Stratigraphic and well completion diagram for WIPP 15, San Simon Sink 


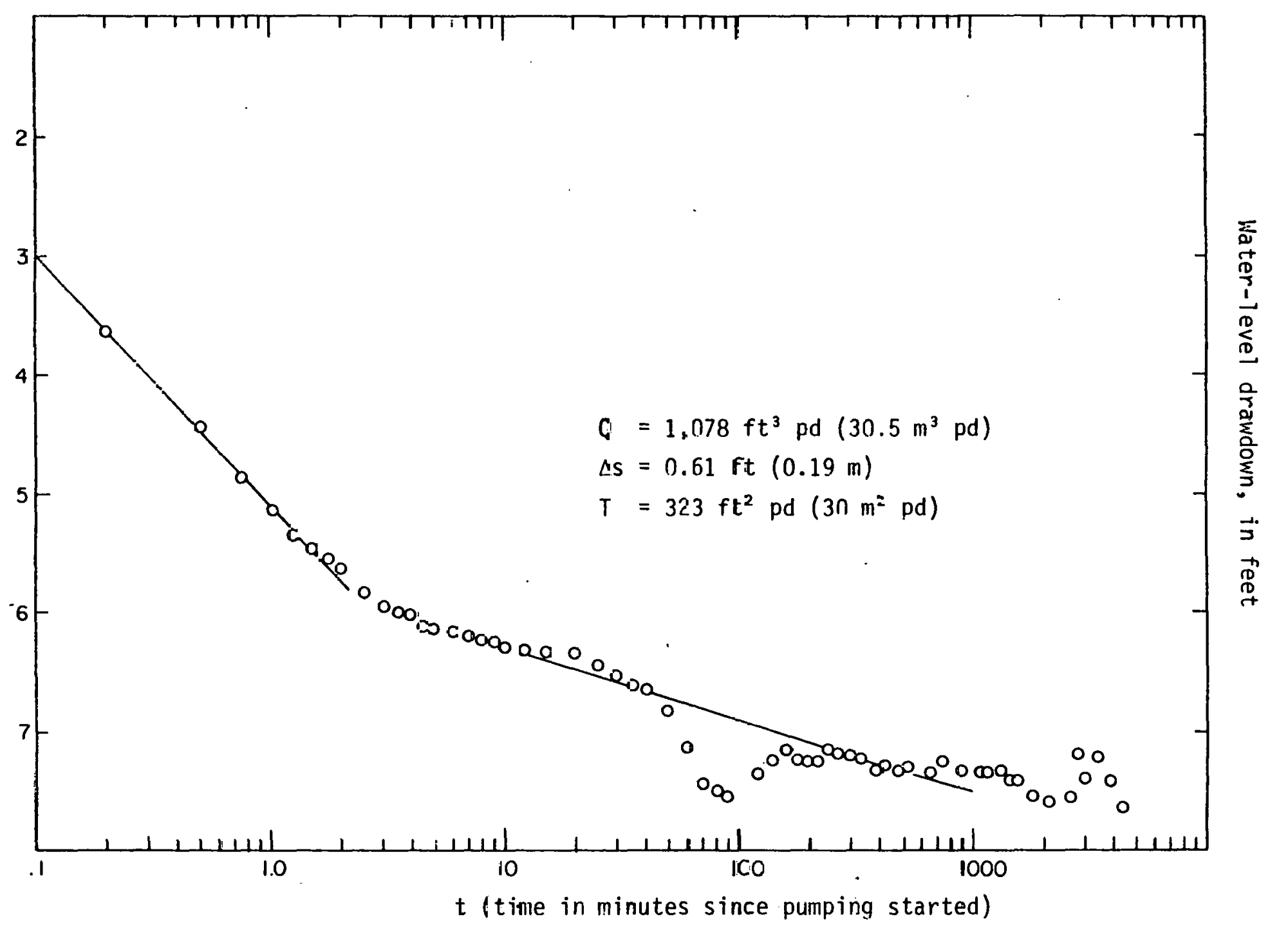

Figure 6 Plot of data collected during drawdo'sn of WIPP-15 well test, October 19-22, 1979 . 


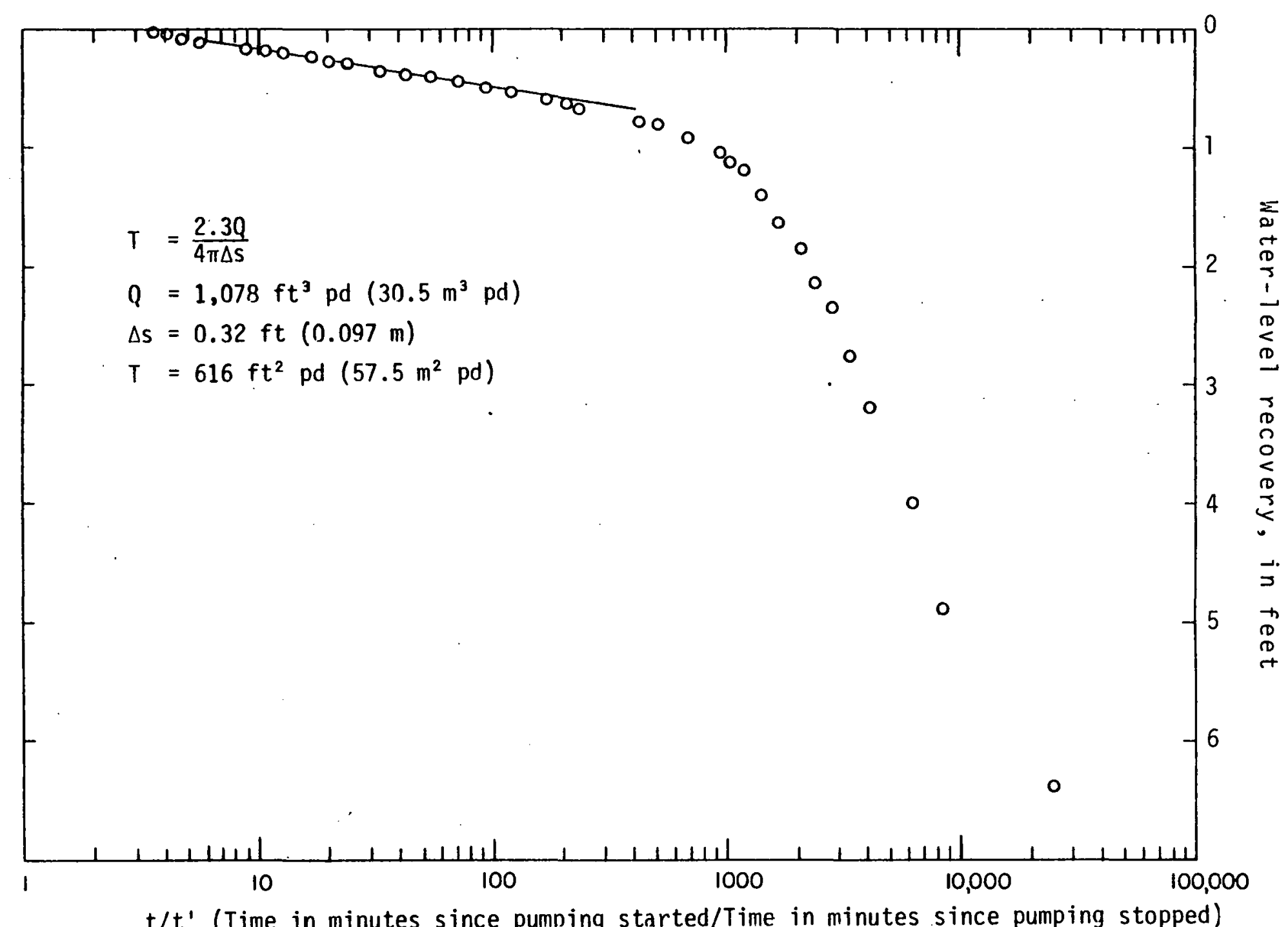

Figure 7. Plot of data collected during recovery of WIPP-15 well test, October 22-23, 1979. 


\subsection{REMARKS}

Following the drilling and testing of WIPP 15, the borehole was turned over to the control of the rancher holding the lease in order that he might use the well, if desired, for watering stock.' At the time of publication of this report, the well had not been produced. Production of water from WIPP 15 may have an effect on benchmarks in San Simon Sink; this will have to be accounted for in any future releveling of the lines.

WIPP 15 overlies the Capitan reef. It may be that the dissolution and collapse resulted from circulation of Capitan water. This has not been demonstrated for San Simon Sink, and the feature does not resemble either at the surface or in the subsurface the "breccia pipes" drilled in WIPP 16 and WIPP 31. The basic data reports for these latter boreholes have not yet been completed for comparison.

The basic conclusion from the fossil evidence (Rradbury, Appendix A) is that San Simon Sink was definitely a lake at. one time, probably during the Tahoka Pluvial of about 20,000 to 10,000 years b.p. Certain species indicate an arid or perhaps very arid period following the pluvial and before the present arid climate was established. nther recent work on late Cenozuic climates for the area are Bachman (1980) and Widdicombe (1980). 


\subsection{BIBLIOGRAPHY}

Bachman, G.0., 1980, Regional geology and Cenozoic history of Pecos region, southeastern New Mexico: U.S. Geological Survey, Open-File Report 80-1099.

Dunay, R. E. and Traverse, A., 1971, Preliminary report on Triassic spores and pollen of the Dockum Group, Texas Panhandle: Geoscience and Wan., v. III, p. 65-68.

Goddard, E. N., chm., and others, 1963, Rock-Color Chart: Washington, National Research Council (reprinted by Geological Society of America).

Powers, D. W., Lambert, S. J., Shaffer, S-E., Hill, L. R., and Weart, W. D., eds., 1978, Geological Characterization Report, Waste Isolation Pilot Plant (WIPP) Site, Southeastern New Mexico: SAND78-1596, vols. I and II.

Statler, R. D., 1978, WIPP 15 Field Engineering Summary: internal unpublished document, Sandia Laboratories, Albuquerque, NM.

Widdicombe, R., 1980, Quaternary surficial features in the Delaware Basin, Eddy and Lea Counties, New Mexico: unpublished M.S. thes is, University of New Mexico (report to Sandia National Laboratories). 
APPENDIX A-1

\author{
Report on Quaternary. Fossils from San Simon Sink, \\ Lea County, New Mexico 1
}

by

\author{
J. Platt Bradbury \\ Branch of Palentology \& Stratigraphy \\ U.S. Geological Survey
}

${ }^{1}$ The report on referred fossils is reprinted with the approval of J. P. Bradbury 


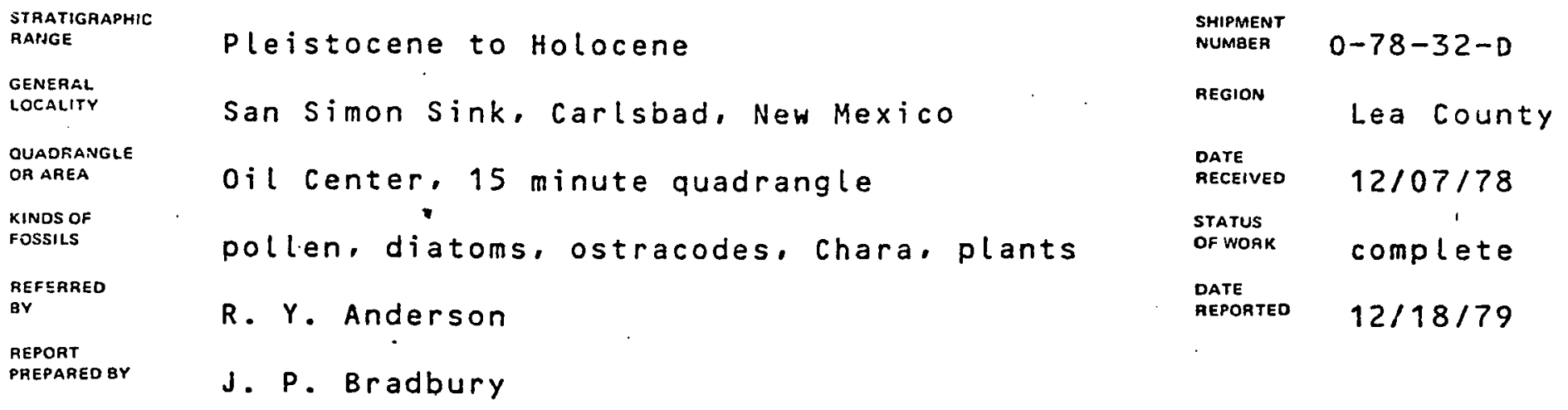

97 samples from a core in San Simon Sink. Lea County. New Mexico CFigure 1) were received and checked for microfossil content. The location of the core was approximately in the center of the sink, about $500 \mathrm{~m}$ east and $850 \mathrm{~m}$ north of the southwest corner of section 18, T23S, R35E, $0 \mathrm{il}$ Center 15 minute quadrangle. New Mexico. Seven additional samples, Woodwell Tank no. 1. Woodwell Tank no. 2, Pollen Trap 3-8/3-10 78 , Pollen Trap 3-13/3-17 78, Pollen Trap 3-20/3-24 78 and two samples of Drilling Mud were studied for pollen content in order to evaluate the pollen stratigraphy of the core samples. After initial inspection, 40 samples were prepared for pollen analysis. 17 of these proved barren of pollen. All the samples were checked for the presence of ostracodes. CHARA, silicified or carbonized plant remains, and snails. sixty-one samples were checked for the presence of diatoms. The analyticai results of this study are presented in Tables 1 and 2 , and in the following text.

\section{SUMMARY OF ANALYTICAL PROCEDURES AND RESULTS}

The modern pollen rain was determined by the analysis of two samples from Woodwell Tank, both of which contained sparse but reasonably wellpreserved pollen and from three pollen trap samples. The pollen trap samples consisted of $25 \mathrm{~cm}$ squares of aluminum foil. coated with vaseline and taped to a doghouse roof $3 \mathrm{~m}$ above the ground at the drill site. After several days of exposure, the aluminum foil was removed and the vaseline rinsed off with xylene. The residue was washed in methyl alcohol and prepared by HCl, HF and acetolysis pollen-analytical procedures. The pollen trap samples contained abundant, well-preserved pollen. The exposure times for the three pollen trap samples were 8 III 1978 to 10 III 1978, 13 III 1978 to 17 I I I 1978, and 20 III 1978 to 24 III 1978 , and represent a reasonably complete sampling of the early spring pollen rain in southern New Mexico. The Woodwell Tank samples presumably contain a longer modern pollen rain record although it is not known if the tank becomes dry seasonally, and how this might affect deposition of pollen. a

$$
\text { A- } 1-1
$$


STRATIGAAPHIC

RANGE

GENERAL

LOCALITY

GEGION

ouAORANGLE

OATE

OR AREA

AECEIVED

KINDS OP

STATUS

REFERED

REFERRED

OF WOAK

REPOAT

PAEPAAED oY

Drilling mud was analyzed for pollen from dates representing the middle and end of the coring operation. Drilling mud from 17 III 1978, taken during the middle of the coring operation contained pollon and was assigned pollen sample number 05971 . The mud sample from the end of the coring operation ( 30 II 1978) was barren of pollen.

Samples from the WIPP-15 core were processed for pollen using standard HCl. HF, acetolysis techniques. The pollen sum was approximately 200 grains excluding aquatics unless low pollen density precluded attaining this sum. In this case, all pollen grains on two $22 \mathrm{~mm}$ square coverslips. were counted.

All the 97 samples of the core were examined under a binocular stereo microscope for calcareous microfossils (CHARA, ostracodes and snails) and for plant remains. The presence of diatoms in selected samples. was cietermined by microscope examination of the powdered sediment immersed in indexwof-refraction oil (1.7).

All samples below $66.2 \mathrm{~m}$ depth were barren of fossils. Well-preservod pollen and carbonized plant fragments were present in samples $06049-A$ and $06049-B .66 .2$ and $65.6 \mathrm{~m}$ depth respectively. but above this depth the core was barren of all microfossils until $27.6 \mathrm{~m}$ depth where silicified $p l a n t$ remains became common. The lowest diatoms were found at a depth of $19.8 \mathrm{~m}$; the lowest ostracodes and CHARA oospores at a depth of 16.6 $m$. The distribution of calcareous and siliceous microfossils in the upper $27.6 \mathrm{~m}$ of the core are presented in Table 2 and graphically in Figure 2. (See Figure 4 of Chapter 3.)

\section{DISCUSSION}

THE MODERN POLLEN RAIN

The natural vegetation of the Permian Basin is dominated by herbaceous plants, principally Gramineae, Chenopodiaceae and Amaranthaceae. and Compositae. There are local concentrations of shin or pygmy caks (QUERCUS MOHRIANA) on sandy soils, particularly dune mantled areas, and of junipers (JUNIPERUS spo.) in rocky soils associated with escarpments and low cliffs such as are produced by the swales and sinks in this part of the basin. a

$$
A-1-2
$$




X
STRATIGRAPHIC
RANGE
GEHERAL
LOCALITY
QUADAANGLE
OR AREA
KINOS OF
FOSSILS
REFERRED
BY
REPORT
PREPARED BY

The modern pollen rain as represented by the pollen trap samples (Table 3 ) is clearly biased by the predominance of JUNIPERUS pollen that is produced in the early spring. The comparatively higher values of Chenopodiaceae-Amaranthaceae (Cheno-Am), Gramineae, and Compositae pollen in the Woodwell Tank samples suggest that they more accurately reflect the modern pollen rain on an annual basis because these plants $b$ loom and polinate in the mid-summer and $f a l l$ of the year. Modern pollen spectra from the Llano Estacado are characterizêd by wide. variability, but the two most abundant taxa are compositae and Chenopcdiaceae-Amaranthaceae coldfield and Schoenwetter, 1975. Hafsten. 1961), and the Woodwell Tank pollen spectra conform to this general. pattern. They are distinctive because they contain somewhat larger percentages of QUERCUS pollen than is usual for the Llano. Estacado. This may be a result of the numbers of pygmy oaks that grow on the sand dunes in the Los Medanos area west of San Simon Sink.

\section{POLLEN STRATIGRAPHY IN THE LLANO ESTACADO}

Between 1958 and 1963 several investigators have studied the pollen stratigraphy of late Quaternary playa lakes, spring-fed draws, and other basins in the LLano Estacado (Figure 2) in connection with archaeological excavations of paleoindian sites in west Texas and southeastern New Mexico. Thirteen sites, which together span the time beginning approximately 30,000 years ago and ending during the Altithermal (perhaps 5000 years ago) provide the baselines to interpret the fragmentary pollen record at San Simon Sink (Wendorf and Hester, 1975 , Wendorf, 1961). As a result of these studied the pollen-climatic history of the Llano Estacado has been subdivided into "pluvial".. "interpluvial!", "subpluvial" " "post pluvial" and related climatic episodes. The underlying concept for such divisions rests chiefly on the relative proportion of arboreal (mostly PINUS) pollen to nonarboreal (herb) pollen. Unfortunately these episodes are not well cated. and they are often so similar palynologically that correlation is difficult. In addition, the inherent variation in pollen profiles that results from differential pollen preservation and variable pollen input makes the detailed interpretations of the pollen record necessarily tentative (Schoenwetter. 1975, Oldfield, 1975, Oldfield and schoenwetter. 1975). a

$$
A-1-3
$$




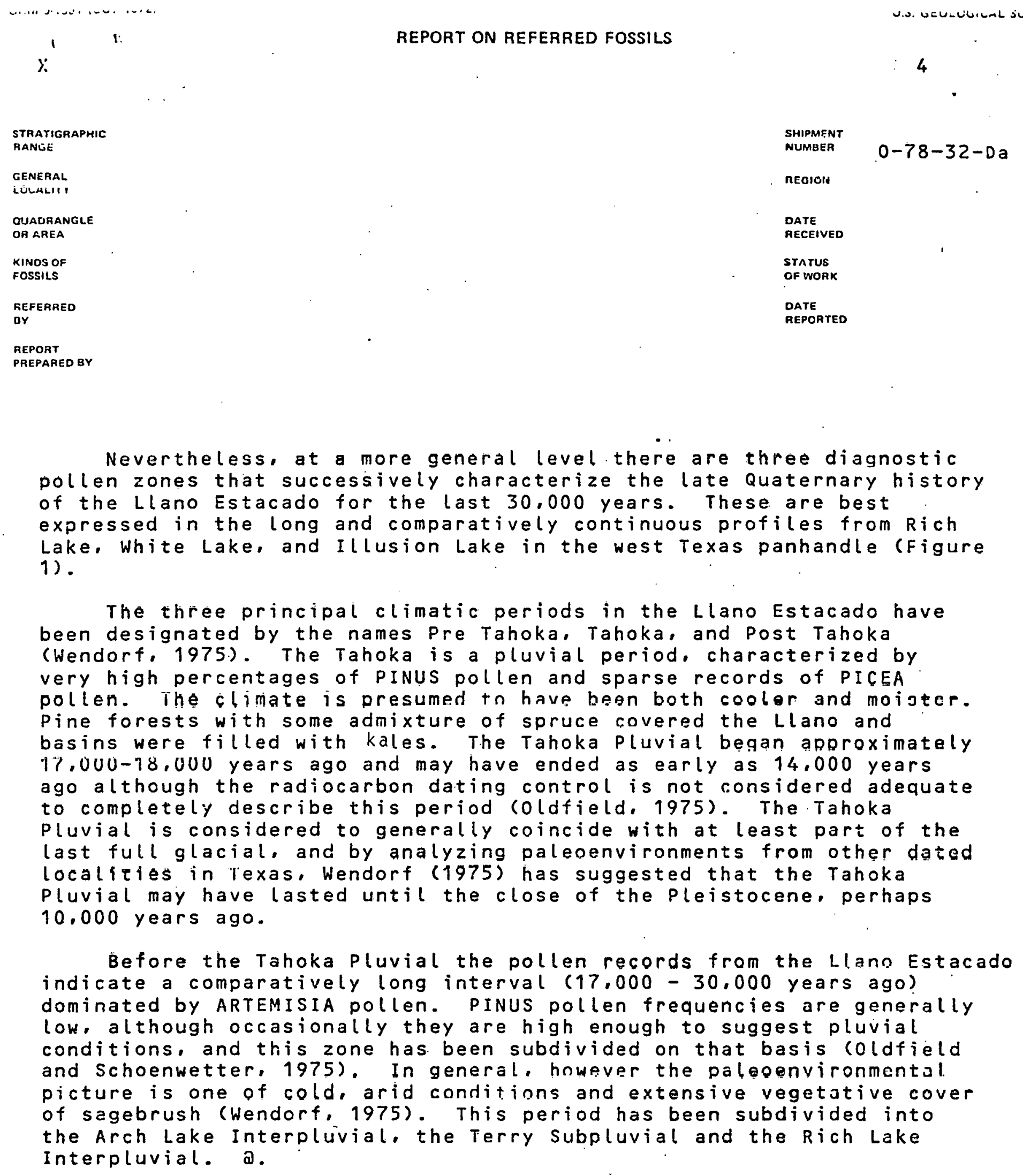

$$
A-1-4
$$




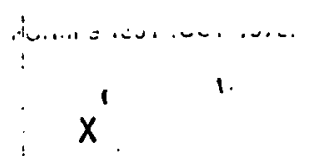

SHIPMENT
NUMBER
REGION
DATE
RECEIVED
STATUS
OF IYORK
DATE
REPORTEO

The post Tahoka period is characterized by a predominance of herbaceous pollen types, principally Chenopodiaceae. Amaranthaceae, Gramineae, and compositae. PINUS pollen is generally low, seldom more than 20 percent, and ARTEMISIA pollen is of reduced importance. approaching modern values for this species. As in the earlier periods. the Post Tahoka has been subdivided on the basis of increased PINUS pollen values into comparatively moister episodes (subpluvials). For the most part, however, the climate of this period is closely comparable to that of the present. The post Tahoka period is generally terminated by erosional truncation in the Llano Estacado and the pollen records seldom extend to modern times. The hiatus is assumed to have occurred during the Altithermal when severe arid conditions reduced vegetation to a point that wind deflation excavated blowouts in old (Tahoka Pulvial) lake deposits. Radiocarbon age control for this event is scarse, but is estimated at between 5000 and 7000 years ago coldfield and Schoenwetter, 1975). The post Altithermal period is too poorly represented in the Llano Estacado to merit much discussion. The few pollen analyses available suggest a return to moister situations and generally modern climatic conditions.

\section{POLLEN STRATIGRAPHY AT SAN SIMON SINK}

The foregoing brief summary of the vegetation and suggested climatic history of the LLano Estacado, makes it possible to interpret the sparse pollen evidence from San simon sink (Figure 3. Table 1). The San Simon sink sediments are often barren of pollen. but the marly silts and $c$ lays in the upper $10 \mathrm{~m}$ were regularly productive. Below that depth only two samples were productive enough to provide interpretable results.

The pollen stratigraphy of san simon sink (Figure 3. Table 1) can be divided into two zones. The uppermost zone $(0.15 \mathrm{~m}$ to $10 \mathrm{~m})$ is dominated by Cheno-Am and compositae pollen and is generally similar to both local and regional modern pollen spectra and to pollen profiles of Holocene age from the Llano Estacado. This part of the San Simon Sink profile contains generally more ARTEMISIA pollen than the modern pollen spectra from the Llano. The ARTEMISIA pollen grains in this section are very degraded, and it is possible that they have been reworked from older deposits in san simon sink, or that their increased representation is a result of differential preservation which has selectively removed the more delicate pollen grains. a 
Despite the anomalously high ARTEMISIA content of the upper part of the San Simon Sink profile, there is little doubt that this section represents Holocene climatic conditions. Nevertheless, it is not inherently obvious how much of the Holocene is represented by this section. There are no radiocarbon dates and although the pollen profiles (Figure 3 ) show some systematic variation that might suggest that a climatic zoning is possible, there are not enough complete Holocene pollen profiles in the Llano Estacado to provide confident correlations. As essentially modern sample from Loving Salt Lake (Figure 1) (Hafsten, 1961) contains percentages of the major pollen types that are very close to the mean values of the upper san simon sink section (Table 3 ), and some additional evidence exists to suggest that the upper $10 \mathrm{~m}$ of the san Simon Sink sediment section represents only the post Altithermal position of the Holocene. First, although there are only a few records, the pre-Altithermal pollen profiles are often characterized by comparatively high PINUS pollen values; between 25 and 50 percent (Hafsten. 1961). Because of this the early Holocene $(10,000$ to 6,000 years ago) has been subdivided into two sub pluvial episodes, the san Jon subpluvial and the Lubbock subpluvial separated by a very brief interval of drier climate (oldfield and Schoenwetter. 1975). The comparatively long and continuous pollen record of the upper sediments at San Simon sink does not contain any samples with comparable PINUS percentages. Second, the San simon sink profile, especially in the basal $5 \mathrm{~m}$, is distinguished by rather high percentages of EPHEDRA pollen. Hafsten (1961) considers EPHEDRA to be one of the most important pollen indicators of exceptionally arid $c$ limate, and the high EPHEDRA percentages at crane Lake are interpreted as representing the most recent fill of this basin. accumulating after 6.000 years ago.

It is general consensus that during the Altithermal the Llano Estacado experienced very arid climates and that lacustrine deposition was replaced by active wind erosion and transportation forming blowouts and sand dunes in many areas of the region (Haynes, 1975). During this time it is unlikely that san simon sink was often the site of pond or lacustrine environments. It is possible that some deflation occurred, removing previously deposited sediments.

CONTINUED ON $0-7.8-32-D G$ a

$$
A-1-6
$$




STRATIGRAPHIC
RANGE
GENEAALL
LOCALITY
QUADRANGLE
OR AREA
KINOS OF
FOSSILS
REFERRED
BY
REPOQT
PREPARED BY

\section{Pleistocene to Holocene}

San Simon Sink, Carlsbad, New Mexico

0il Center, 15 minute quadrangle

pollen, diatoms, ostracodes, Chara, plants

R. Y. Anderson

J. P. Bradbury

$\begin{array}{ll}\begin{array}{l}\text { SHIPMENT } \\ \text { NUMBER }\end{array} & 0-78-32-D b \\ \text { REGION } & \text { Lea county } \\ \begin{array}{l}\text { DATE } \\ \text { RECEIVED }\end{array} & 12 / 07 / 78 \\ \begin{array}{l}\text { STAYUS } \\ \text { OF WORK. }\end{array} & \text { complete } \\ \begin{array}{l}\text { DATE } \\ \text { REPORTED }\end{array} & 12 / 18 / 78\end{array}$

$12 / 18 / 78$

\section{CONTINUED FROM 0-78-32-Da}

At $13.1 \mathrm{~m}$ in the san simon sink sediment section rare PINUS pollen occurs in association with large numbers of the green alga, BOTRYOCOCCUS (Figure 3, Table 1). Although only PINUS pollen has been identified from this level, they are so few in number conly 6 grains on $222 \mathrm{~mm}^{2}$ slides) that assignment of this sample to the Tahoka Pluvial climatic episode where PINUS pollen greatly dominates the lacustrine clays of the Llano Estacado, is speculative. The large numbers of BOTRYococcus testify to the existence of a freshwater lacustrine system in the sink. and this would seem a likely consequence of pluvial climates in the region, however.

Below $13.1 \mathrm{~m}$ the San simon sink sediments are barren of pollen until a depth of $66 \mathrm{~m}$. At this level. two samples. 65.6 and $66.2 \mathrm{~m}$ contain a pollen assemblage that is dominated by ARTEMISIA pollen and large percentages of herbaceous pollen types. Analogues for this type of pollen assemblage in the Llano Estacado first appear during the Rich Lake Interpluvial, tentatively dated between 17,000 and 26,000 years ago (Haynes, 1975). Pollen is abundant and reasonably well preserved in these samples, and it seems reasonable to accept a correlation of these levels with the Rich Lake Interpluvial or perhaps the somewhat earlier Arch Lake Interpluvial (olfield and Schoenwetter. 1975).

OTHER MICROFOSSILS FROM SAN SIMON. SINK

The margins of San simon sink contain extensive outcrops of diatomaceous marls with gastropods, ostracodes, charophytes, and silicified plant remains, particularly sedges. Although the outcrops have not been extensively sampled, the following ecological and climatic information is available concerning these fossiliferous deposits.

Diatoms:

ACHNANTHES AFFINIS

CYCLOTELLA MENEGHINIANA

CYMBELLA PUSILLA

DENTI CULA ELEGANS

EPITHEMIA ARGUS

MASTOGLOIA SMITHII $v$. LACUSTRIS

10 percent
2
11
48
1
1

$$
A-1-7
$$

REPORT NOT TO BE QUOTED OR PARAPHRASED IN PUBLICATION WITHOUT A FINAL·RECHECK BY THE PALEONTOLOGY AND STRATIGRAPHY BMANCH. 
GENEAAL

LOCALITY

REGION

OR AREA

KINOS OF

FOSSILS

REFEGREo

MASTOGLOIA ELLIPTICA V. DANSEI

NAVICULA HALOPHILA $V$. SUBCAPITATA

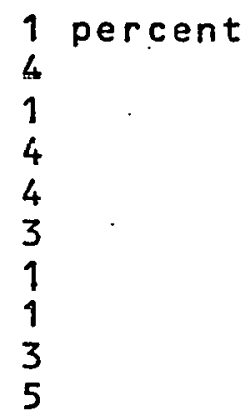

NAVICULA OBLONGA

NAVICULA GRYPTOGEPHALA

NITZSCHIA SUBTILIS

NITZSCHIA OBTUSA $V$. SCHWEINFURTHI

NITZSCHIA AMPHIBIA

NTI\%SLHLA UENIICULA

RHOPALODIA GIBBA

SYNEDRA ACUS?

In addition to these dominants, the following species occured in small numbers:

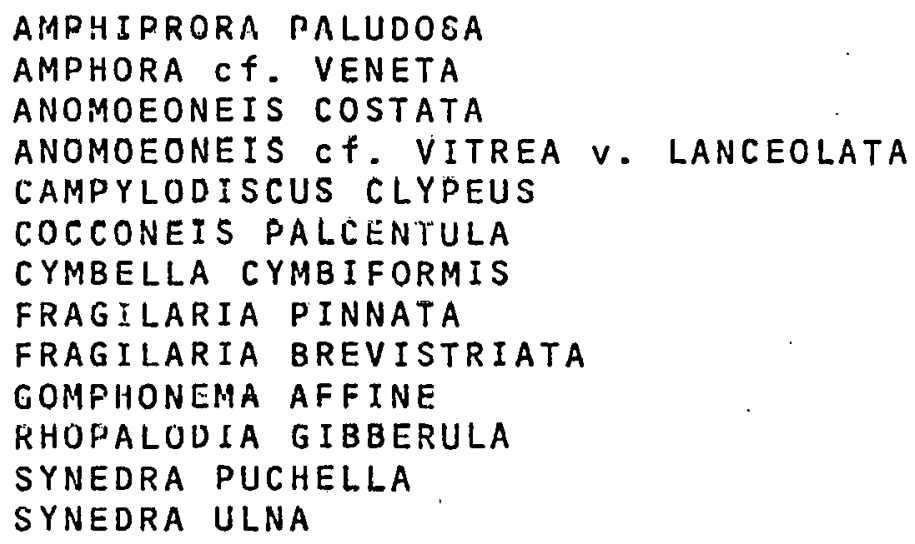

This diatom flora is characteristic of alkaline, brackish water. All the species are either tolerant of moderate concentrations of dissolved solids, or prefer such environments. A close analog of this diatom assemblage can be found at Swimming Pool Spring, Sandoval Co.. New Mexico which had a salinity of about 7 parts per thousand in 1928; many of the same species were also present in the brackish lake that existed at Zuni Salt Lake. Catron Co.. New Mexico in the Late $P l e i s t o c e n e$ or Holocene. Both Swimming Pool Spring and Zuni Salt Lake are or were partly fed by mineralized springs issuing along the fault zones or through subterranean conduits and it seems possible that a similar situation existed at san simon sink. where ground water a 
SHIPMENT

NUMBER

REGION

DATE

RSCEIVED

STATUS

OF WORK

DATE

AEPORTED
$0-78-32-D b$

dissolving subsurface evaporites could supply the necessary amounts of sodium, calcium. chlorine and sulfate ions to support the diatom flora.

Snails: This information was kindly provided by Art Metcalf. University of Texas. El Paso.

Sample A (sample without plant debris):

AQUATIC SPECIES:

Fossariform lymnaeid - 10 specimens

GYRAULUS PARVUS (SaY) - 226

PHYSA VIRGATA GOULd - 410

TERRESTRIAL SPECIES:

PUPILLA BLANDII Gould - 73

Sample A csample with plant debris present. After counting out 200

G. PARVUS, I stopped. There were several hundred more plus some

PHYSA in the sample)

AQUATIIC SPECIES:

Fossariform (ymnaeid cf. FOSSARIA MODICELLA (Say) - 2 GYRAULUS PARVUS - 200

PHYSA VIRGATA - 43

TERRESTRIAL SPECIES:

PUPILLA BLANDII - 31

Sample $B$

AQUATIC SPECIES:

Fossariform lymnaeid - 18

GYRAULUS PARVUS - 32

PHYSA VIRGATA - 165

TERRESTRIAL SPEICES:

Succineid shells, unidentifiable to species - 2

PUPILLA BLANDII - 1 a

$$
A_{1}-1-9
$$

REPORT NOT TO BE QUOTED OR PARAPHRASED IN PUBLICATION WITHOUT A FINAL RECHECK BY THE PALEONTOLOGY AND STRATIGRAPHY BRANCH. 
I was a bit surprised at the lack of diversity in the fauna, compared to that encountered in some other deposits in southeastern New Mexico (such as George Bachman's fauna in Nash oraw). As you can see, the fauna is overwhelmingly aquatic. GYRAULUS PARVUS and PHYSA VIRLATA, as well as some FOSSARIA, tolerate a wide range of habitat situations. However, G. PARVUS is most commonly associated with lotic or slowly flowing waters and is almost always found associated with aquatic vegetation. Spring-fed pools should fill the bill nicely. Both G. PARVUS and P. VIRGATA occur in parts of New Mexico and Texas today, with P. VIRGATA widespread and G. PARVUS more restricted.

PUPILLA BLANDII is not found at lower elevations in southern New Mexico today. Where it is restricted to montane areas above ca. 7.000 $\mathrm{ft}$. elevation. In northeastern New Mexico it occurs in grasslands above some 6.000 feet. especially along creeks and pools. For example it occurs in tall grass bordering the small creek just west of springer. colfax county. I suspect that it has not occurred in the san simon area during most of the Holocene.

Ostracodes and charophytes: Information provided by R. M. Forester. U.S.G.S.

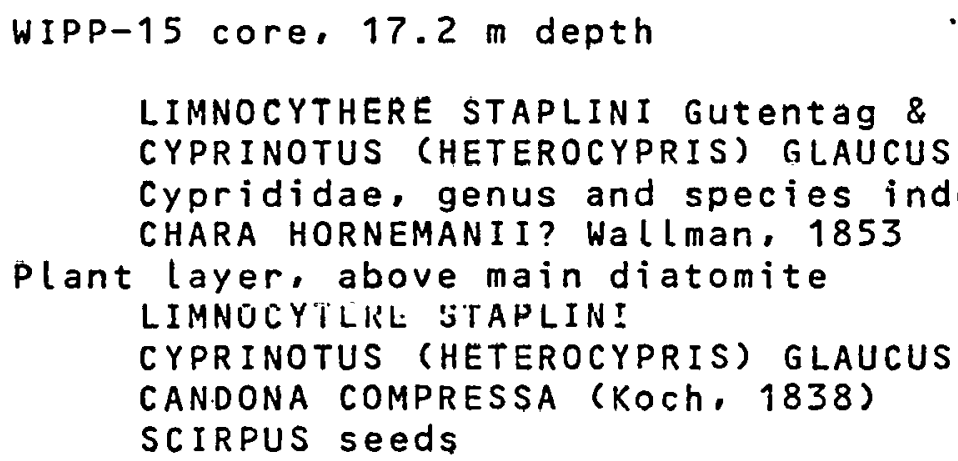


STRATIGRAPHIC

RANGE

GENERAL

LOCALITY

QUADRANGLE

OR AREA

KINDS OF

FOSSILS

REFERRED

BY

REPORT

PAEPARED BY
SHIPMENT

NUMBEA

$0-78-32-D b$

REGION

DATE

RECEIVED

STATUS

OF WOAK

DATE

REPOATED

San Simon B. Lateral equivalent to diatomite LIMNOCYTHERE STAPLINI

CYPRINOTUS (HETEROCYPRIS) GLAUCUS

POTAMOCYPRIS SP. indet.

CHARA HORNEMANII?

San Simon A VI marls below diatomite

LIMNOCYTHERE STAPLINI

CYPRINOTUS (HETEROCYPRIS) GLAUCUS

CANDONA.sp. (juveniles)

Cyprididae genus and species indeterminate

CHARA HORNEMANII?

CHARA SP. CF. CHARA CANESCENS

All the samples contain essentially the same ostracode fauna and charophyte flora, and although there are minor differences in the frequencies of species present: LIMNOCYTHERE STAPLINI dominates in each sample. This ostracode is most commonly found in very shallow (less than $2 \mathrm{~m}$ depth) water that ranges in salinity from less than $10 / 00$ to as much as $2000 / 00$. It is a species that is often found in ponds or playa systems of arid regions where it hatches during the rainy season and breeds before the system dries up. We have found it in the salt marshes in Death Valley, California for example.

The subdominant ostracode, CYPRINOTUS (HETEROCYPRIS) GLAUCUS, Lives in fresh to slightly saline water often within the range of 0.5 to 10 or $120 / 00$. I believe its presence with LIMNOCYTHERE STAPLINI and the absence of a typcial freshwater assemblage implies that this habitat had a salinity of about 3 to $100 / 00$, was very shallow (perhaps occasionally desiccating) and alkaline. Aquatic vegetation was locally abundant. The other ostracodes, present in low abundance, suggest the presence of freshwater (less than 3 o/oo) nearby and perhaps a cooler climate than present.

The same calcareous and siliceous microfossils sparsely occur in the WIPP-15 core samples to a depth of $27.6 \mathrm{~m}$. Although the microfossils are often well preserved, they are never as common in the core as they are in the marginal outcrops of the sink. Several lines of evidence suggest that at least some of these fossils have been reworked from the marginal outcrops into the center of the sink where the core was taken after a phase of collapse that deepened the basin. a 
SMIPMENT NUMBEA

REGION

$0-78-32-0 b$

DATE

RECEIVED

STATUS

OF WOAK

DATE

REPORTED

The greatest abundance of microfossils occurs in the upper $10 \mathrm{~m}$ of lhe cure where they are associated with a Holocene pollen assemblage. The best paleoenvironmental information that relates to the diatomaceous marls comes from the presence of PUPILLA BLANDII which Metcalf indicates is restricted to cool. mofst environments above 7,000 feet in this part of New Mexico today. If this type of habitat applies generally to the diatomaceous marls on the sink margins, then it should also apply to the occurrence of the same mirrofossils in the WIPP-15 corc. such an environment existed on the Llano Estacado during the Tahoka Pluvial, tentatively dated between 13.000 and 20.000 years ago (HAYNES, 1975), and probably correlating with the terminal Wisconsin glacial event. Pollen evidence for the Tahoka Pluvial on the Llano Estacado consists of an extreme dominance of coniferous arboreal pollen (spruce and pine) that suggests a depression of vegetation zones of about 4000 feet coldfield and Schoenwetter, 1975). San Simon sink (elevation 3300 feet) would have had an environment analoguous to elevations in southern New Mexico of about 7,000 feet. The pollen assemblage in the core however, indicates a Holocene age and is in conflict with the assumed environmental conditions relating to the calcareous and siliceous microfossils. A radiocarbon date on the snails from the marginal diatomaceous marls of 20,520 years BP is consistent with their environmental interpretation. and it seems quite probable that at least the top $10 \mathrm{~m}$ of the WIPP-15 core consists largely of reqorked Tahoka Pluvial lake or pond sediments that were redeposited during the Holocene.

It is curious that with the exception of one sparse pollen sample that merits only speculative interpretation $(13.1 \mathrm{~m})$ there is no pollen evidence of the Tahoka Pluvial climate in the WIPP-15 core. Perhaps the sparse representation of calcareous and siliceous microfossils between 10 and $27.6 \mathrm{~m}$ were deposited in place during this period of time. They are so sparse, however, and often in very sandy lithologies, that it is difficult to immagine they were deposited by normal lacustrine depositional processes.

CONTINUED ON $0-78-32-D C$ a

$$
A-1-12
$$


STRATIGRAPHIC RANGE

GENERAL

LCCALITY

guAdRANGLE

OR AREA

KINDS OF

FOSSILS

REFERRED

BY

REPOAT

PREPARED BY
Pleistocene to Holocene

San Simon Sink, Carlsbad, New Mexico

oil Center, 15 minute quadrangle

pollen, diatoms, ostracodes, chara, plants

R. $Y$. Anderson

J. P. Bradbury
1.

$\begin{array}{ll}\begin{array}{l}\text { SHIPMENT } \\ \text { NUMBER }\end{array} & 0-78-32-D C \\ \text { REGION } & \text { Lea County } \\ \begin{array}{l}\text { DATE } \\ \text { RECEIVED }\end{array} & 12 / 07 / 78 \\ \begin{array}{l}\text { STATUS } \\ \text { OF WORK }\end{array} & \text { complete } \\ \begin{array}{l}\text { DATE } \\ \text { REPORTED }\end{array} & 12 / 18 / 79 \\ & \end{array}$

CONTINUED FROM $0-78-32-D b$

Under pluvial environments, the center of the sink should have been filled with fine-grained clayey. marls, which would have likely contained pollen. Perhaps the pollen, and many of the calcareous and siliceous microfossils. were deposited in this way during the Tahoka Pluvial but were subsequently destroyed by solution and oxidation accompanying post Tahoka collapse events. It is also possible that the san simon basin that existed during Tahoka time was sufficiently offset from the sink center that exists today that the spot where the WIPP-15 core was taken was outside the area of normal lacustrine deposition. A third possibility is that during the Tahoka Pluvial San Simon Sink was an active limnokrene from which water flowed away from the spring pool itself. In such a situation, fine sediment containing pollen and other microfossils might not accumulate in the center of the spring but be restricted to the marginal areas where shallow water and emergent vegetation reduced the flow enough for fossiliferous deposits to build up. The considerably increased percipitation associated with the Tahoka Pluvial (Oldfield and Schoenwetter, 1975) may have been partly responsible for the development of a limnokrene at San simon sink. A limnokrene environment is consistent with the abundance of GYRALUS PARVUS reported by Metcalf and with the diatom association. although the diatoms are not restricted to such environments.

At the time the diatomaceous marls accumulated on the present margins of the sink. San simon sink may have been higher than at present and the water could have flowed along San simon swale to the southeast. The presence of diatomaceous marls nearly $25 \mathrm{~m}$ above the modern playa floor suggests this possibility, although it is difiicult to reach firm conclusions about the Pleistocene topography of the sink and swale because there has been so much recent collapse. a

$$
A-1-13
$$


STRATIGRAPHICC

RANGE

GENERAL

LUCALIT':

OUÁORANGLE

OR AREA

KINDS OF

FOSSILS

AEFERRED

SHIPMENT
NUMBER
REGION
DATE
RECEIVEO
STATUS
OF WORK
DATE
REPORTED

Unfortunately the available information about the WIPP-15 core and the marginal deposits in san simon sink does not make it easy to refine the paleolimnological interpretation and to choose between the three possible alternatives outlined above. It is nevertheless clear that during the Tahoka Pluvial, perhaps as recently as 10,000 years ago (Wendorf, 1975) and certainly after 20.000 years ago. San Simon sink was filled with water. Filling was probably partly a result of normal increases in precipitation and runoff associated with cooler and moister climates, and partly from inflow from subterranean aquifers under hydrostatic pressure. The Permian reef complex beneath the sink is a good candidate for such an aquifer.

The direct and indirect relationship between pluvial climates, hydrology, and dissolution of underlying Permian salt beds have important implications regarding the integrity of this area for storage of nuclear wastes.

\section{REFERENCES CITED}

Hafsten, U., 1961. Pleistocene development of vegetation and climate in the southern High Plains as evidenced by pollen analysis ( $p$. 59-9i) in Wendorf, D. F.. 1961 (ed), Paleoecology of the Llano Estacado: Publication no. 1. Fort Burgwin Research C'enter. Museum of New Mexico Press, Santa Fe, $144 \mathrm{p}$.

Haynes, C. V.. 1975, Pleistocene and recent stratigraphy (p. 57-102) in Wendorf, D. F.. and Hester, J. J. (eds.), 1975, Late Pleistocene environments of the southern High Plains: Publication no: 9. Fort Burgwin Research Center. Southern Methodist University, $290 \mathrm{p}$.

oldfield. F.. 1975, Pollen analytical results, part 2 (p. 121-148) in Wendorf, U. F.. and Hester, J.J. (eds.), 1975, Late Plelstocene environments of the southern tigh Plains: Publication no. 9. For: Burgwin Research Center. Scuthern Methodist University, $290 \mathrm{p}$.

oldfield. F.. and Schoenwetter. J.. 1975. Discussion of the pollen analytical evidence (p. 149-178) in Wendorf, D. F.. and Hester, J. J.. 1975 (eds.), Late Pleistocene environments of the southern High Plains: Publication no. 9. Fort Burgwin Research Center. Southern Methodist University, 290 p. a

$$
\text { A }-1-14
$$


STRATIGRAPHIC

RANGE

GENERAL

LOCALITY

QUADRANGLE

OP AREA

KINDS OF

FOSSILS

REFERAED

BY

REPORT

PREPARED BY

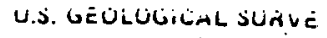

SHIPMENT

NUMBEA

$0-78-32-D C$

REGION

DATE

AECEIVED

status

OF WORK

DATE

REPOATED

Schoenwetter, J.. 1975. Pollen analytical results, part 1 (p. 103-120) in Wendorf, D. F., and Hester, J.J. (eds.), 1975, Late Pleistocene environments of the southern High Plains: Publication no. 9,

Fort Burgwin Research Center, Southern Methodist University, $290 \mathrm{p}$.

Wendorf, D. F.. 1961. An interpretation oi late Pleistocene environments of the Llano Estacado (p. 115-133) in Wendorf, D. F. (ed.). 1961. Paleoecology of the Llano Estacado: Publication no. 1. Fort Burgwin Research Center. Museum of New Mexico Press, Santa Fe, 144 p. Wendorf, D. F.. 1975, Summary and conclusions (p. 257-279) in Wendorf, D. F.. and Hester, J. J. (eds.), 1975, Late Pleistocene environments of the southern High Plains: Publication no. 9. Fort Burgwin Research Center. Southern Methodist University. $290 \mathrm{p}$.

Wendorf, D. F.. and Hester (eds.), 1975, Late Pleistocene environments of the southern High Plains: Publication no. 9, Fort Burgwin Research Center. Southern Methodist University, $290 \mathrm{p}$. 


STAATIGRAPHIC
AANGE
GENERAL
LOCALITY
QUADRANGLE
OR AREA
KINOS OF
FOSSILS
REFERRED
BY
REPORT
PREPARED BY

Sample No.

Depth or location

Pollen

PINUS

EPIIEDRA

JUNIPERUS

QUERCUS

Compositae

ARTEMISIA

Cheno Am 3

Gramineae

ULMUS

TAMARIX

ERIOGONUM

PROSOPIS

TYPHA

JUGLANS

Labiateae

BETULA

ALNUS

SALIX

CELTIS

Polygonaceae

Malvaceae

CARYA

LI liaceas

Moraceae

ALTERNANTHERA

Algae

PEDIASTRUM

BOTYROCOCCUS
SHIPMENT

NUMBEH

$0-78-32-D C$

REGION

DATE

RECEIVED

STATUS

OF WORK

DATE

REPORTED
D. -5966

Woodwell Tank

no: 1

109 grains

$D-5967$

Woodwell Tank

no. 2

130 grains

211 grains
Pnllen irap

3-8/3-10 78

1

$-$

52

15

$23 \quad 20.5$

2

22

10

0.8

$-$

$-$

6

0.8

0.8

1.5

0.8

$-$

0.8

$-$

$-$

$-$

-

-

$-$

0.8
2

8

6

1.5

$-$

$-$

-

$-$

$-$

$-$

0.5

$-$

1

0.5

0.5

0.5

$-$

$-$

-

-

$$
\text { A- } 1-16
$$


itratigRAPHIC

?ANGE

GENERAL

LOCALITY

QUADRANGLE

OR AREA

KINDS OF

FOSSILS

REFERRED

BY

REPORT

PREPARED BY
Sample No.

Depth or location

Pollen

PINUS

EPHEDRA

JUNIPERUS

QUERCUS

Compositae

ARTEMISIA

Cheno-Am

Gramineae

ULMUS

TAMARIX

ERIOGONUM

PROSOPIS

TYHPA

JUGLANS

Labiateae

BETULA

ALNUS

SALIX

CELTIS

Polygonaceae

Malvaceae

CARYA

Liliaceae

Moraceae

ALTERNANTHERA

Algae

PEDIASTRUM

BOTYROCOCCUS
SHIPMENT

NUMBEA

$0-78-32-D C$

REGION

DATE

ReceIved

STATUS

OF WOAK

DATE

REPOATED
D5969.

Pollen Trap Pollen Trap

$3-13 / 3-1778$ 210 grains

7

2

27

15

21

4

14

3.5

4

0.5

$-$

$-$

$-$

-

$-$

-

$\overline{0.5}$

$-$

$-$

0.5

0.5

0.5

$-$
D5971

Drilling

Mud

17 III 1978

45 grains
11

3.3

59

5

16.

1.4

4.3

2.4

6

1

$-$

$\overline{-}$

$-$

$\overline{-}$

$\overline{0.5}$

$-$

$-$

$-$

-

-

-
2

2

22

13

26

18

$-$

-

$-$

-

-

$-$

$-$

$-$

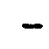

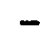

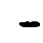

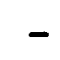

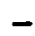

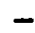

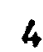

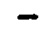

$$
\text { A- } 1-17
$$




STRATIGRAPHIC
RANGE
GENERAL
LOCALITY
QUADRANGLE
ORAREA
KINDS OF
FOSSILS
REFERRED
BY
REPORT
PREPARED BY

PREPARED BY

\begin{tabular}{|c|c|c|c|c|c|}
\hline $\begin{array}{l}\text { Sample no. } \\
\text { Depth or location }\end{array}$ & $\begin{array}{l}06049-Q \\
0.15 \mathrm{~m} \\
211 \mathrm{gr}\end{array}$ & $\begin{array}{l}D 6049-\mathrm{P} \\
0.64 \mathrm{~m} \\
200 \mathrm{gr}\end{array}$ & $\begin{array}{l}\mathrm{D} 6049-0 \\
1.2 \mathrm{~m} \\
204 \mathrm{gr} .\end{array}$ & $\begin{array}{l}D 6049-\mathrm{N} \\
2.2 \cdot \mathrm{m} \\
86 \mathrm{gr}\end{array}$ & $\begin{array}{l}D 6049-M \\
3.0 \mathrm{~m} \\
206 \mathrm{gr} .\end{array}$ \\
\hline \multicolumn{6}{|l|}{ Pollen } \\
\hline PINUS & 12 & 13 & 18.5 & 3 & 10 \\
\hline EPHFחRA & 1 & 2.5 & 2 & 1 & 3.5 \\
\hline $\begin{array}{l}\text { JUNIPERUS } \\
\text { QUERCUS }\end{array}$ & $\begin{array}{l}4 \\
5\end{array}$ & $2^{5} \cdot 5$ & $\begin{array}{l}2.5 \\
5\end{array}$ & $\frac{-}{2}$ & 0.5 \\
\hline $\begin{array}{l}\text { Compositae } \\
\text { ARTEMISIA }\end{array}$ & $\begin{array}{l}21 \\
11\end{array}$ & $\begin{array}{l}27.5 \\
9\end{array}$ & $\begin{array}{l}29 \\
8\end{array}$ & $\begin{array}{l}29 \\
22\end{array}$ & $\begin{array}{l}20.5 \\
15\end{array}$ \\
\hline $\begin{array}{l}\text { Cheno-Ams } \\
\text { Gramineae }\end{array}$ & $\begin{array}{l}26 \\
9\end{array}$ & $\begin{array}{l}26.5 \\
8\end{array}$ & $\begin{array}{l}18.5 \\
14\end{array}$ & $\begin{array}{l}12 \\
28\end{array}$ & $\begin{array}{l}21 \\
19\end{array}$ \\
\hline ULMUS & 0.5 & - & - & $=$ & - \\
\hline TAMAR IX & - & - & - & - & - \\
\hline ERIOGONUM & - & - & - & - & \\
\hline PRUSDPIS & - & - & - & - & - \\
\hline TYPHA & $=$ & $=$ & - & - & 1 \\
\hline JUGLANS & 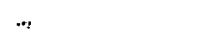 & - & - & $=$ & 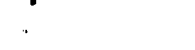 \\
\hline Labiateae & 0.5 & - & - & - & - \\
\hline BETULA & - & - & 0.5 & - & - \\
\hline ALNUS & - & - & 0.5 & - & - \\
\hline SALIX & 1 & - & 1 & - & - \\
\hline C.ELTTS & - & - & - & - & - \\
\hline Polygonaceae & 0.5 & 1 & 1.5 & - & $\dot{-}$ \\
\hline Malvaceae & - & 0.5 & - & - & - \\
\hline CARYA & - & $-\quad$. & - & - & - \\
\hline Liliaceae & 3 & 2.5 & 0.5 & 2 & - \\
\hline Moraceae & 0.5 & $-=$ & - & $\therefore$ & $=$ \\
\hline ALTERNANTHFRA & 1 & - & 0.5 & - & 1 \\
\hline \multicolumn{6}{|l|}{ Algae } \\
\hline PEOIASTRUM & - & - & - & - & - \\
\hline BOTYROCOCCUS & 3 & 2 & 1 & 1 & 2 \\
\hline CONTINUED ON $0-78-32-D d$ & a & & & & \\
\hline
\end{tabular}




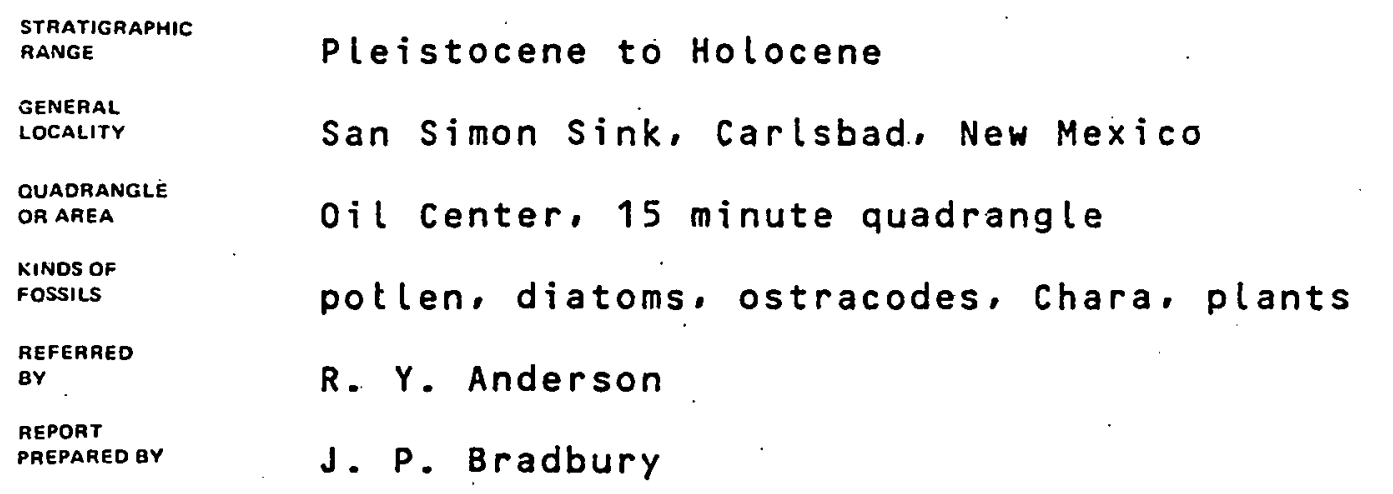

$\begin{array}{ll}\begin{array}{l}\text { SHIPMENT } \\ \text { NUMBER }\end{array} & 0-78-32-\mathrm{dd} \\ \begin{array}{l}\text { REGION } \\ \text { Lea County }\end{array} & \text { Lea } \\ \begin{array}{l}\text { PECEIVED } \\ \text { STATUS }\end{array} & 12 / 07 / 78 \\ \text { OF WORK } & \text { complete } \\ \begin{array}{l}\text { DATE } \\ \text { REPORTED }\end{array} & 12 / 18 / 79\end{array}$

CONTINUED FROM 0-78-32-DC

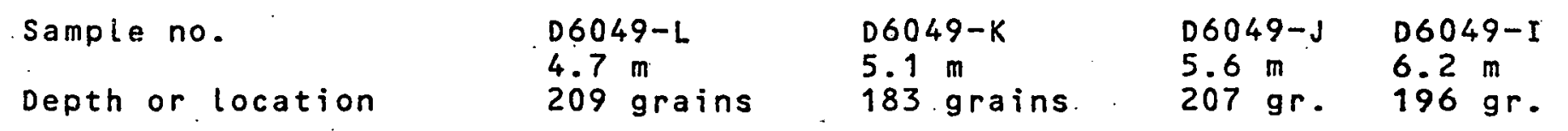

Pollen

PINUS

EPHEDRA

JUNIPERUS

QUERCUS

Compositae

ARTEMISIA

Cheno-Ams

Gramineae

ULMUS

TAMAR I $X$

ER IOGONUM

PROSOPIS

TYPHA

JUGLANS

Labiateae

BETULA

ALNUS

SALIX

CELTIS

Polygonaceae

Malvaceae

CARYA

Li liaceae

Moraceae

ALTERNANTHERA

A lgae

PEDIASTRUM
BOTYROCOCCUS

PEDIASTRUM
BOTYROCOCCUS

$\begin{array}{ll}5.5 & 11 \\ 4.5 & 4 \\ 1 & 0.5 \\ 4 & 7 \\ 30.5 & 20.5 \\ 14 & 9 \\ 20 & 24 \\ 18 & 14 \\ - & - \\ - & - \\ - & - \\ - & - \\ - & - \\ 1 & - \\ - & - \\ - & - \\ - & - \\ - & - \\ 1.5 & - \\ - & - \\ - & - \\ - & 0.5\end{array}$

$\begin{array}{ll}6 & 5 \\ 11 & 9 \\ 1 & 0 \\ 1 & \end{array}$

5

9

0.5

1

3.5

$23.5 \quad 28.5$

11

12.5

16.5

18

$18 \quad 18$

$-$

$-$

-

$-$

$-$

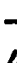

4

$-$

$-$

-

$-$

$-\overline{1.5}$

- $\quad-$

- $\quad-$

-

$\overline{-} \quad \overline{1}$

$\overline{0} \quad \overline{0} .5$

$-1$

8

a 


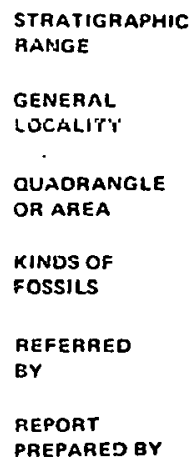

Sample no.

Depth or location Pollen

\section{PINUS}

EPHEDRA

JUNI PERUS

QUERCUS

Compositae

ARTEMISIA

Clieilu-Alis

Gramineae

ULMUS

TAMARIX

ERIOGONUM

PROSOPIS

TYPHA

JUGLANS

Labiateae

BETULA

ALNUS

SALIX

CELTIS

Polygonaceae

Malvaceae

CARYA

Liliaceae

Moraceae

ALTERNANTHERA

Algae

PEDIASTRUM

BOTYROCOCCUS
D6049.-H

$6.9 \mathrm{~m}$

100 grains

D6049-G

$7.1 \mathrm{~m}$

198 grains

3.5
7.5
-1
29
12
13
31

31

-

$-$

$-$

$-$

$-$

$-$

$-$

$-$

..

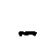

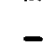

$-$

$-$

1

-

$-$

3
SHIPMENT

NUMBER

$0-78-32-0 d$

RErinN

DATE

RECEIVED

STATUS

OF WORK

DATE

AEPORTED
D6049-F D6049-E

$8.1 \mathrm{~m} \quad 9.1 \mathrm{~m}$

$206 \mathrm{gr} .200 \mathrm{grains}$ 
STRATIGRAPHIC RANGE

\section{GENERAL}

LOCALITY

QuADaANGLE

OR AAEA

KINOS OF

FOSSILS

REFERRED

BY

REPORT

PREPARED BY
SHIPMENT NUMBEA

REGION

DATE

RECEIVED

STATUS

OF WORK

DATE

Reponted

D6049-C

$13.1 \mathrm{~m}$

6 grains

D6049-B

D6049-A

$10.1 \mathrm{~m}$

206 grains

$65.6 \mathrm{~m}$

$206 \mathrm{gr}$.

$66.2 \mathrm{~m}$

267 grains

Pollen

PINUS

EPHEDRA

JUNIPERUS

QUERCUS

Compositae

ARTEMISIA

Cheno-Ams.

Gramineae

ULMUS

TAMARIX

ERIOGONUM

PROSOPIS

TYPHA

JUGLANS

Labiateae

BETULA

ALNUS

SALIX

CELTIS

Polygonaceae

Malvaceae

CARYA

Liliaceae

Moraceae

$-$

$-$

$-$

$-$

ALTERNANTHERA

Algae

PEDIASTRUM

BOTYROCOCCUS
3

11

2

2

23

14

27

18

$-$

-

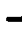

0.5

$-$

-

-

0.5

0.5

100

-

$-$

-

$-$

$-$

-

-

-

$-$

-

-

-

-

-

-

$-$

-

-

$-$

$-$

-

$-$

27
3.5

4

0.5

18

31

15

26

$-$

-

$-$

$-$

$-$

$-$

-

$-$

$-$

-

-

$-$

-

-

-

$-$

0.5
$0-78-32-D d$
198 a
4 .

0.3

9

1.

46

6

20

1.5

$-$

-

-

0.3 
STRATIGRAPHIS.

RANGE

GENERAL

LCCALITY

QuAORANGLE

OR AREA

KINDS OF

FOSSILS

REFEAREO

BY

REPORT

PREPARED BY
SHIPMENT

NUMAER $0-78-32-D d$

REGION

DATE

RECEIVEO

STATUS

OF WOHK

DATE

REPORTED

DISTRIBUTION OF MICROFOSSILS IN SAN SIMON SINK CORE, WIPP-15

depth in meters
$0.15 \quad 0.64 \quad 1.1$
1.6
$2.2 \quad 2.6$
3.0
4.7
5.1
5.6

Diatoms

AMPHORA COFFAEIFORMIE

AMPHORA SP. Cf. A. HYALINA

ANOMOEONEIS COSTATA

A. SPHAEROPHORA

CAMPYLODISCUS CLYPEUS

COCONNEIS PLACENTULA

CYCLOTELLA MENEGHINIANA

CYMBELLA PUSILLA

DENTI CULA ELEGANS

EPITHEMIA ADNATA

E. ARGUS

FRACILARIA

BREVISTRIATA

F. CONSTRUENS $V$. SUBSALINA

F. CONSTRUENS $V$. VENTER

F. VIRESCENS

MASTOGOLIA BRAUNII

M. ELLIPTICA

NITZSCHIA SDP.

PINNULARIA MICRO-

STARURON

RHOPALODIA GIBBA

$R$. GIBBERULA

CHARA

Ostracodes

CANDONA SP.

CYPRIDEIS SP.

LIMNOCYTHERE STAPLINI

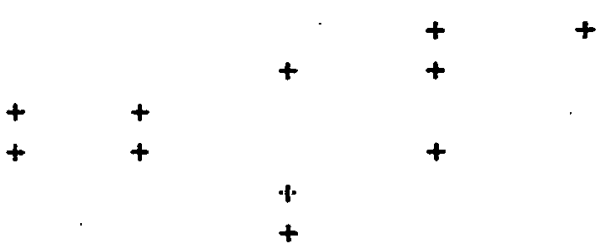

Snails

$\begin{aligned} & + \\ & + \\ & +\end{aligned}+$
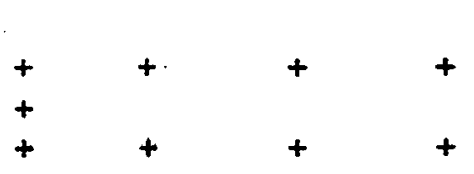

$+$

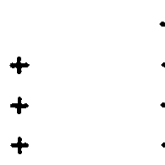

+
+
+
+

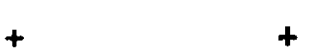

$+$

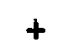

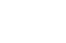
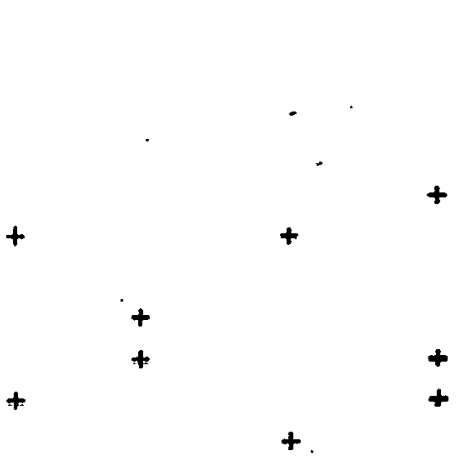

Plant remians

$A-1-22$

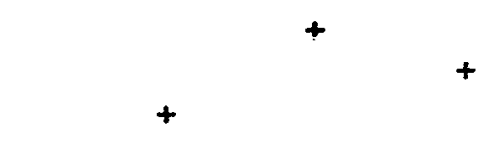

REPORT NOT TO BE QUOTED OR PARAPHRASED IN PUBLICATION WITHOUT A FINAL RECHECK BY THE PALEONTOLOGY AND STRATIGRAPHY BRANCH. 
STRATIGRAPHIC

RANGE

GENERAL

LOCALITY

QUADAANGLE

OR AREA

KINDS of

FOSSILS

REFEAREO
BY

REPORT

PREPAAED BY

DISTRIBUTION OF MICROFOSSILS IN SAN SIMON SINK CORE, WIPP-15

depth in meters
6.2
6.9
$7.1 \quad 7.6$
8.1
8.6
9. 1
9.6
10. 1
10.6

AMPHORA COFFAEIFORMIS

AMPHORA SP. Cf. A. HYALINA

ANOMOEONEIS COSTATA

A. SPHAEROPHORA

CAMPYLODISCUS CLYPEUS

COCCONEIS PLACENTULA

CYCLOTELLA MENEGHINIANA

CYMBELLA PUSILLA

DENTICULA ELEGANS

EPITHEMIA ADNATA

E. ARGUS

FRAG ILARIA

BREVISTRIATA +

F. CONSTRUENS $V$. SUBSALINA

F. CONSTRUENS $V$. VENTER

F. VIRESCENS

MASTOGOLIA BRAUNII

M. ELLIPTICA

NITZSCHIA SPP.

PINNULARIA MICROSTAURON

RHOPALODIA GIBBA

R. GIBBERULA

CHARA

Ostracodes

CANDONA SP.

CYPRIDEIS SP.

LIMNOCYTHERE STAPLINI

Snails

Plant romains 


\section{depth in meters \\ $\begin{array}{lllllllll}11.1 & 11.6 & 12.1 & 12.6 & 13.1 & 13.6 & 14.1 & 14.7 & 15.1\end{array}$}

Diatoms

AMPIIORA COFFAEIFORMIS

AMPHORA SP. CF. A. HYALINA

ANOMOEONEIS COSTATA

A. SPHAEROPHORA

CAMPYLODI 3 CU3 CLYPEU 3

COCCONEIS PLACENTULA

CYCLOTELLA MENEGHINIANA

CYMBELLA PUSILLA

DENTICULA ELEGANS

EPITHEMIA ADNATA

E. ARGUS

$+$

FRAGILARIA

BREVI3TRIATA +

F. CONSTRUENS V. SUBSALINA

F. CONSTRUENS $V$. VENTER

F. VIRESCENS

IASTUGLOIA BRAUN 1

M. ELLIPTICA

NITZSCHIA SPP. +

PINNULARIA MICROSTAURON

RHOPALODIA GIBBA

\section{CHARA}

Ostracodes

CANDONA SP.

CYPRIDEIS SP.

LIMNOCYTHERE

STAPLINI

Snails

Plant remains

CONTINUED ON $0-78-32-D e$ a 
STRATIGRAPHIC

GENERAL

LOCALITY

QUADRANGLE

OR AREA

KINDS OF

FOSSILS

REFEARED

BY

REPOAT

PREPARED BY
Pleistocene to Holocene

San Simon Sink, Carlsbad, New Mexico

oil Center, 15 minute quadrangle

pollen, diatoms, ostracodes, Chara, plants

R. $Y$. Anderson

J. P. Bradbury
SHIPMENT

NUMBER

REgION

OATE

RECEIVED

STATUS

OF. WORK

DATE

REPORTEO
$0-78-32-0 e$

Lea County

$12 / 07 / 78$

complete

$12 / 18 / 79$

CONTINUED FROM 0-78-32-Dd

DISTRIBUTION OF MICROFOSSILS IN SAN SIMON SINK CORE, WIPP-15

Diatoms

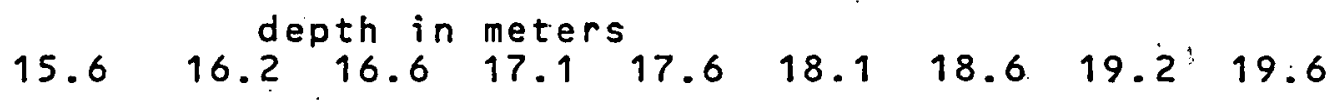

AMPHORA COFFAEIFORMIS

AMPHORA SP. CF. A. HYALINA

ANOMOEONEIS COSTATA

A. SPHAEROPHORA

CAMPYLODISCUS CLYPEUS

COCCONEIS PLACENTULA

CYCLOTELLA MENEGHINIANA

CYMBELLA PUSILLA

DENTICULA ELEGANS

EPITHEMIA ADNATA

E. ARGUS

FRAGILARIA BREVISTRIATA

F. CONSTRUENS $V$. SUBSALINA

F. CONSTRUENS V. VENTER

F. VIRESCENS

MASTOGLOIA BRAUNII.

M. ELLIPTICA

NITZSCHIA SPP.

PINNULARIA MICROSTAURON

RHOPALODIA GIBBA

R. GIBBERULA

CHARA

Ostracodes

CANDONA SP.

CYPRIDEIS SP.

LIMNOCYTHERE STAPLINI

Snails

Plant remains

a

$$
\text { A }-1-25
$$

REPORT NOT TO BE QUOTED OR PARAPHRASED IN PUBLICATION WITHOUT A FINAL RECHECK BY THE PALEONTOLOGY AND STRATIGRAPHY BRANCH. 


STRATIGAAPHIC
RANGE
GENERAL
LOCAIITY
OUADRANGLE
OR AREA
KINDS OF
FOSSILS
REFERRED
BY
REPORT
PREPARED BY

SHIPMENT
NIMMEER
nCOION
OATE
RECEIVED
STATUS
OF WORK
DATE
REPORTED

DISTRIBUTION OF MICROFOSSILS IN SAN SIMON SINK CORE, WIPP-15

Diatoms

$$
\begin{array}{lllllllll}
19.8 & 22.1 & 22.6 & \text { depth in meters } & & \\
& 22.8 & 23.6 & 24.6 & 25.6 & 26.6 & 27.6
\end{array}
$$

AMPHORA COFFAEIFORMIS

AMPHORA SP. Cf. A. : HYALINA

ANOMOEONEIS COSTATA

A. SPHAEROPHORA

CAMPYLODISCUS CLYPEUS

COCCONEIS PLACENTULA

CYCLOTELLA MENEGHINIANA

CYIABELLA PUSILLA

DENTI CULA ELEGANS

EPITHEMIA ADNATA

E. ARGUS

FRAGILARIA BREVISTRIATA

F. CONSTRUENS $V$. SUBSALINA

F. CONSTRUENS V. VENTER

F. VIRESCENS

MASTOGOLIA BRAUNII

M. ELLIPTICA

NITZSCIIIA SNH.

PINNULARIA MICROSTAURON

RHOPALODIA GIBBA +

R. GIBBERULA

\section{CHARA}

Ostracodes

CANDONA SP.

CYPRIDEIS SP.

LIMNOCYTHERE STAPLINI

Snails

Plant remairis

a

$$
\text { A- } 1-26
$$


GENERAL

LOCALITY

REGION

QUADRANGLE

CR AREA

DATE

KINOS OF

FOSSILS

REFERREO

BY

REPORT

PREPARED BY

RECEIVED

STATUS

OF WORK

DATE

REPORTED

\begin{tabular}{|c|c|c|c|c|c|c|c|c|c|}
\hline & \multicolumn{2}{|c|}{ Woodwell } & Tank & & & Pollen & traps. & March & 1978 \\
\hline $\begin{array}{l}\text { PINUS } \\
\text { ephedra } \\
\text { EPHEDRA }\end{array}$ & $\begin{array}{l}1 \\
5 \\
0\end{array}$ & $\begin{array}{l}2 \\
4 \\
4\end{array}$ & $\begin{array}{l}\bar{x} \\
4.5 \\
0\end{array}$ & $\begin{array}{l}12.5 \\
3.0^{5}\end{array}$ & & $\begin{array}{c}8-10 \\
1 \\
0\end{array}$ & $\begin{array}{c}13-17 \\
7 \\
2\end{array}$ & $\begin{array}{c}20-24 \\
3.3 \\
0\end{array}$ & $\begin{array}{l}\bar{x} \\
3.8 \\
0.7\end{array}$ \\
\hline $\begin{array}{l}\text { JUNIPERUS } \\
\text { QUERCUS } \\
\text { COmpositae } \\
\text { ARTEMISIA } \\
\text { Cheno-AmS } \\
\text { Gramineae } \\
\text { pollen sum }\end{array}$ & $\begin{array}{l}5 \\
14 \\
30.5 \\
7 \\
25 \\
8 \\
109\end{array}$ & $\begin{array}{l}5 \\
15 \\
23 \\
2 \\
22 \\
10 \\
130\end{array}$ & $\begin{array}{l}5 \\
14.5 \\
26.7 \\
4.5 \\
23.5 \\
9\end{array}$ & $\begin{array}{l}- \\
3.0 \\
18.0 \\
5.5 \\
31.0 \\
26.0 \\
201\end{array}$ & & $\begin{array}{l}52 \\
7 \\
20.5 \\
2 \\
8 \\
6 \\
211\end{array}$ & $\begin{array}{l}27 \\
15 \\
21 \\
4 \\
14 \\
3.5 \\
210\end{array}$ & $\begin{array}{l}59 \\
5 \\
16 \\
1.4 \\
4.3 \\
2.4 \\
210\end{array}$ & $\begin{array}{l}46 \\
9 \\
19.2 \\
2.5 \\
8.8 \\
4\end{array}$ \\
\hline
\end{tabular}

Table 3. Percentage values of dominant pollen types in stock tank and pollen trap samples. San Simon Sink. Lea county, New Mexico. The sample from Loving Salt Lake, Eddy Co.. New Mexico was taken below a $55 \mathrm{~cm}$ salt crust (Hafsten. 1961) and represents essentially modern conditions: This locality is $57 \mathrm{~km}$ west of San simon sink. a

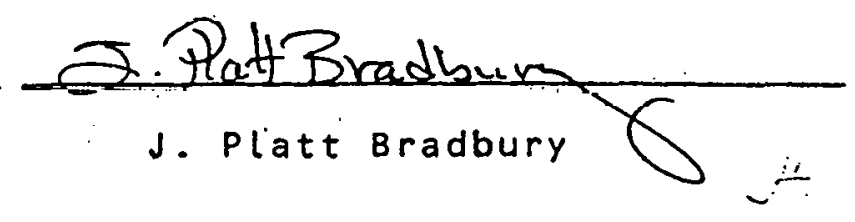




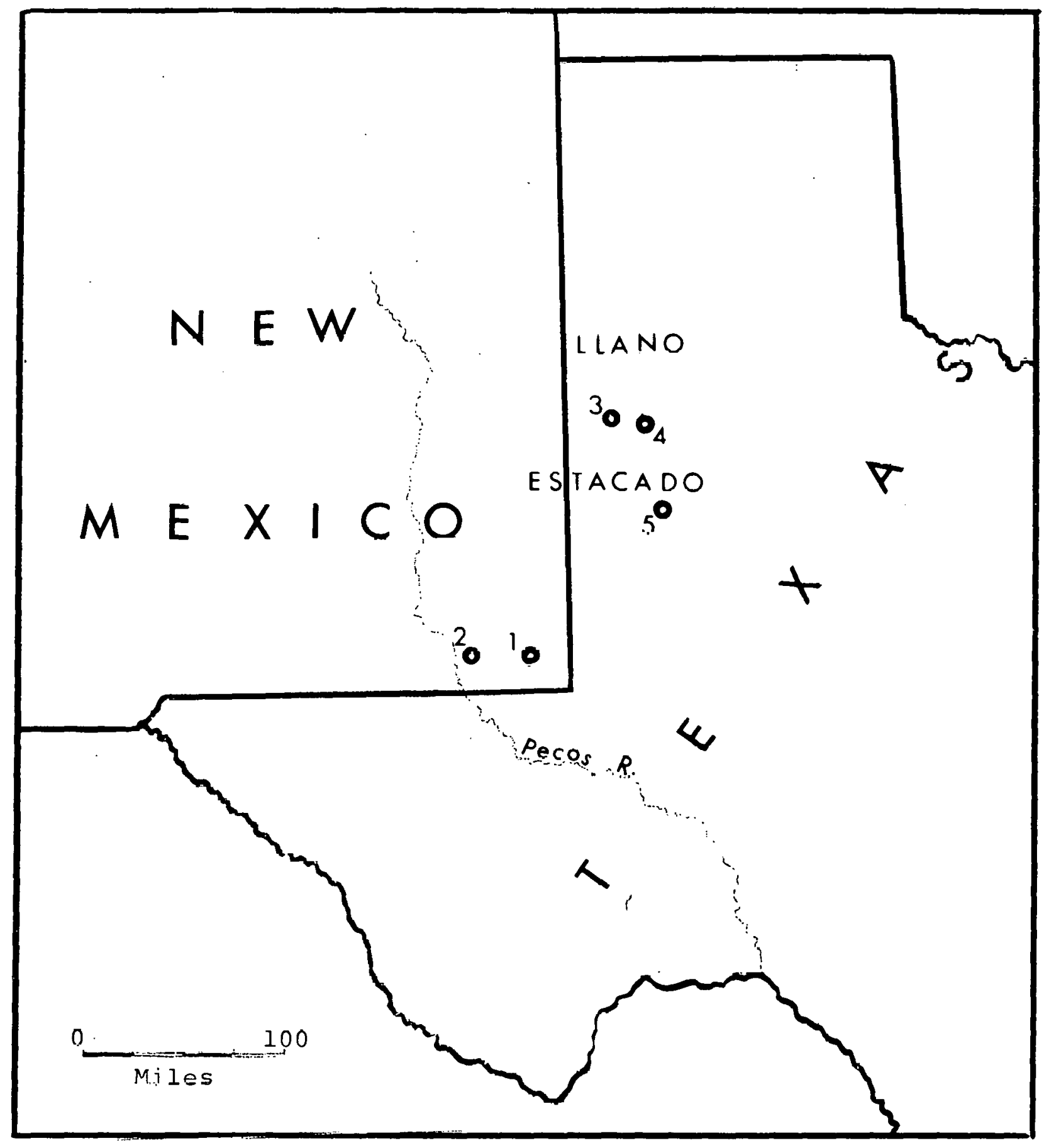

Figure 1. Index map of the Llano Estacado, modified from Appendex A. I. San Simun Sink, 2. Loving Salt Lake, 3. White Lake, 4. Illusion Lake,

5. Rich Lake.

$$
A-1-28
$$




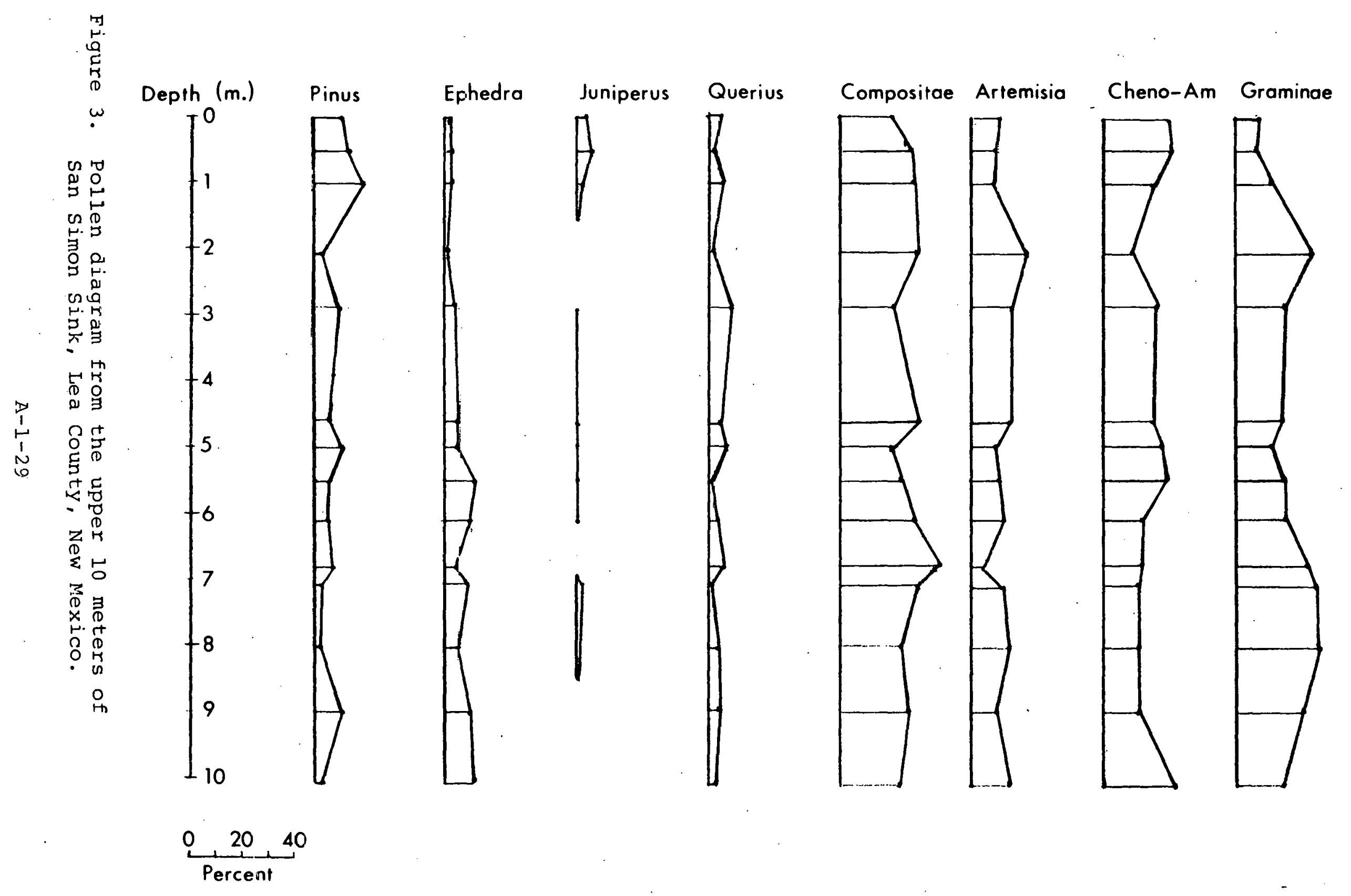


APPENDIX A-2

Radiocarbon Age Determination

Report of Analytical Work

by

- Krueger Enterprises, Inc. Geochron Laboratories Division 


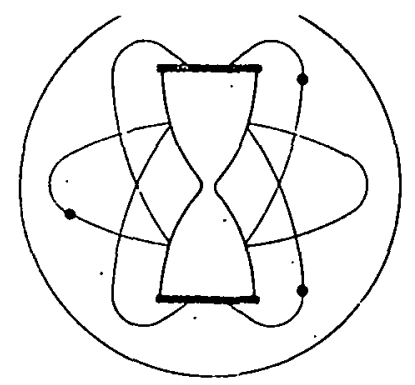

\section{KRUEGER ENTERPRISES, INC. GEOCHRON LABORATORIES DIVISION

Our Sample No. GX-5878

Date Received: 5 October 1978

Your Reference: letter of 2 October 1978

Date Reported: 19 December 1978

Submitted by: Roger $Y$. Anderson

Department of Geology

The University of New Mexico

Albuquerque, NE!N MEXICO 87131

Sandia Labs. Req. No. 13-4403

Sample Name: WIPP Site, N.Mexico. North side of San Simon Sink. Sample A. Shells.

$A G E=$

$20,570 \pm 540$ C-14 years B.P.

(C-13 corrected)

Description: Sample of gasicropod shells: Physa sp., Lymnaea sp., Helisoma sp.

Pretreatment: No pretreatment due to fragile nature of she17s.

\section{Comment:}

$\delta C_{P D B}^{13}=-4.2 \%$

Notes: This date is based upon the Libby half life (5570 years) for $C^{14}$. The error stated is $\pm 1 \sigma$ as judged by the analytical data alone. Our modern standard is $95 \%$ of the activity of N.B.S. Oxalic Acid.

The age is referenced to the year A.D. 1950. 


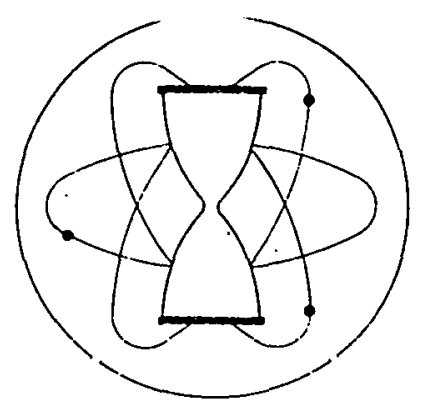

\section{KRUEGER ENTERPRISES, INC. \\ GEOCHRON LABORATORIES DIVISION}

24 BLACKSTONE STREET - CAMBRIDGE, MA. $02139 \cdot(617) \cdot 876.3691$

REPORT OF ANALYTICAL WORK

Our Sample No. GX-5879

Date Received: 5 October 1978

Your Reference: letter of 2 October 1978

Date Reported: 19 December 1978

Submitted by: Roger Y. Anderson

Department of Geology

The University of New Mexico

Albuquerque, NEH MEXICO 87131

Sand1a Labs. Req. No. 13-4403

Sample Name: WIPP Site, N.Mexico. North side of San Simon Sink. Sample B. Oogonia.

AGE $=-\quad$ Greater than $32,000 \mathrm{C}-14$ years B.P.

Description: Sample of Charophyte oogonia.

Pretreatment: No pretreatment due to fragile nature of shells.

\section{Comment:}

$\delta C_{P D B}^{13}=-3.7 \quad \%$

Notes: This date is based upon the Libby half life ( 5570 years) for $\mathrm{C}^{14}$. The error stated is $\pm 1 \sigma$ as judjed by the analytical data alone. Our modern standard is $95 \%$ of the activity of N.B.S. Oxalic Acid.

The age is referenced to the year A.D. 1950. 
APPENDIX B

Drilling and Testing Plan

by

R. 0 . Statler, 1133 


\section{Sandia Laboratories}

date: February 17, 1978

10: Distribution

from: R. D. Statler, 1133

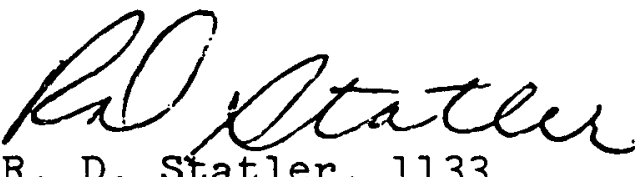

subject: WIPP Nos. 15 \& 17 Drilling Program, Schedule and Coring Plan

The exploratory holes designated as WIPP No. 15 and WIPP No. 17 are scheduled to be drilled in early spring 1978, commencing with WIPP No. 15 on approximately March 27 , 1978. WIPP No. 17 will be drilled immediately following WIPP No. 15.

The enclosed document describes the drilling plan, schedule and coring plan as they are presently understood.

PDSewara : $1135: \mathrm{jh}$

Distribution w/enclosures:

D. Davis, Jr., DOE/ALO, Albuquerque, N. M.

R. Y. Anderson, UNM, Geology Dept., Albuquerque, N. M.

J. W. Mercer, USGS/WRD, Albuquerque, N. M.

E. Shuter, USGS/WRD, Denver, Co.

R. E. Ashiock, F\&S, Las Vegas, NV

W. E. Cunningham, F\&S, Carlsbad, N. M. (3)

$1130 \mathrm{H}$. E. Viney

1135 P. D. Seward

1135 J. E. Magruder

5311 L. R. H1II

5311 D. W. Powers (3)

5311 S. J. Lambert

5311 Archives (2)

5342 J.W. McKiernan

9512 F. I. McFarling

1133 R. D. Statler (5) 
WIPP NOS. $15 \& 17$

DRILLING PLAN SCHFDULER.

AND TEST PLANS

\section{A. OBJECTIVE}

The exploratory holes designated as WIPP 15 and WIPP 17 will be drilled in early spring 1978. WIPP No. 15 is

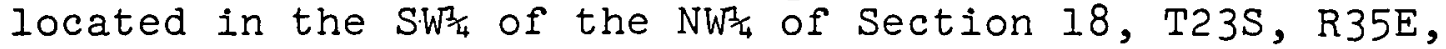
Lea County, New Mexico. WIPP No. 17 is located in the $\mathrm{NW}_{\frac{1}{4}}$ of the SW/ $\frac{1}{4}$ of Section 2, T23S, R34E, Lea County, New Mexico.

The purpose of these two holes will be to extract continuous small diameter core from the surface to the depth at which solid rock is encountered. It is not possible to predict the exact depth of either hole; hnwever, it. is felt that WIPP No. 15 will be on the order of 300 feet and WIPP No. 17 will be approximately 1000 feet.

WIPP No. 15 will be drilled in the portion of the San. Simon Swale which represents the most recent area of subsidence while WIPP No. 17 will be drilled in what is believed to be the center of the oldest (and deepest) subsidence. Cores from both holes will be analyzed by a team of geologists under the direction of Dr. Roger Anderson of the University of New Mexico. By using various agedating techniques, we hope to establish a dissolution rate within the San Simon Swale which may be used to infer future dissolution effects at the WIPP Los Medanos site.

B. SCHEDULE

1. Land and archaeological survey complete November, 1977.

2. Land use permits, drilling permits, land lease and archacological clearane iunplele Feurudry, 1978.

3. FAO on Fienix and Scisson placed February, $197 \dot{8}$.

4. Drilling contract awarded March, 1978.

5. Access roads and drilling pads complete by March 15 , 1978 .

6. Notice to proceed to drilling contractor by March 20, 1978 (WIPF NO. 15).

7. Expect spudding of hole to be approximately March 27, 1978.

8. Estimate hole completion by March 31, 1978.

9.. Demobilize from WIPP No. 15 and move to WIPP No. 17 by Apri1 3, 1978 .

10. Expect spudding of WIPP No. 17 by April 3, 1978.

11. Estimate hole completion by April 11, 1978.

Note: If core recovery is considered incomplete on either hole, the services of USGS/WRD Drilling, Sampling and Testing Techniques Project Group 
may be used to obtain core in the missing formations. In this instance, complete recovery will be delayed until June, 1978 due to their scheduling.

C. ORGANIZATION

Technical direction will originate within Sandia Division 5311 under Dennis Powers. Scientific consultation will be provided by the University of New Mexico under Dr. Roger Anderson, Field Operations, managed by R. D. Statler, Sandia Division 1133, w1ll be conducted by W. E. Cunningham, Fenlx \& Scisson Driliing Contract and associated support service contracts will be let and administered by F\&S as arranged for by Federal Agency Order through Nevada Operations Offlce, DOE.

Identification of marker bids, core logging and other geologic interpretations will be provided as appropriate by Dr. Roger Anderson, UNM, Jerry Mercer, USGS/WRD and Joe Gonzales, F\&S.

Administrative assistance and logistical support of Sandia programs will be provided by P. D. Seward and J. E. Magruder, Sandia Division 1135.

D. FIELD OPERATIONS

1. Sites selected and state antiquities permit applied for WIPP No. 17 site, and lease negotiated with owner of WIPP No. 15 site. Land surveys made on both sites. Land survey should consist of a plot showing township, range, section and distance in feet to the closest section boundary. Plot should show route of a $25 \mathrm{ft}$. wide access road and layout of 150 feet $X 150$ feei drill pad (may not be required on WIPP No. 15 as access route exists and native soll compaction may be adequate to accomodate rig and associated equipment).

2. Archaeological survey taken in conjunction with land surveys for filing with the land use permit application for WIPP No, 17 .

3. Temporary land use permit application for WIPP No. 17 filed with the State of New Mexico for access road and drill pad.

4. File "Notice of Intention to Drill Exploratory Well" with N. M. State Engineer. 
5. Award drill contract, purchase long lead time items. Negotiate other pertinent contracts as appropriate (mud, coring, logging, etc.).

6. Award dirt contract, construct minimum access road and drill pad (WIPP No. 17 may require stabilization of 6" caliche base, WIPP No. 15 should require repairs only to existing access road). Metal mud and water tanks to be provided by contractor.

7. Move in $r i g$ and associated equipment for continuous core extraction:

8. Dry punch hole and extract first core to a depth of $7^{\prime} \pm$.

9. P1ck up 3-1/4" $\times$ 2-1/4" diamond core bit with eplit barrel and rotary to 32 feet at appropriate speed to assure continuous recovery using fresh water as drilling fluld. If additives are required to drilling fluid, particular care must be taken to avoid materials that contain vegetative matter or pollens. If possible, samples of any additives should be made available to the duty geologist for field analysis prior to mixing with the dri17ing fluid. Samples of drilling fluids will be taken twice a day using clean sample bottles. Samples will be returned to Albuquerque per the instrintitens of the duty geologist for analysis.

10. Pick up 8-3/4" b1t and ream hole to 32 feet. Set $7 "$ 0 . D. used casing as conductor pipe at 32 feet cemented to surface. Install appropriate well head equipment to provide blow out protection:

11. Pick up 3-1/4" X 2-1/4" diamond core bit and rotary to T.D. cxtracting continuous cure. If continuous core is not attained particular note should be made of the missing Intervals and the physical properties of any formation, if attainable. If it is determined that recovery from those formations would be questionable using standard coring procedures in an additional nearby hole, the USGS/WRD Drlliling, Sampling and 'l'esting Techniques Project Group will be called upon to provide their expertise and special equipment to gain core from the missing intervals.

12. If aquifers are encountered, contractor should be prepared to case and cement these formations in accordance with the State Engineer's specifications. 
13. Upon completion of coring operation, condition hole, log with USGS/WRD Geophysical Logging Equipment and plug to surface using a grout mixture of $50 \%$ Class "C" cement / 50\% flyash with fresh water. A dispersant or friction reducing agent to improve flow characteristics of grout during pumping may be used. A silica sand (about 5\% by weight) may be added to reduce loss to the formation.

14. Rig down and move to next hole or release rig. Actual procedures to be followed during coring operations will be published as an appendix to this document . 
WIPP NOS. $\quad 15 \& 17$

APPENDIX A: CORE AND CORE HANDLING PROGRAM

Cores with $21 / 4 "$ nominal diameter are to be taken continuously from ground surface to the T.D. of both holes. It is recognized that formations may be encountered which are soft and/or rubblized; therefore, particular attention must be paid to rate of rotation, penetration and drilling fluid properties to assure as complete a recovery as possible.

A split core barrel is to be utilized to ease the removal of core from the barrel and to lessen the possibility of damaging or mixing core components.

A duty geologist will $\mathrm{log}$ and measure core as it is removed from core barrel. Core will then be sealed within plastic sleeving and packaged in standard cardboard boxes. If core is soft and/or badly rubblized additional cushioning material will be placed around core within box. Boxes will then be marked with hole identity and core interval. Core will then be carefully loaded in a transport vehicle by contractor personnel as supervised by duty geologist, and taken to core storage in Carlsbad for subsequent shipment to Albuquerque.

A coring record should be kept showing: date and tour, sequence of core interval, depth of interval, footage of core recovered and percentage. If significant intervals are missing, the depth and interval of missing core should be recorded as well as any determinable physical properties of the formation. Rig operating conditions such as RPM, weight on bit, circulating pressure should also be kept.

For sake of consistency a routine has been established for handling and marking core at the drill pad as follows:

1. Coring contractor and roustabouts will lay barrel down and open barrel. The duty geologist will photograph core and supervise removal from core barrel and placement in troughs in the order they come out of barrel for inspection and measurement. Troughs are marked orange or red indicating top end and black indicating down direction.

2. If core is suitable for marking, each major piece should be marked with a water proof black ink arrow pointing in the direction the hole is advancing. If core is not suitable for marking, the above is to be marked on sleeving using an indelible, water proof black marking pen. 
3. Log, identify and measure all core pleces, express to closest I/loth of foot. Note: All depth measurements are from the top side of the Kelly Bushing unless otherwise specified.

4. Move troughs to core shed and separate into appropriate lengths. Sleeve and seal and insert into boxes. Tape boxes and mark outside of box with hole identity and depths of core interval.

5. Transport boxed core to core storage taking particular care in handing and delivery to avold core damage. 
APPENDIX C

Hole History

compiled by

R.D. Statler, 1133, and P.D. Seward, 1134 
penIX a sCISSON. INC.

HOLE HISTORY DATA

DATE: JUIY 11, 1978

\begin{tabular}{|c|c|c|}
\hline HOLE NO.I WIPP \#15 & w. O. NO.: & \\
\hline user, Sandia Lab & Exploratory & \\
\hline Location New Mexico & county, Lea & AREA: \\
\hline \multicolumn{3}{|c|}{ SURFACE COORDINATES: $2426^{\prime} \mathrm{FNL}, 1973^{\prime} \mathrm{FWL}$, SeC. 18, T23S, R35E } \\
\hline GROUND ELEVATION: $3269.34^{\prime}$ & PAD ELEVATION: & TOP CASING ELEVATION: \\
\hline RIG ON LOCATION: & SPUDDED: $3-8-78$ & COMPLETED: \\
\hline
\end{tabular}

CirCulatimg media: Air to $13.2^{\prime}$, mud to $810.5^{\prime}$

MAIN RIG \& CONTRACTOR

\begin{tabular}{|c|c|c|c|c|c|}
\hline \multicolumn{3}{|c|}{ BORE HOLE RECORD } & & & \\
\hline FROM & TO & SIZE & I.D. & WT.FT. & WALL \\
\hline $0^{\prime}$ & $13.25^{\circ}$ & $8-3 / 4^{\prime \prime}$ & $6.366^{\prime \prime}$ & 23\# & \\
\hline $13.25^{\prime}$ & $592^{\prime}$ & $6-1 / 8^{\prime \prime}$ & $4^{\prime \prime}$ & $11.3 \#$ & \\
\hline $592^{\prime}$ & $810.5^{\prime}$ & $3.975^{\prime \prime}$ & & & \\
\hline & & & & & \\
\hline & & & & & \\
\hline & & & & & \\
\hline
\end{tabular}

TOTAL DEPTH: $810.5^{\circ} \mathrm{GL}$ AVERAGE MANEREL DEPTH:

NO. OF COMPRESSORS \& CAPACITY:

\section{CASING RECORD}

\begin{tabular}{|l|l|r|r|l|}
\hline GRADE & CPL'G. & FROM & \multicolumn{1}{|c|}{ TO } & CU. FT. CMT. \\
\hline $\mathrm{J}-55$ & & $0^{\prime}$ & $13.25^{\prime}$ & None \\
\hline HW & & $0^{\prime}$ & $555^{\prime}$ & None \\
\hline & & & & \\
\hline & & & & \\
\hline
\end{tabular}

JUNK \& PLUGS LEFT IN HOLE:

\begin{tabular}{|l|l|}
\hline SURVEYS PAGE: & CORING PAGE: 3 \\
\hline
\end{tabular}

FROM REFERENCE ELEVATION P

LOGGING DATA: USGS LOgS

i BOTTOM HOLE COORDINATES:

REFERENCE:

\begin{tabular}{|c|c|c|c|c|c|c|c|}
\hline \\
\hline & & \multicolumn{2}{|c|}{ RIGS USED } & \multicolumn{2}{|c|}{ (Site Prep Rigs } & \multicolumn{2}{|l|}{ *) } \\
\hline NIS NO. & NAME & TYPE & CLASS & $\begin{array}{l}\text { DAYS } \\
\text { OPERATING } \\
\end{array}$ & $\begin{array}{l}\text { SECURED } \\
\text { W CREW }\end{array}$ & $\begin{array}{l}\text { SECURED } \\
\text { W/OCREW } \\
\end{array}$ & $\begin{array}{l}\text { TOTALDAYS } \\
\text { ON LOC. }\end{array}$ \\
\hline 3625 & Boyles Bros. & Faliing 2000 & & 8.21 & - & 19.08 & 27.29 \\
\hline & & & & & & & \\
\hline & & & & & & & \\
\hline & & . & & & & & \\
\hline & & & & • & & & \\
\hline & & & & & & & \\
\hline REMARK & - Site Prep Iten & & & & & & \\
\hline
\end{tabular}


Woved In Boyles Bros. r1g \#3625 and rigged up. Cut core 非 thru \#11 from 0" to 116" using a 2-3/8" 0.D. $x 18^{\prime \prime}$ long split sample spoon. The spoon was driven with a 160" drive hamer using a $30^{\prime \prime}$ stroke. Opened hole to 5-7/8" using air. Made up a Pitcher core barrel with 4-3/4" x 2-3/4" core bit. Cut core 非2 and 非13 from 116" to 159"

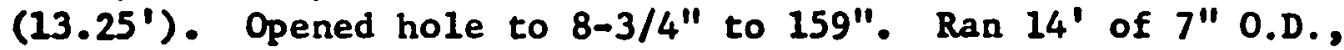
J-55 casing to 159". Worked days only.

3-9-78 Mixed up a fresh water mud. Made up a wire line core barrel with a split 1nner barrel. A 3.975" $x$ 2-1/8" diamond core bit was used. -Cut core 非14 thru 非2 from 13.25' to $29.35^{\prime}$. Made up 4" rock bit, -opened core hole and drilled 4" hole from $29.35^{\prime}$ to $75^{\prime}$. Cut core \#21 from 75' to $80^{\prime}$.

3-10-78 Contimed cutting core $\# 21$ from $80^{\prime}$ to $85.3^{\prime}$. Cut core $\# 22$ thru - 抽36 from $85.3^{\prime}$ to $162.2^{\prime}$.

3-13-78 Rig secured from 3-10-78 to 3-13-78. Cut core 非7 thru 非6 from $162.2^{\prime}$ to $206.6^{\prime}$.

3-14-78 Cut core $\$ 47$ thru \#59 from 206.6' to 298.2'.

3-15-78 Cut core \#60 thru 非6 from 298.2' to $426.2^{\prime}$.

3-16-78 Cut core 非 thru 非7 from 426.2' to 493.2'. Cleaned out 20' of fill at $426.2^{\prime}, 9^{\prime}$ of fill at $443.2^{\prime}$ and $12^{\prime}$ of fill at $446.2^{\prime}$. Raised viscosity of mud at $489.2^{\prime}$ and circulated hole, viscosity In returns was 47 seconds.

3-17-78 Cleaned out bridges and 20' of fill to bottom. Cut core 非8 thru $=\$ 93$ from 493.2'. Ran USGS logs.

:3-20-78 Rig secured from 3-17-78 to 3-20-78. Cleaned out $15^{\prime}$ of fill, losing

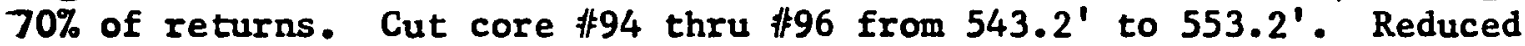
: and viscosity from 75 to 50 seconds and cut loss circulation to

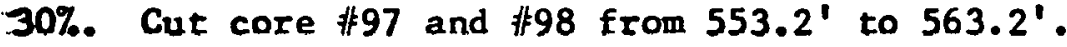

Cleaned out $3^{\prime}$ of fill and cut core $\# 99$ thru $⿰ ⿰ 三 丨 ⿰ 丨 三 101$ from $563.2^{\prime}$ to 577. $2^{\prime}$. Changed out to tungsten carbide b1t at 566.2'.

3-22-78 Cleaned out bridge at 557' and $3^{\prime}$ of fill on bottom. Cut core \#102 chrie \#106 from $577.2^{\prime}$ to $600.2^{\prime}$.

3-23-78 Cleaned out $2^{\prime}$ of $f 111$ and cut core $⿰ 10107$ thru $\$ 110$ from $600.2^{\prime}$ to $635.2^{\prime}$. Lost approximately 100 barrels of mud.

3-24-78 Cut core \#111 thru 1114 from $635.2^{\prime}$ to $657.2^{\prime}$.

3-27-78 R1g secured from 3-24-78 to 7-27-78. Washed $80^{\circ}$ to bottom and cut core \$15 thru \#118 from 657.2'. to 678.2'. Lost 90 barrels of mad.

3-28-78 Fluid level at 60'. Cleaned out $2^{\prime}$ of f111 and cut core 非19 thru $\$ 122$ from 678.2' to 704.7'. Lost 90 barrels of mud. 
3-29-78 Cleaned out $1.6^{\prime}$ of f1ll and cut core \#123 thru 127 from 704.7' to $745.2^{\prime}$. Iost 60 barrels of mud.

3-30-78 Cleaned out $2^{\prime}$ of fill and cut core \#128 thru \#132 from 745.2' to 781.7'. Lost 30 barrels of mud.

3-31-78 Cleaned out $1^{\prime}$ of fill and cut core \#133 thru \#137 from 781.7' to 810.5'. Changed out to diamond core bit.

4-3-78 Rig secured from 3-31-78 to 4-3-78. Conditioned mud for 1ogging. Ran USGS logs.

4-4-78 Opened hole to 6-1/8" to 592', conditioned and to run casing. Ran $4 \frac{1}{2} "$ O.D., 11.3"k, HW casing with two 1/16" slots, 1 ' long on opposite sides of the casing as follows:

No. Jolnts

$\begin{aligned} 1 & \text { Blank casing } \\ 3 & \text { Slotted casing } \\ 15 & \text { Blank casing }\end{aligned}$

Depth

$$
\begin{array}{r}
555^{\prime}-540^{\prime} \\
540^{\prime}-445^{\prime} \\
445^{\prime}-0^{\prime}
\end{array}
$$

The bottom of joint 非 1 was belled in and a pipe clamp was welded on top of joint 非19 and landed on the $7^{\prime \prime} 0.0$. surface casing. A locked cap was welded on top of the $4 \frac{3}{2} "$ O.D. collar of joint 非19. Rigged. down. Hole suspended. 


\section{Core No,}

1

2

3

5

6

7

8

9

10

11

12

13

14

15

16

17

18

19

20

21

22

23

24

25

26

27

28

29

30

31

32

33

34

35

36

37

38

39

40

41

42

43

44

45

46

47

48

49

50

51
Interval

0" -12 1"

$12^{\prime \prime}$ - 26"

26" - 34"

$34^{\prime \prime}-48^{\prime \prime}$

$48^{\prime \prime}$ - $60^{\prime \prime}$

$60^{\prime \prime}$ - $66^{\prime \prime}$

$66^{\prime \prime}$ - 78"

78" - 84"

84" - 96"

96" - 108'

108" - 116"

$116^{\prime \prime}$ - 145"

$145^{\prime \prime}$ - 159"

$13.25^{\prime}-15.70^{\prime}$

$15.70^{\prime}-18.00^{\prime}$

$18.00^{\circ}-22.55^{\prime}$

$22.55^{\prime}-23.85^{\prime}$

$23.85^{\prime}-26.35^{\prime}$

$26.35^{\prime}-28.35^{\prime}$

$28.35^{\prime}-29.35^{\prime}$

$75^{\prime}-85,3^{\prime}$

$85.3^{\prime}-90.2$

$90.2^{\prime}-95.2^{\prime}$

$95.2^{\prime} \quad-102.7^{\prime}$

$102.7-108.2^{\prime}$

$108.2^{\prime}-113.2^{\prime}$

$113.2^{\prime}-118.2^{\circ}$

$118.2^{\prime}-123.2^{\prime}$

$123.2^{\prime}-128.2^{\prime}$

$128.2^{\prime}-133.2^{\prime}$

$133.2^{\prime}-138.2^{\prime}$

$138.2^{\prime}-143.2^{\prime}$

$143.2^{\prime}-149.2^{\prime}$

$149.2^{\prime}-153.2^{\prime}$

$153.2^{\prime}-158.2^{\prime}$

$158.2^{\prime}-162.2^{\prime}$

$162.2^{\circ}-164.2^{\circ}$

$164.2^{\prime}-168.2^{\circ}$

$168.2^{\prime}-173.2^{\prime}$

$173.2^{\prime}-178.2^{\prime}$

$178.2^{\circ}-183.2^{\circ}$

$183.2^{\prime}-188.2^{\prime}$

$188.2^{\prime}-193.2^{\prime}$

$193.2^{\prime}-198.2^{\prime}$

$198.2^{\prime}-203.2^{\prime}$

203.2' -206.6'

$206.6^{\prime}-213.2^{\prime}$

213.2' $-218.2^{\prime}$

$218.2^{\prime}-226.3^{\prime}$

$226.3^{\prime}-231.4^{\prime}$

$231.4^{\prime}-238.2^{\prime}$

\section{Cored}

$12^{\prime \prime}$
$14^{\prime \prime}$
$8^{\prime \prime}$

$14^{\prime \prime}$

$12^{\prime \prime}$

$12^{\prime \prime}$

6"

$22^{11}$

$12^{\prime \prime}$

8"

29"1

$14^{n}$

$2.45^{\prime}$

$2.30^{\circ}$

$4.55^{\prime}$

$1.30^{\prime}$

$2.50^{\prime}$

$2.00^{\prime}$

$1.00^{\prime}$

$10.3^{\prime}$

$4.9^{\prime}$

$5.0^{\prime}$

$7.5^{\circ}$

$5.5^{\prime}$

5. $0^{\prime}$

$5.0^{\circ}$

$5.0^{\circ}$

$5.0^{\circ}$

$5.0^{\circ}$

$5.0^{\prime}$

$5.0^{\prime}$

$6.0^{\prime}$

4. $0^{\prime}$

$5.0^{\prime}$

$4.0^{\prime}$

$2.0^{\prime}$

4. $0^{\prime}$

$5.0^{\circ}$

$5.0^{\prime}$

5. $0^{\circ}$

5. $0^{\prime}$

$5.0^{\circ}$

$5.0^{\prime}$

$5.0^{\prime}$

$3.4^{\prime}$

$6.6^{\prime}$

$5.0^{\prime}$

$8.1^{\prime}$

$5.1^{\prime}$

$6.8^{\prime}$
Recovered \% Recovery

$12^{\prime \prime}$
$12^{\prime \prime}$
$6^{\prime \prime}$
$8^{\prime \prime}$
$9^{\prime \prime}$
$6^{\prime \prime}$
$8^{\prime \prime}$
$6^{\prime \prime}$
$12^{\prime \prime}$
$12^{\prime \prime}$
$7{ }^{\prime \prime}$
$29^{\prime \prime}$
$14^{\prime \prime}$
$0^{\prime}$

2.6'

$2.25^{\prime}$

$0.9^{\circ}$

2. $0^{\prime}$

2.15'

$10.3^{\prime}$

4.81

$4.65^{\circ}$

$7.65^{\prime}$

$5.5^{\prime}$

4.91

$5.15^{1}$

$5.1^{\prime}$

$5.0^{\prime}$

4.90

5.11

$5.0^{\prime}$

$6.1^{\prime}$

$3.7^{\prime}$

$4.2^{\prime}$

$2.7^{\prime}$

$3.5^{\prime}$

$3.9^{\circ}$

$4.9^{\circ}$

$3.9^{\prime}$

$6.3^{\circ}$

$5.1^{\prime}$

$5.0^{\prime}$

$5.2^{\circ}$

$5.0^{\prime}$

$3.2^{\circ}$

$6.6^{1}$

4.98

$8.3^{\prime}$

$5.0^{\prime}$

$6.8^{\prime}$
100

86

75

57

75

100

67

100

100

100

88

66

100

113

49

.69

80

215

100

98

93

102

100

98

103

102

100

98

102

100

102

93

84

68

175

98

98

78

126

102

100

104

100

94

100

100

103

98

100 


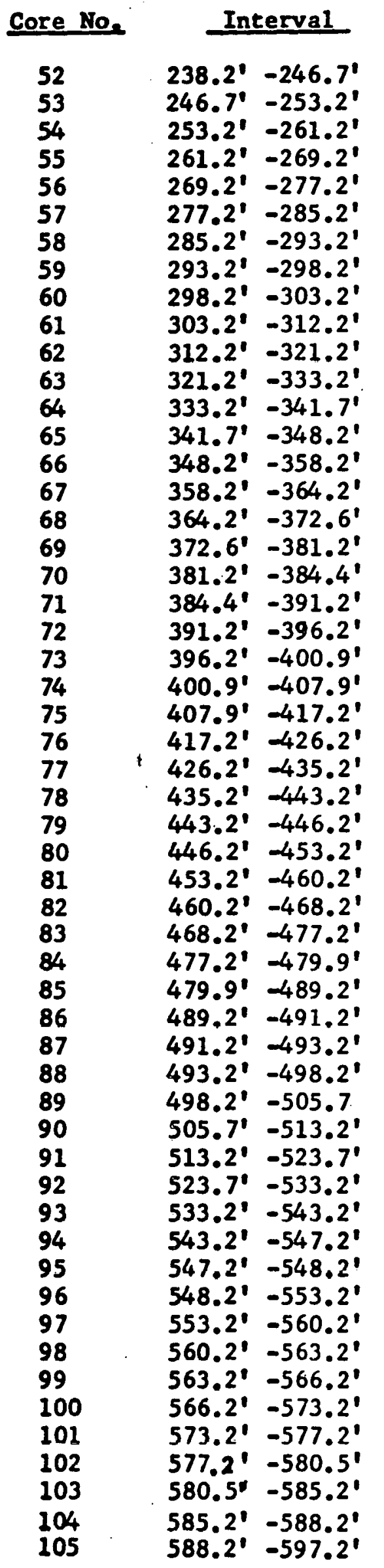

\section{Cored}

$8.5^{\prime}$

$6.5^{\prime}$

$8.0^{\prime}$

$8.0^{\prime}$

$8.0^{\prime}$

8. $0^{\prime}$

$8.0^{\prime}$

$5.0^{\prime}$

$5.0^{\prime}$

$9.0^{\prime}$

$9.0^{\prime}$

$12.0^{\prime}$

$8.5^{\prime}$

$6.5^{\prime}$

10.0'

$6.0^{\prime}$

$8.4^{\prime}$

$8.6^{\prime}$

$3.2^{\prime}$

$6.8^{\prime}$

$5.0^{\prime}$

$4.7^{\prime}$

$7.0^{\circ}$

$9.3^{\prime}$

$9.0^{\prime}$

$9.0^{\prime}$

$8.0^{\prime}$

$3.0^{\prime}$

$7.0^{\prime}$

7.0

$8.0^{\prime}$

9.0'

$2.7^{\prime}$

$9.3^{\circ}$

$2.0^{\prime}$

$2.0^{\prime}$

$5.0^{\prime}$

$7.5^{\prime}$

$7.5^{\prime}$

10.5'

$9.5^{\prime}$

$10.0^{\prime}$

$4.0^{\prime}$

$1.0^{\prime}$

$5.0^{\prime}$

$7.0^{\prime}$

$3.0^{\prime}$

$3.0^{\prime}$

$7.0^{\prime}$

$5.0^{\prime}$

$3.3^{\prime}$

$4.7^{1}$

$3.0^{\prime}$
Recovered

$8.5^{\prime}$

$6.5^{\prime}$

$8.0^{\prime}$

$7.9^{\prime}$

$8.1^{\prime}$

$8.0^{\prime}$

$8.0^{\circ}$

$5.0^{\prime}$

$4.5^{\circ}$

$9.5^{\circ}$

$9.0^{\prime}$

$9.9^{\prime}$

$8.5^{\prime}$

$6.5^{\circ}$

$10.0^{\prime}$

$6.0^{\prime}$

$7.6^{\prime}$

$6.2^{\prime}$

$4.2^{\prime}$

$6.5^{\prime}$

$3.9^{\prime}$

$4.5^{\prime}$

$7.0^{\prime}$

$9.2^{\prime}$

$8.6^{\prime}$

9.11

$3.0^{\prime}$

3.0

7. 0

$8.0^{\circ}$

$8.0^{\prime}$

$9.5^{\prime}$

$2.0^{\circ}$

$1.0^{\prime}$

$2.6^{\circ}$

$2.0^{\prime}$

$5.0^{\circ}$

$6.9^{\prime}$

$7.3^{\prime}$

$8.6^{\prime}$

$8.0^{\prime}$

$8.5^{\prime}$

$2.6^{\circ}$

$0.0^{\prime}$

$6.0^{\circ}$

$7.0^{\circ}$

$3.0^{\prime}$

$2.0^{\circ}$

$6.4^{\circ}$

$4.0^{\prime}$

4. $0^{\prime}$

$3.3^{\prime}$

$3.5^{\prime}$

$8.5^{\prime}$
7. Recovery'

100

100

100

99

101

100

100

100

90

104

100

83

100

100

100

100

91

72

131

96

78

96

100

99

96

101

38

100

100

114

100

106

74

11

130

100

100

92

97

82

84

85

65

120

100

100

67

91

75

121

70

117 
FENIX \& SCISSON, INC.

\section{HOLE HISTORY DATA}

DATE: 7-10-78

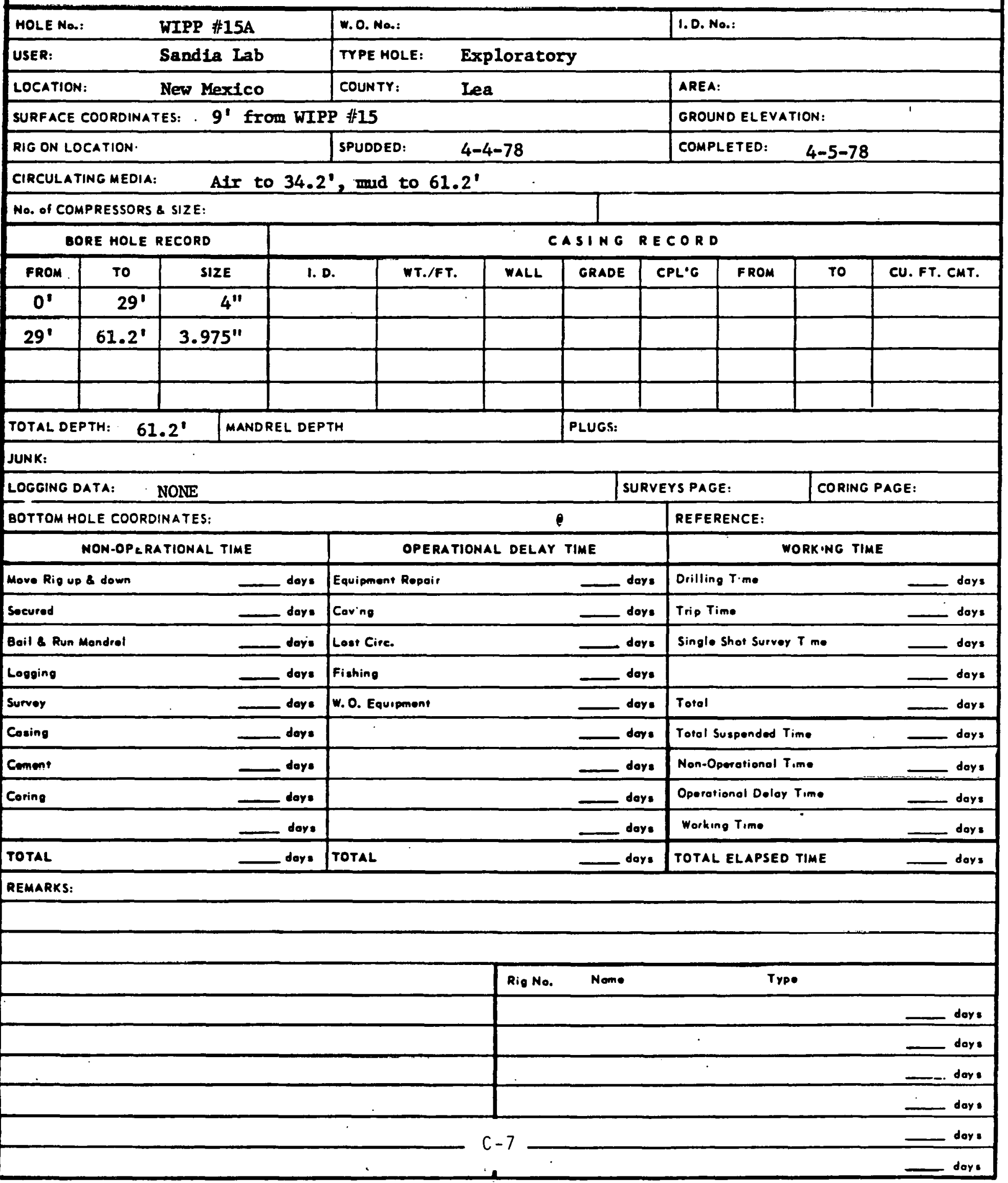


4-4-78 Moved Boyles rig $\$ 3625,9^{\prime}$ from the original hole to recover cores, lost from $29^{\circ}$ to $75^{\circ}$. Rigged up and drilled $4^{\prime \prime}$ hole from $0^{\prime}$ to $29^{\prime}$ wth air. Kigiged up alr hammer.

4-5-78 Attempted to drive split sample spoon with no results. Rigged up wire line core barrel with a split inner barrel and a 3.975" diamond b1t. Cut core $\left.\right|_{1}$ from $29^{\prime}$ to $34.2^{\prime}$ using air, no recovery. Cut corc 非 thru \#5 from $34.2^{\prime}$ to $61.2^{\prime}$ using mud. Rigged down. Hole cómílezed.

\section{CORE RECORD}

Core No,

1

2

3

4

5
Interva1- Ft

$$
29=34.2
$$

$34.2-37.8$

$37.8-43.2$

$43.2-32.0$

$52.0-61.2$
Cored-Ft

5.2

3.6

5.4

8.8

9.2
Recovered-Ft \%Recovery

0
3.6
5.4
0.0
9.2

n

100

100

100

100 
APPENDIX D

LOGS

compiled by

S-E. Shaffer, 4511 


$$
\text { WIPP } 15 \text { Logs }^{1}
$$

\begin{tabular}{|c|c|c|c|c|}
\hline Log & Company & $\begin{array}{c}\text { Top of } \\
\text { Logged } \\
\text { Interval } \\
\text { (feet) } \\
\end{array}$ & $\begin{array}{r}\text { Bottom } \\
\text { Logged } \\
\text { Interval } \\
\text { (feet) }\end{array}$ & Date \\
\hline Density & U.S.G.S. & 6 & 806 & $4-3-78$ \\
\hline Garma & U.S.G.S。 & 6 & 806 & $4-3-78$ \\
\hline Neutron & U.S.G.S. & 8 & 806 & $4-3-78$ \\
\hline
\end{tabular}

loriginal data is retained in Sandia WIPP Central File, Division 4542, Sandia National Laboratories, Albuquerque, NAM 87185.

${ }^{2}$ Depths measured from ground surfaces elevation officially 3269.34 feet. above MSL. 


\section{Distribution:}

U.S. Department of Energy, Headquarters

Office of Nuclear Waste Management

Washington, DC 20545

Larry Harmon, Project Coordinator (WIPP)

Colin A. Heath, Director, Division of Waste Isolation (2)

U.S. Department of Energy, Albuquerque Operations

P.0. Box 5400

Albuquerque, NM 87185

J. M. McGough, Manager, WIPP Project Office (2)

D. Jackson, Director, Public Affairs Division

U.S. Department of Energy

Carlsbad WIPP Project Office

Room 113, Federal Building

Carlsbad, NM 88220

U.S. Department of Energy

c/o Battelle Office of Nuclear Waste I solation

$505 \mathrm{King}$ Avenue

Columbus, $\mathrm{OH} 43201$

$$
\text { Jeff } 0 \text {. Neff }
$$

Battelle Memorial Institute

Office of Nuclear Waste I solation

505 King Avenue

Columbus, $\mathrm{OH} \quad 43201$

S. Goldsmith, Manager

ONWI Library

Battelle Memorial Institute

Project Management Division

505 King Avenue

Columbus, $\mathrm{OH} 43201$

Neal Carter, General Manager

Westinghouse Electric Corporation

P. 0. Box 40039

Albuquerque, NM 87196

R. K. Brown

$R$. Jones (TSC)

Bechtel National, Inc。

Fifty Beale Street

P. 0. Box 3965

San Francisco, CA 94119

D. L. Ledbetter

Dale Roberts 
National Academy of Sciences, WIPP Panel:

Frank L. Parker, Chairman

Department of Environmental and Water Resources Engineering

Vanderbilt University

Nashville, TN 37235

Konrad B. Krauskopf, Vice Chairman

Department of Geology

Stanford University

Stanford, CA 94305

Kar 1 P. Cohen, Member

Consultant

928 N. California Avenue

Palo Alto, CA 94303

Neville G. W. Cook, Member

Dept. Of Material Sciences and Engineering

University of California at Berkeley

Hearst Mining Building, \#320

Bcrkeley, CA 94720

Fred M. Ernsberger, Member

Glass Research Center

PPG Industries, Inc.

Box 11472

Pittsburgh, PA 15238

Harold L. James, Member

1617 Washington St.

Port. Townsend, WA 98368

Richard R. Parizek, Member

Department of Hydrogeology

Pennsylvania State University

University Park. PA 168ח?

D'Arcy A. Shock, Member

233 Virginia

Ponca City, OK 74601

John W. Winchester, Member

Department of Oceanography

Florida State University

Tallahassee, FL 32306

John T. Holloway

Senior Staff Officer

2101 Constitution Avenue, NW

Washington, DC 20418 
WIPP Public Reading Room

Atomic Museum, Kirtl and East AFB

Albuquerque, NM 87185

Attn: Ms. Gwynn Schreiner

WIPP Public Reading Room

Carlsbad Municipal Library

101 S. Hallagueno St.

Carlsbad, NM 88220

Attn: Lee Hubbard, Head Librarian

Thomas Brannigan Library

106 W. Hadley St.

Las Cruces, NM 88001

Attn: Don Dresp, Head Librarian

Roswell Public Library

301 N. Pennsylvania Avenue

Roswe 11, NM 88201

Attn: Ms. Nancy Langston

Hobbs Public Library

509 N. Ship St.

Hobbs, NM 88248

Ms. Marcia Lewis, Librarian

State of New Mexico

Environmental Evaluation Group

320 Marcy Street

P.0. Box 968

Santa Fe, NM 87503

Robert H. Nei17, Director (2)

NM Department of Energy \& Minerals

P.0. Box 2770

Santa Fe, NM 87501

Larry Kehoe, Secretary

Kasey LaP lante, Librarian

New Mexico State Geologist

P. 0. Box 2860

Santa Fe, NM 87501

Emery C. Arnold

New Mexico State Library

P.0. Box 1629

Santa Fe, NM 87503

Ms. Ingrid Vollenhofer

New Mexico Tech

Martin Speer Memorial Library

Campus Street

Socorro, NM 87801 
Zimmerman Library

University of New Mexico

A Tbuquerque, NM 87131

Ms. ATice Clark

USGS, Water Resources Division

P. 0. Box 26659

Albuquerque, NM

J. W. Mercer

87125

USGS, Conservation Division

Office of Mining \& Resource Evaluation

P. 0. Box 506

Carlsbad, NM 88220

C. B. John

USGS, Conservation Division

P. 0. Box 1857

Roswe11, NM 88201

W. Melton

USGS, Special Projects Branch

Federal Center, Bldg. 25

Denver, C0 80225

R. P. Snyder (2)

New Mexico Bureau of Mines and Mineral Resources

Socorro, NM 87801

F. E. Kottlowski. Director (2)

Klạus Kuhn

Gesellschaft fuer Strahlen-und

Umweltforschung MBH Muenchien

Institut fuer Tieflagerung

Berliner Strasse 2

3392 Clausthal-Zellerfeld

Federal Republic of Germany

K'1 aus Eckart Maass

Hahn-Meitner-Institut fuer Kernforschung

Glienicker Strasse 100

1000 Berlin 39

Federai Republic of Germany

Michael Langer

Bundesanstalt fuer Geowissenschaften und Rohstoffe

Postfach 510153

3000 Hannover 51

Federal Republic of Germany 
Reinhard Kraemer

Kernforschung Karlsruhe

Postfach 3640

$7500 \mathrm{Karl}$ sruhe

Federal Republic of Germany

Helmut Rothemeyer

Physikalisch-Technische Bundes anstalt

Bundesalle 100

3300 Braunschweig

Federal Republic of Germany

Rolf-Peter Randl

Bundesministerium fuer Forschung und Technologie

Postfach 200706

5300 Bonn 2

Federal Republic of Germany

Fenix \& Scisson, Inc.

3170 W. Sahara Avenue

Spanish Oaks D-12

Las Vegas, NV 89102

J. A. Cross

Fenix \& Scisson, Inc.

401 N. Canal Street

Carlsbad, NM 88220

Matt Wilson

Gayle Pawloski, L-222

Geologist CSDP

Lawrence Livermore Laboratory

Livermore, CA 94550

Roger Y. Anderson (5)

Dept. of Gcology

University of New Mexico

Albuquerque, NM 87131

J. Platt Bradbury (5)

Paleontology \& Stratigraphy Branch

U.S. Geological Survey

Denver, CO 80225.

William Sliter, Chief

Paleontology \& Stratigraphy Branch

M.S. 970

U.S. Geological Survey

Reston, VA 20092 
U.S. Nuclear Regulatory Commission (3)

Division of Waste Management

Mail Stop 69755

$\frac{\text { Washington, DC } 20555}{\text { Attn: J. Martin, M. Bell, H. Miller }}$

Sandia Internal:

1133 R. D. Statler

1135 P. D. Seward

3141 L. J. Erickson (5)

3151 W. L. Garner, For: DOE/TIC (Unlimited Release)

3154-3 C. H. Dalin, For: DOE/TIC (25)

4500 E. H. Beckner

4510 W. D. Weart

4511 D. W. Powers

4511 L. J. Barrows

4511 D. D. Gonzalez

4511 S. J. Lambert

4511 D. L. Robinson

4511 S-E Shaffer

4540 M. L. Kramm

4542 Sandia WIPP Central Files (12)

8214 M. A. Pound 


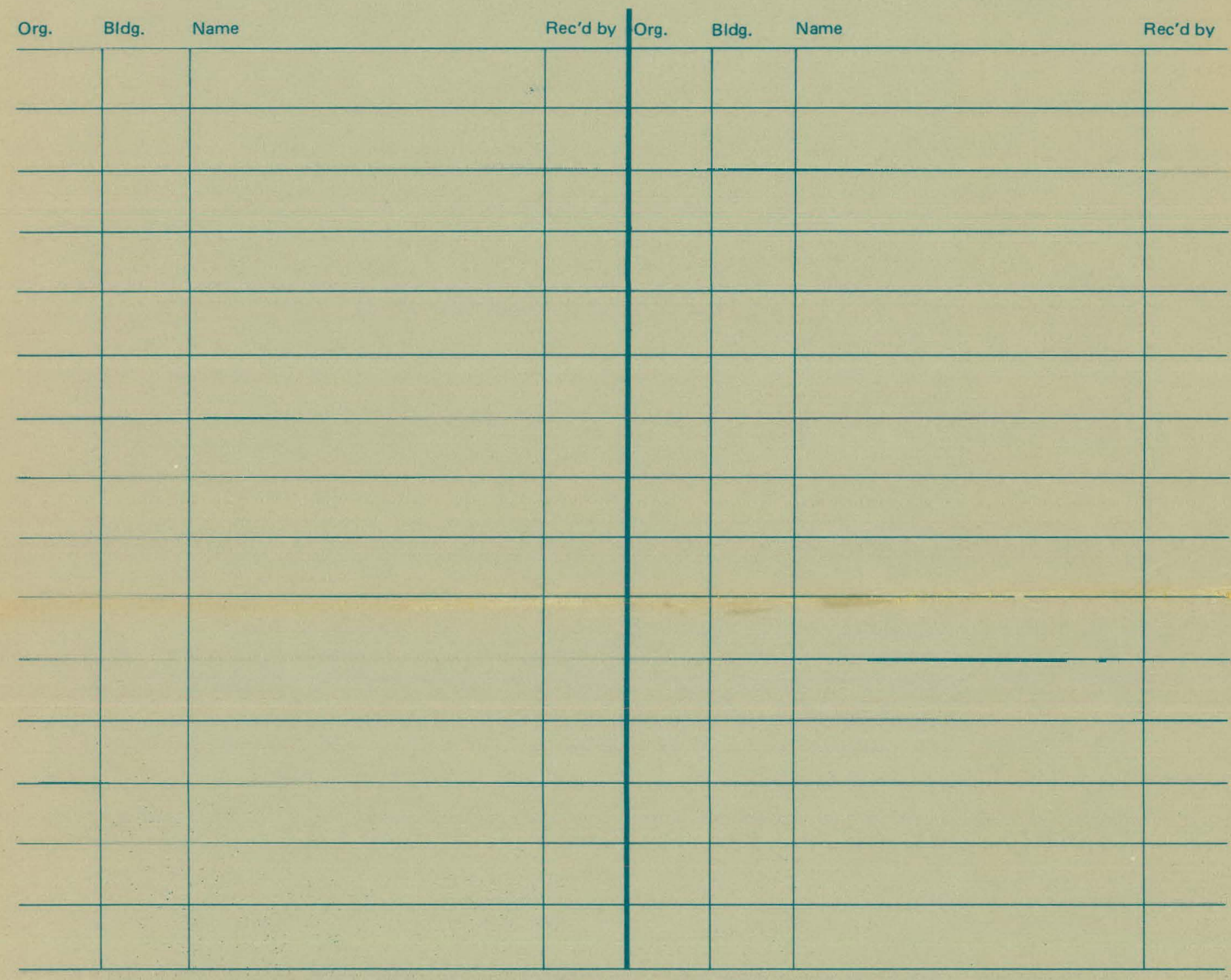

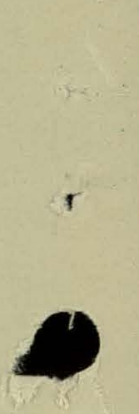

